\title{
4. MIOCENE TO PLEISTOCENE RADIOLARIAN BIOSTRATIGRAPHY OF NORTH PACIFIC SITES 881, 884, 885, 886, AND $887^{1}$
}

\author{
Joseph J. Morley ${ }^{2}$ and Catherine Nigrini ${ }^{3}$
}

\begin{abstract}
Ocean Drilling Program Leg 145 recovered sediments from seven sites in the North Pacific, all of which contained radiolarians. The northernmost sites, Site 884 on the eastern flank of the Detroit Seamount (Emperor Chain) and Site 887 on the PattonMurray Seamount Platform (Gulf of Alaska), contained the oldest radiolarian-bearing sediments of lower Miocene age. Radiolarian sediments from the central (885 and 886) and western (881) North Pacific sites ranged in age from late Miocene to Pleistocene.

Based on their stratigraphic potential, we selected 39 radiolarian species and determined their abundance and preservation (entire radiolarian assemblage) in Leg 145 sediments. The high-latitude North Pacific Miocene through Pleistocene radiolarian population is described and classified in detail, with the identification of a new species, Dictyophimus bullatus, and subspecies, Lychnocanoma nipponica sakaii. This research provides the critical stratigraphic link in the previously disconnected Miocene and Pliocene siliceous faunal sequences from the western and eastern margins of the North Pacific. Because of the nearly complete sections recovered at the Leg 145 sites, many of which contain excellent paleomagnetic records, it is possible to estimate with a fairly high degree of accuracy the age of specific faunal events in the various regions of the North Pacific. The results of this comprehensive survey of the temporal and spatial distribution of radiolarians in high-latitude North Pacific sediments are compared with those reported previously from the North Pacific and other ocean regions, thereby refining and expanding the siliceous faunal stratigraphy.
\end{abstract}

\section{INTRODUCTION}

Ocean Drilling Program (ODP) Leg 145 traversed the North Pacific, occupying 7 sites and recovering sediments from 25 holes. Because of time constraints, this study is confined to an examination of the siliceous fauna in 7 holes at only 5 of these sites (Table 1; Fig. 1). The radiolarian fauna in sediments from the other two sites (Sites 882 and 883 ) should be similar to that reported here for Site 884 because of the close proximity of these three sites to one another.

Several previous legs have drilled in North Pacific waters. Investigators (Foreman, 1973; 1975; Ling, 1980; Reynolds, 1980; Sakai, 1980; Schaaf, 1981; Wolfart, 1981; Morley 1985) have reported on the presence, abundance, and ranges of radiolarians recovered from mid-latitude North Pacific sites during Deep Sea Drilling Project (DSDP) Legs 20, 32, 55, 56, 57, 62, 63, and 86. Additional papers (Kling, 1973; Ling, 1973) have described the siliceous fauna from high-latitude North Pacific sites associated with DSDP Legs 18 and 19 . Only the sediments collected during Leg 86 , however, were retrieved using the advanced hydraulic piston corer (APC), which drastically improves recovery as it greatly minimizes sediment disturbance. Leg 145 marked the first time that ODP had drilled in the high-latitude North Pacific and the first time a scientific drill ship had entered these North Pacific latitudes since 1970.

Radiolarians occur in sediments from all five sites examined as part of this study. The northernmost sites from the western (Site 884) and eastern (Site 887) Pacific contain radiolarians of early Miocene

\footnotetext{
${ }^{1}$ Rea, D.K., Basov, I.A., Scholl, D.W., and Allan, J.F. (Eds.), 1995. Proc. ODP, Sci. Results, 145: College Station, TX (Ocean Drilling Program).

${ }^{2} 32$ West End Avenue, Westwood, NJ 07675, U.S.A.

${ }^{3} 510$ Papyrus Drive, La Habra Heights, CA 90631, U.S.A
}

Table 1. Coordinates and water depths of Leg 145 holes analyzed in this study.

\begin{tabular}{cccc}
\hline Hole & Latitude & Longitude & $\begin{array}{c}\text { Water depth } \\
(\mathrm{m})\end{array}$ \\
\hline $881 \mathrm{~A}$ & $47^{\circ} 06.14^{\prime} \mathrm{N}$ & $161^{\circ} 29.49^{\prime}, \mathrm{E}$ & 5531.1 \\
$881 \mathrm{C}$ & $47^{\circ} 06.13^{\prime} \mathrm{N}$ & $161^{\circ} 29.49^{\prime} \mathrm{E}$ & 5530.8 \\
$884 \mathrm{~B}$ & $51^{\circ} 27.03^{\prime} \mathrm{N}$ & $168^{\circ} 20.23^{\prime} \mathrm{E}$ & 3824.8 \\
$885 \mathrm{~A}$ & $44^{\circ} 41.30^{\prime} \mathrm{N}$ & $168^{\circ} 16.32^{\prime}, \mathrm{W}$ & 5708.5 \\
$886 \mathrm{C}$ & $44^{\circ} 41.38^{\prime}, \mathrm{N}$ & $168^{\circ} 14.40^{\prime} \mathrm{W}$ & 5713.3 \\
$887 \mathrm{~A}$ & $54^{\circ} 21.92^{\prime} \mathrm{N}$ & $148^{\circ} 26.77^{\prime}, \mathrm{W}$ & 3631.2 \\
$887 \mathrm{C}$ & $54^{\circ} 21.93^{\prime} \mathrm{N}$ & $148^{\circ} 26.78^{\prime} \mathrm{W}$ & 3633.6 \\
\hline
\end{tabular}

to Pleistocene age. The siliceous faunal assemblage in sediments from the southern three sites (Sites 881,885 , and 886) range in age from late Miocene to Pleistocene.

Site 881 was situated in the abyssal plain underlying waters of the central portion of the western subarctic gyre. Site 884 sampled sediments from the Meiji Drift along the eastern flank of the Detroit Seamount. Sites 885 and 886 recovered sediments from the central North Pacific at the southern margin of the subarctic gyre. The platform surrounding the Patton-Murray Seamounts in the Gulf of Alaska was the location of the northernmost site (887) drilled during Leg 145.

The continuous coring techniques employed during Leg 145, the nearly complete sections recovered, the excellent magnetic reversal record, and the spatial distribution across the North Pacific of the five sites examined in this study make it possible to construct a detailed inventory of the Miocene through Pleistocene radiolarian population in the high-latitude North Pacific. The excellent magnetostratigraphy acquired for most of these sites presents us with the opportunity to refine and revise the age of species' first (FO) and last (LO) occurrences and compare our results with those reported from the Japanese and California margins as well as from the low-latitude Pacific and Indian oceans. 


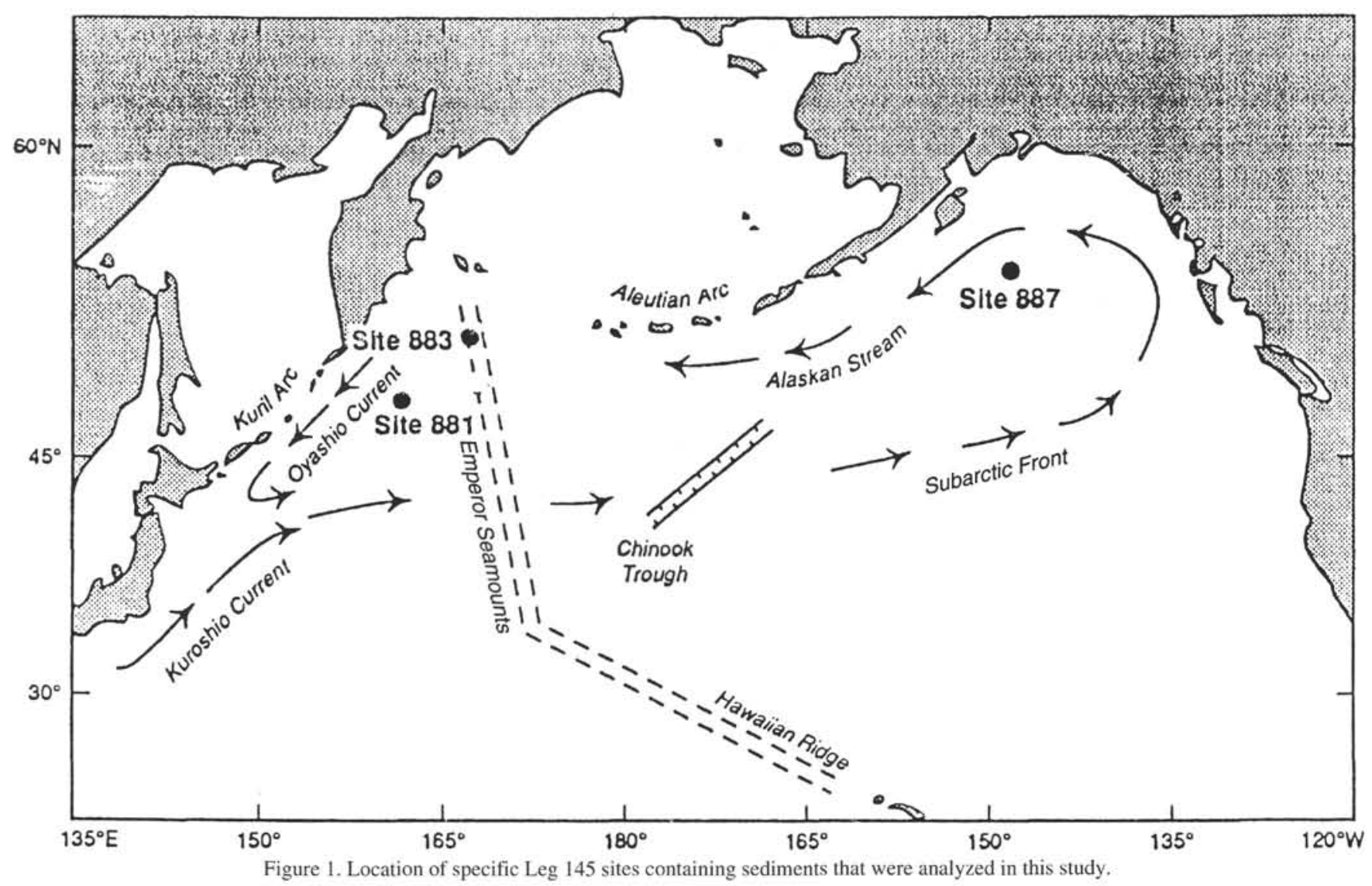

\section{METHODS}

\section{Sampling, Sample Preparation, and Census Counting}

As many as six samples per core were taken for biostratigraphic analysis. All samples were dried, weighed, disaggregated with the aid of hydrogen peroxide and sieved at $63 \mu \mathrm{m}$. In most cases, the residue remaining on the sieve was randomly settled on slides following the technique described by Moore (1973). Strewn slides were also made for much of the upper Miocene through lower Pliocene sediment sequence from the five sites so as to reduce the flood of large-sized diatoms, which masked the radiolarians in many samples throughout this time interval.

Abundance values presented on range charts (Tables 2-6) are based on calculations of the number of radiolarians per gram of raw sample. The relative abundance of radiolarians in each sample is determined using the dry sample weight, the area of the beaker in which the sample is randomly settled, and the number of radiolarians per area of slide. Abbreviations for radiolarian abundances are $\mathrm{R}=$ rare (0-4999 radiolarians/gram), $\mathrm{F}=$ few (5000-9999 radiolarians/gram), $\mathrm{C}=$ common $(10000-24,999$ radiolarians/gram), and $\mathrm{A}=$ abundant ( $>25,000$ radiolarians/gram).

Radiolarian preservation is indicated for all samples examined on range charts (Tables 2-6) with abbreviations defined as follows: G (good), indicating little sign of dissolution of radiolarians with only minor fragmentation; $\mathrm{M}$ (moderate), signifying evidence of moderate dissolution of radiolarians with obvious fragmentation; and $\mathrm{P}$ (poor), denoting a high degree of dissolution of radiolarians with few complete specimens.

The relative abundance of individual species given in Tables 2 through 6 is based on systematic examination of a minimum of 500 radiolarians per sample with abbreviations defined as follows: $\mathrm{R}=$ rare ( $2-5$ individual per 500$) ; \mathrm{F}=$ few (6-20 individuals per 500); C $=$ common $(>20$ individuals per 500$) ;+=1$ individual per $500 ; \mathrm{P}=$ present (present in sample, but outside of area counted); $-=$ specimens sought but not found ++ = older fauna reworked in sediment sample; and ? = dubious identification.

\section{Species Selection}

Several criteria were used in the selection of the 39 radiolarian species for this study. All had been identified in at least one of the hundreds of strewn slides prepared during Leg 145. Many of the 39 species are components of various radiolarian zonations constructed for North Pacific siliceous sediments. Most of the selected species also were described by other investigators in their reports of radiolarians in North Pacific sediments recovered during earlier ocean drilling legs (Foreman, 1973, 1975; Kling, 1973; Ling, 1973, Reynolds, 1980; Sakai, 1980; Schaaf, 1981; Wolfart, 1981; Morley, 1985). Some species were also chosen because of their reported dominance in Japanese and Californian siliceous sequences of Miocene age (Nakaseko and Sugano, 1973; Weaver et al., 1981; Funayama, 1988). For the most part, the species selected for this study are relatively easy to identify, with most having distinct stratigraphic ranges.

\section{Zonation}

No radiolarian zonation has yet been proposed for high-latitude $\left(>42^{\circ} \mathrm{N}\right)$ North Pacific sediments, mainly because of the scarcity of recovered long, continuous siliceous sequences from this region. Sediments from sites drilled in this region during DSDP Legs 18 and 19 were discontinuously sampled and lacked magnetostratigraphy. 
Table 2. Census counts for stratigraphically important species in Holes 881C and 881D.

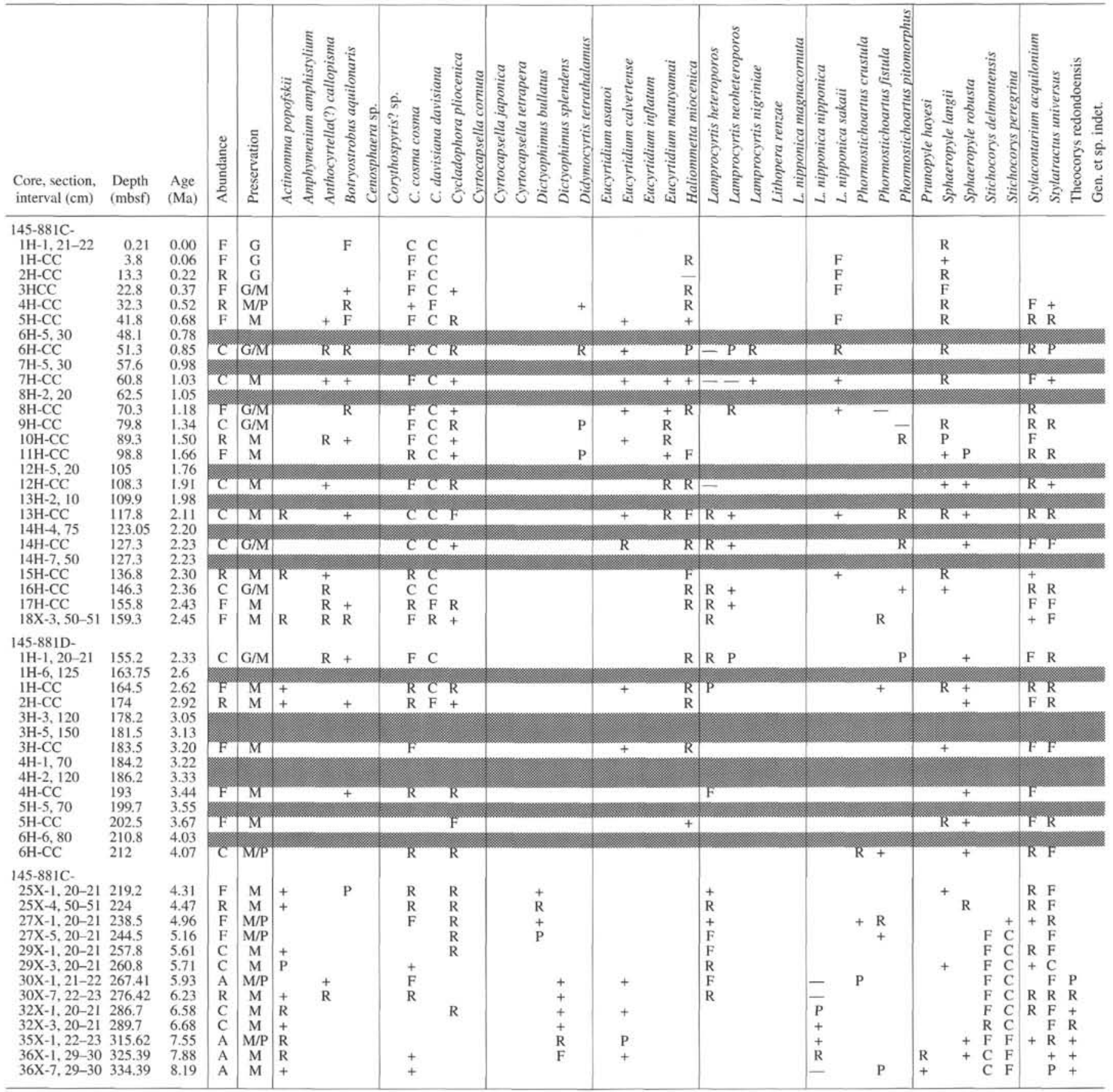

Notes: Shading indicates level of identified magnetic event. See "Sampling, Sample Preparation, and Census Counting" in "Methods" section for explanation of entries.

The first continuous sections drilled with the advanced hydraulic piston corer (APC) in the North Pacific at latitudes higher than $40^{\circ} \mathrm{N}$ were taken during DSDP Leg 86 . The stratigraphic ranges of most radiolarians of Pliocene through Pleistocene age recovered during Leg 86 (Morley, 1985), as well as other mid-latitude legs (i.e., Leg 56 [Sakai, 1980]), appeared to fit the radiolarian zonation proposed by Foreman (1975). Miocene radiolarian sequences from the mid-latitude North Pacific seemed to conform to the low and mid-latitude zonation developed by Riedel and Sanfilippo (1970, 1971, 1978). Because of the occurrence in Leg 57 sediments of numerous high-latitude ra- diolarian species whose ranges were in agreement with only the Pliocene and Pleistocene portion (Foreman, 1975) of the North Pacific zonal scheme, Reynolds (1980) constructed a new radiolarian zonation for Miocene siliceous sequences from the mid-latitude northwest Pacific. This zonation, however, is not as widely accepted as that put forth by Foreman (1975).

Siliceous faunal material from the high-latitude North Pacific examined during this study does not neatly conform to these North $\mathrm{Pa}$ cific radiolarian zonations. The radiolarian species with their associated ranges in sediment sequences younger than 2 Ma corre- 
Table 3. Census counts for stratigraphically important species in Hole 884B.

\begin{tabular}{|c|c|c|c|c|c|c|c|c|c|c|c|c|}
\hline $\begin{array}{l}\text { Core, section, } \\
\text { interval }(\mathrm{cm})\end{array}$ & $\begin{array}{l}\text { Depth } \\
\text { (mbsf) }\end{array}$ & $\begin{array}{l}\text { Age } \\
(\mathrm{Ma})\end{array}$ & 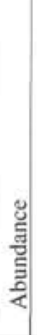 & 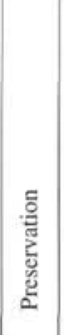 & 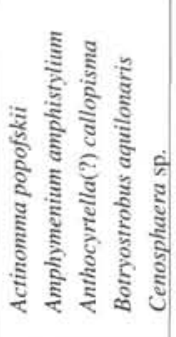 & 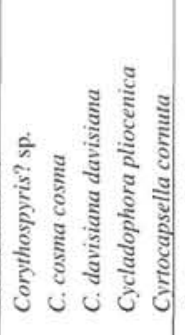 & 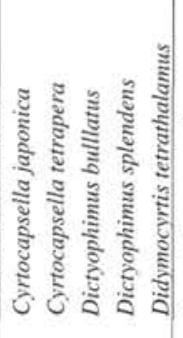 & 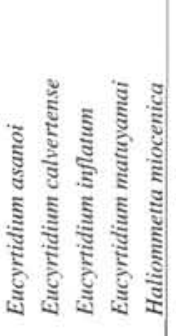 & 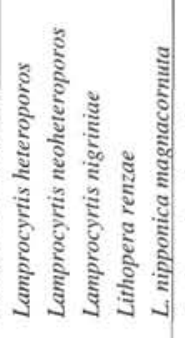 & 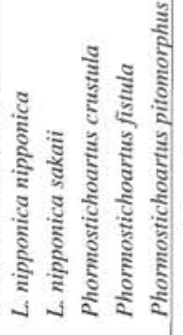 & 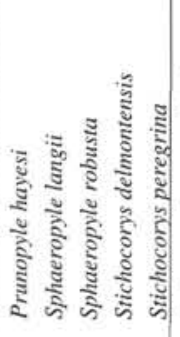 & 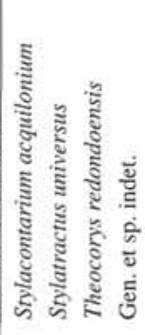 \\
\hline $\begin{array}{l}145-884 \mathrm{~B}- \\
1 \mathrm{H}-1,20-2 \mathrm{I} \\
1 \mathrm{H}-4,135-136 \\
2 \mathrm{H}-5,135-136 \\
3 \mathrm{H}-5,135-136 \\
4 \mathrm{H}-5,135-136 \\
5 \mathrm{H}-5,135-136\end{array}$ & $\begin{array}{c}0.2 \\
5.85 \\
13.85 \\
23.35 \\
32.85 \\
42.35\end{array}$ & $\begin{array}{l}0.00 \\
0.11 \\
0.25 \\
0.43 \\
0.60 \\
0.78\end{array}$ & $\begin{array}{l}\mathrm{C} \\
\mathrm{F} \\
\mathrm{C} \\
\mathrm{C} \\
\mathrm{F} \\
\mathrm{C}\end{array}$ & $\begin{array}{l}\mathrm{G} \\
\mathrm{G} \\
\mathrm{G} \\
\mathrm{G} \\
\mathrm{G} \\
\mathrm{G}\end{array}$ & $\begin{array}{l}\mathrm{C} \\
\mathrm{C} \\
\mathrm{C}\end{array}$ & $\begin{array}{ll}\mathrm{C} & \mathrm{F} \\
\mathrm{F} & \mathrm{C} \\
\mathrm{F} & \mathrm{C} \\
\mathrm{C} & \mathrm{C} \\
\mathrm{C} & \mathrm{C} \\
\mathrm{C} & \mathrm{C}\end{array}$ & & $\begin{array}{l}+ \\
+ \\
R \\
R \\
R\end{array}$ & & $\begin{array}{l}+ \\
\mathrm{C} \\
\mathrm{F} \\
\mathrm{P} \\
\mathrm{P}\end{array}$ & $\begin{array}{l}\mathrm{F} \\
\mathrm{R} \\
\mathrm{R} \\
\mathrm{F} \\
\mathrm{F} \\
\mathrm{F}\end{array}$ & $\begin{array}{ll}\mathrm{P} & - \\
\mathrm{P} & \mathrm{P} \\
\mathrm{F} & \mathrm{R}\end{array}$ \\
\hline $\begin{array}{l}5 \mathrm{H}-5,150 \\
6 \mathrm{H}-5,135-136\end{array}$ & $\begin{array}{l}42.5 \\
51.85\end{array}$ & $\begin{array}{l}0.78 \\
0.93\end{array}$ & $\mathrm{R}$ & G & & & & & & & & \\
\hline $\begin{array}{l}6 \mathrm{H}-5,135-136 \\
7 \mathrm{H}-1,60\end{array}$ & $\begin{array}{l}51.85 \\
54.6\end{array}$ & $\begin{array}{l}0.93 \\
0.98\end{array}$ & & & & $\mathrm{~F} C$ & & $\mathrm{R}$ & & R & $\mathrm{R}$ & $\mathrm{F}+$ \\
\hline $7 \mathrm{H}-3,90$ & 59.4 & 1.05 & & & & & & & & & & \\
\hline $7 \mathrm{H}-5,135-136$ & 61.35 & 1.10 & $C$ & $\mathrm{G} / \mathrm{M}$ & & $C \mathrm{C}$ & & + & & & F & \\
\hline $8 \mathrm{H}-5,135-136$ & 70.85 & 1.33 & $\mathrm{~F}$ & G & & C C & & $\mathrm{R} R$ & & + & + & $\mathrm{F}$ \\
\hline $9 \mathrm{H}-4,135-136$ & 78.85 & 1.53 & $\mathrm{R}$ & M & $\mathrm{R}$ & C C & & & & & & $F$ \\
\hline $\begin{array}{l}10 \mathrm{H}-\mathrm{CC} \\
12 \mathrm{X}-1,68-69\end{array}$ & $\begin{array}{l}86.3 \\
87.98\end{array}$ & $\begin{array}{l}1.72 \\
1.76\end{array}$ & $\begin{array}{l}\mathrm{R} \\
\mathrm{F}\end{array}$ & $\begin{array}{c}\mathrm{G} / \mathrm{M} \\
\mathrm{M}\end{array}$ & $\mathrm{F}$ & $\begin{array}{ll}\mathrm{F} & \mathrm{C} \\
\mathrm{C} & \mathrm{C}\end{array}$ & & $\begin{array}{r}+ \\
+\quad \mathrm{R}\end{array}$ & +- & + & $\begin{array}{l}\mathrm{R}-\overline{\mathrm{P}} \\
+\end{array}$ & $\begin{array}{ll}\mathrm{R} & \mathrm{F} \\
\mathrm{R} & \mathrm{F}\end{array}$ \\
\hline $13 \mathrm{X}-3,60$ & 96.9 & 1.98 & & & & & & & & & & \\
\hline $13 X-3,134-135$ & 97.64 & 2.00 & $F$ & M & R & $C \mathrm{C}$ & & $-R$ & - & - & R P & R \\
\hline $\begin{array}{l}14 X-3,110 \\
14 X-4,70\end{array}$ & $\begin{array}{l}107.1 \\
108.2\end{array}$ & $\begin{array}{l}2.20 \\
2.23\end{array}$ & & & & & & & & & & \\
\hline $14 X-5,133-134$ & 110.33 & 2.29 & $\mathrm{~F}$ & $\mathrm{M}$ & & $\mathrm{C} C$ & & $\mathrm{R}$ & & & P & R R \\
\hline $15 X-5,135-136$ & 119.95 & 2.55 & $\mathrm{~F}$ & $\mathrm{M}$ & $\mathrm{P}$ & C C & & $\mathrm{P}$ & -- & - & $+\mathrm{P}$ & $\mathrm{F} R$ \\
\hline $15 X-7,30$ & 121.9 & 2.6 & & & & & & & & & & \\
\hline $16 \times-5,135-136$ & 129.55 & 2.73 & $\mathrm{R}$ & $M / P$ & & $\mathrm{R} F$ & & + & & & & \\
\hline $17 X-5,135-136$ & 139.15 & $\begin{array}{l}2.90 \\
3.05\end{array}$ & $\mathrm{R}$ & $\mathrm{M} / \mathrm{P}$ & + & $\mathrm{F} F \mathrm{R}$ & & $\mathrm{R}$. & -- & & & F R \\
\hline $\begin{array}{l}18 X-4,60 \\
18 X-5,135-136\end{array}$ & $\begin{array}{l}148.1 \\
148.85\end{array}$ & $\begin{array}{l}3.05 \\
3.06\end{array}$ & $\mathrm{R}$ & $\mathrm{M}$ & + & $F$ & & & & + & R & F R \\
\hline $19 X-1,125$ & 152.35 & 3.13 & & & & & & & & & & \\
\hline $19 X-5,135-136$ & 158.45 & 3.21 & $\mathrm{R}$ & M & R & + & & $\mathrm{R}$ & & & + & F R \\
\hline $19 X-6,100$ & 159.6 & 3.22 & & & & & & & & & & \\
\hline $21 X-5,135-136$ & 177.85 & 3.53 & F & M & $\mathrm{R}$ & F & & & & & & $\mathrm{R}$ \\
\hline $21 X-6,120$ & $\begin{array}{l}179.2 \\
19711\end{array}$ & $\begin{array}{l}3.55 \\
3.76\end{array}$ & $\mathrm{R}$ & 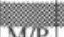 & R & & & & & & & \\
\hline $\begin{array}{l}23 X-5,131-132 \\
25 X-5,135-136\end{array}$ & $\begin{array}{l}197.11 \\
216.45\end{array}$ & $\begin{array}{l}3.10 \\
3.99\end{array}$ & $\begin{array}{l}\mathrm{R} \\
\mathrm{R}\end{array}$ & $\begin{array}{c}\mathrm{M} / \mathrm{P} \\
\mathrm{M}\end{array}$ & $\begin{array}{l}R \\
+\end{array}$ & $\begin{array}{l}\mathrm{F} \\
\mathrm{F}\end{array}$ & & $\mathrm{R}$ & + & & + & $\begin{array}{ll}\mathrm{F} & \mathrm{R} \\
\mathrm{R} & \mathrm{F}\end{array}$ \\
\hline $26 \mathrm{X}-1,95$ & 219.65 & 4.03 & & & & & & & & & & \\
\hline $26 \times-4,100$ & 224.2 & $\begin{array}{l}4.13 \\
4.33\end{array}$ & R & $\mathrm{M} / \mathrm{P}$ & & $F$ & & & F & & & \\
\hline $\begin{array}{l}27 X-5,135-136 \\
29 X-1,135-136\end{array}$ & $\begin{array}{l}235.75 \\
248.95\end{array}$ & $\begin{array}{l}4.33 \\
4.56\end{array}$ & $\mathrm{~F}$ & $\mathrm{M}$ & & + & & & & & $+\stackrel{+}{R}$ & $\begin{array}{ll}+ & F \\
F & F\end{array}$ \\
\hline $29 \times-4,0$ & 252.1 & 4.61 & & & & & & & & & & \\
\hline $\begin{array}{l}30 \mathrm{X}-1,110 \\
30 \times-7,50\end{array}$ & $\begin{array}{l}258.4 \\
266.8\end{array}$ & $\begin{array}{l}4.69 \\
4.81\end{array}$ & & & & & & & & & & \\
\hline $31 X-5,135-136$ & 274.35 & 4.99 & $F$ & $M$ & & F & + & & $\mathrm{R}$ & & + & $R++$ \\
\hline $31 X-1,70$ & 276.7 & 5.05 & & & & & & & & & & \\
\hline $33 \times-4,135-136$ & 292.15 & 5.34 & R & M & & F & & & & & & \\
\hline $35 \mathrm{X}-1,135-136$ & 307.05 & 5.62 & $\mathrm{~F}$ & M & & $\mathrm{R}$ & $\mathrm{R}$ & & & & $\mathrm{R}$ & $F \quad F$ \\
\hline $\begin{array}{l}35 X-4,135 \\
37 X-1,0\end{array}$ & $\begin{array}{l}311.55 \\
325\end{array}$ & $\begin{array}{l}5.71 \\
5.95\end{array}$ & & & & & & & & & & \\
\hline $37 X-5,135-136$ & 332.35 & 6.05 & $F$ & M & & F & + & & & & & $\mathrm{R} R+$ \\
\hline $\begin{array}{l}38 \mathrm{X}-1,20 \\
39 \mathrm{X}-3,110\end{array}$ & $\begin{array}{l}334.5 \\
348\end{array}$ & $\begin{array}{l}6.08 \\
6.38\end{array}$ & & & & & & & & & & \\
\hline $39 \times-5,135-136$ & 351.25 & 6.45 & $\mathrm{R}$ & $\mathrm{M} / \mathrm{P}$ & + & R & F & & & & $\mathrm{R}$ & $\mathrm{R} F+$ \\
\hline $\begin{array}{l}41 X-1,120 \\
41 X-4,0\end{array}$ & $\begin{array}{l}364.3 \\
3676\end{array}$ & $\begin{array}{l}6.74 \\
6.90\end{array}$ & & & & & & & & & & \\
\hline $\begin{array}{l}41 X-4,0 \\
41 X-5,0\end{array}$ & $\begin{array}{l}367.6 \\
369.1\end{array}$ & $\begin{array}{l}0.90 \\
6.95\end{array}$ & & & & & & & & & & \\
\hline $41 X-5,120$ & 370.25 & 6.98 & & & & & & & & & & \\
\hline $41 X-5,135-136$ & 370.45 & $\begin{array}{l}6.99 \\
7.25\end{array}$ & $\mathrm{C}$ & $M$ & & $\mathrm{R}$ & F & & & R & F P & $+\mathrm{FR}$ \\
\hline $\begin{array}{l}42 X-2,0 \\
42 X-5,95\end{array}$ & $\begin{array}{l}374.2 \\
379.65\end{array}$ & $\begin{array}{l}7.25 \\
7.38\end{array}$ & & & & & & & & & & \\
\hline $42 X-6,130$ & 381.5 & 7.46 & & & & & & & & & & \\
\hline $43 X-5,135-136$ & 389.75 & 7.65 & $F$ & $\mathrm{M} / \mathrm{P}$ & & R & F & & & + & R F & $F \quad F \quad F$ \\
\hline $44 X-6,70$ & 400.2 & 7.89 & & & & & & & & & & \\
\hline $45 X-5,135-136$ & 409.05 & 8.20 & $\mathrm{R}$ & $\mathrm{M} / \mathrm{P}$ & + & $F$ & F & & - & - & $\mathrm{R}+$ & $\mathrm{F} \mathrm{F}$ \\
\hline $46 X-5,115$ & 418.45 & 8.53 & & & & & & & & & & \\
\hline $47 \mathrm{X}-5,135-136$ & $\begin{array}{l}428.25 \\
436.15\end{array}$ & $\begin{array}{l}8.71 \\
8.86\end{array}$ & $\mathrm{R}$ & M & R & C & $\mathrm{F}$ & & -1 & - & & ${ }^{R} \mathrm{~F}$ \\
\hline $\begin{array}{l}48 X-4,105 \\
48 X-5,135-136\end{array}$ & $\begin{array}{l}436.15 \\
437.95\end{array}$ & $\begin{array}{l}0.00 \\
8.94\end{array}$ & F & $\mathrm{M}$ & R & $\mathrm{R}$ & $\mathrm{F}$ & & C & + & + & $F=$ \\
\hline $49 X-1,45$ & 440.65 & 9.07 & & & & & & & & & & \\
\hline
\end{tabular}


Table 3 (continued).

\begin{tabular}{|c|c|c|c|c|c|c|c|c|c|c|c|c|}
\hline $\begin{array}{l}\text { Core, section, } \\
\text { interval }(\mathrm{cm})\end{array}$ & $\begin{array}{l}\text { Depth } \\
\text { (mbsf) }\end{array}$ & $\begin{array}{l}\text { Age } \\
(\mathrm{Ma})\end{array}$ & 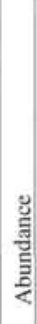 & 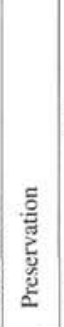 & 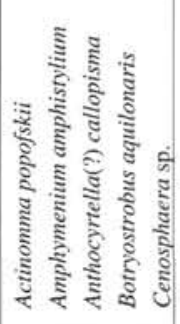 & 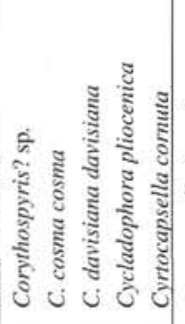 & 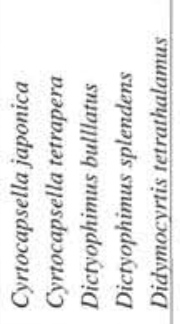 & 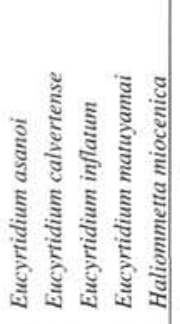 & 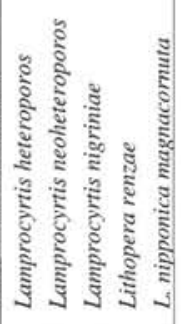 & 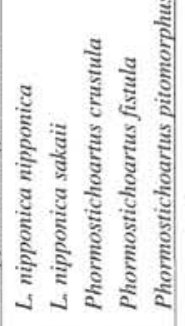 & 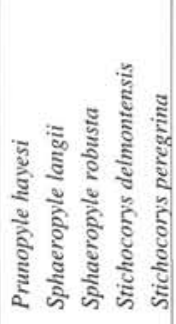 & 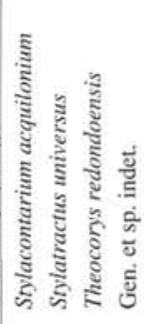 \\
\hline $49 X-4,50$ & 445.2 & 9.15 & & & & & & & & & & \\
\hline $49 X-5,135-136$ & 447.55 & 9.26 & C & $\mathrm{G} / \mathrm{M}$ & + & F & $\mathrm{R}$ & & $F$ & + & $R+$ & $\mathrm{F} R$ \\
\hline $50 \mathrm{X}-1,130$ & 451.1 & 9.43 & & & & & & & & & & \\
\hline $50 X-3,30$ & 453.1 & 9.49 & & & & & & & & & & \\
\hline $50 \mathrm{X}-3,70$ & 453.5 & 9.59 & & & & & & & & & & \\
\hline $50 X-5,135-136$ & 457.15 & 9.74 & C & $\mathrm{M} / \mathrm{P}$ & + & F & $\mathrm{R}$ & & C & $F$ & F R & $\mathrm{R} R \mathrm{R}$ \\
\hline $\begin{array}{l}50 \times-6,0 \\
50 X-7,50\end{array}$ & $\begin{array}{l}457.3 \\
458.75\end{array}$ & $\begin{array}{l}9.74 \\
9.78\end{array}$ & & & & & & & & & & \\
\hline $51 X-5,135-136$ & 466.65 & 9.97 & C & $\mathrm{M}$ & & C & $\mathrm{F}$ & & C & R & & $C+$ \\
\hline $52 X-5,135-136$ & 476.25 & 10.20 & $\mathrm{~F}$ & M & & C & $\mathrm{F}$ & & $\mathrm{C}$ & & & F $R$ \\
\hline $53 X-4,135-136$ & 484.45 & 10.40 & C & $\mathrm{M} / \mathrm{P}$ & & C & $\mathbf{R}$ & & C & $\mathrm{R}$ & $+\mathrm{C} \mathrm{C}$ & $\mathrm{F} \quad \mathrm{R} F$ \\
\hline $54 X-5,135-136$ & 495.55 & 10.66 & C & $\mathrm{M} / \mathrm{P}$ & & C & $\mathrm{F}$ & & C & $\mathrm{R}$ & + & $+\mathrm{R}$ \\
\hline $55 \mathrm{X}-3,25$ & 502.5 & 10.83 & & & & & & & & & & \\
\hline $55 X-4,135-136$ & 503.65 & 10.89 & $C$ & $\mathrm{M} / \mathrm{P}$ & + & C & $\mathrm{F}$ & & C & $\mathrm{R}$ & + & ++ \\
\hline $56 X-5,135-136$ & 514.75 & 11.52 & $\mathrm{R}$ & $\mathrm{P}$ & ++ & C & & & $\mathrm{F}$ & + & $\mathbf{P}$ & $\mathrm{R} \mathrm{F}+$ \\
\hline $57 \times-3,60$ & 520.7 & 11.85 & & & & & & & & & & \\
\hline $57 X-4,50$ & 522.1 & 12.00 & & & & & & & & & & \\
\hline $57 \times-4,140$ & 523 & 12.11 & & & & & & & & & & \\
\hline $57 X-5,137-139$ & 524.47 & 12.24 & $C$ & $\mathbf{P}$ & $t$ & $\mathrm{R}$ & P & $\mathrm{R}$ & + & $\mathrm{P}$ & P & $\mathrm{R} R \mathrm{R}$ \\
\hline $57 X-6,90$ & 525.5 & 12.33 & & & & & & & & & & \\
\hline $58 X-2,30$ & 528.5 & 12.62 & & & & & & & & & & \\
\hline $58 \mathrm{X}-3,30$ & 530 & 12.65 & & & & & & & & & & \\
\hline $58 \times-3,130$ & 531 & 12.72 & & & & & & & & & & \\
\hline $58 \mathrm{X}-4,130$ & 532.5 & $\begin{array}{l}12.76 \\
12.88\end{array}$ & C & $\mathrm{M} / \mathrm{P}$ & R & F & + & $F$ & & & & \\
\hline $\begin{array}{l}58 X-5,135-136 \\
58 X-6,80\end{array}$ & $\begin{array}{l}534.05 \\
535\end{array}$ & $\begin{array}{l}12.88 \\
12.94\end{array}$ & & & & & & & & & & F R + \\
\hline $\begin{array}{l}58 X-6,80 \\
59 X-4,140\end{array}$ & 542.3 & 13.48 & & & & & & & & & & \\
\hline $59 \times-5,135-136$ & 543.75 & 13.52 & C & M/P & $\mathrm{P}$ & F & $F C$ & P & & & P & $F+R$ \\
\hline $60 X-3,90$ & 550 & 13.67 & & & & & & & & & & \\
\hline $60 X-5,135-136$ & 553.45 & 13.82 & A & M/P & $\mathrm{R}$ & F & + & $\mathrm{R}$ & & & $\mathrm{R}$ & F F R \\
\hline $61 X-3,40$ & 559 & 14.06 & & & & & & & & & & \\
\hline $61 X-5,135-136$ & 562.95 & 14.44 & A & $\mathrm{M} / \mathrm{P}$ & + & C $\stackrel{\mathrm{R}}{\mathrm{F}}$ & & & P & & & \\
\hline $62 X-5,135-136$ & 572.65 & 15.35 & A & M & & C F & $\mathrm{R} F$ & $\mathrm{R}$ & & & $\mathbf{P}$ & $+\mathrm{C}+$ \\
\hline $63 \times-4,70$ & 580 & 16.04 & & & & & & & & & & \\
\hline $63 X-5,135-136$ & $\begin{array}{l}582.15 \\
590.25\end{array}$ & $\begin{array}{l}16.24 \\
16.96\end{array}$ & $\begin{array}{l}\mathrm{A} \\
\mathrm{F}\end{array}$ & $\begin{array}{c}\mathrm{M} \\
\mathrm{M} / \mathrm{P}\end{array}$ & $+\mathrm{P}$ & $\mathrm{F} \underset{\mathrm{F}}{\mathrm{C}}$ & $\begin{array}{ll}+ & \mathrm{C} \\
\mathrm{R} & \mathrm{C}\end{array}$ & & & & +- & $\begin{array}{l}\mathrm{R}++ \\
\mathrm{F}+\end{array}$ \\
\hline $\begin{array}{l}64 X-4,135-136 \\
65 X-1,10\end{array}$ & $\begin{array}{l}590.25 \\
594.2\end{array}$ & $\begin{array}{l}16.96 \\
17.31\end{array}$ & & & & & & & & & & \\
\hline $65 \times-4,40$ & 599 & 17.65 & & & & & & & & & & \\
\hline $65 X-5,135-136$ & 601.45 & 18.09 & $\mathrm{~F}$ & P & C & ? & $? \mathrm{R}$ & & & & & C \\
\hline $65 X-6,120$ & 602.8 & 18.32 & & & & & & & & & & \\
\hline $66 \mathrm{X}-5,134-135$ & 611.14 & 19.78 & $\mathrm{R}$ & P & ++ & & & & & & & $\mathrm{R}$ \\
\hline $67 X-5,135-136$ & 620.65 & 21.48 & $\mathrm{R}$ & $\mathrm{P}$ & $\mathrm{R}$ & & & & & & & \\
\hline $68 X-5,135-136$ & 630.15 & 23.15 & R & $\mathrm{P}$ & C & & & & & & + & \\
\hline $69 X-5,135-136$ & 639.75 & 24.84 & B & & & & & & & & & \\
\hline
\end{tabular}

Note: See note to Table 2.

spond well with the uppermost three zones (Botryostrobus aquilonaris Zone [0.0-0.45 Ma], Stylatractus universus Zone [0.45-0.88 Ma], Eucyrtidium matuyamai Zone [0.88-1.98 Ma]) defined in Foreman's (1975) zonal scheme. Although the species that defined zones for North Pacific sediments older than 2 Ma are present in sediments analyzed in this study, either they do not always occur in high enough abundances or their ranges do not always match those given for specific zonations.

\section{RADIOLARIAN SITE SUMMARIES Site 881 (Holes 881C and 881D)}

At Site 881, the westernmost site occupied by Leg 145 (Table 1), radiolarian-bearing sediments range in age from middle late Miocene to Holocene. For this study, analysis of the radiolarian assemblage was confined to no more than two samples per core from Holes $881 \mathrm{C}$ and $881 \mathrm{D}$. The results from Hole 881D were combined with those from Hole $881 \mathrm{C}$ so as to provide a complete composite section. All the major paleomagnetic events within the last $4 \mathrm{~m} . \mathrm{y}$. are recorded in sediments from this site. This composite section contains no identifiable hiatuses and apparently represents a continuous high-sedimentation-rate $(\sim 42 \mathrm{~m} / \mathrm{m} . \mathrm{y}$.) record of variations in radiolarian assemblages for this region of the North Pacific extending well into the late Miocene.

Radiolarian preservation (Table 2) is good to moderate throughout the upper $150 \mathrm{~m}(\sim 2.4 \mathrm{~m} . \mathrm{y}$.). In the 150 - to 300 -m portion of the record from this site, radiolarians are masked by the presence of high concentrations of diatoms and preservation was only moderate to poor. Concentrations of radiolarians (Table 2; Fig. 2) reach their highest levels ( $>25,000$ radiolarians/gram) in samples of middle late Miocene age at the base of Hole 881C.

Range data for the thirty-nine radiolarian species at Site 881 are shown in Table 2. Ages of each sample analyzed were calculated using the magnetostratigraphy, with ages for magnetic events taken from Cande and Kent (1992). The estimated age of 7.55 Ma for the shift in dominance from Stichocorys delmontensis to Stichocorys peregrina (calculated from siliceous faunal data in Sites 885,886 , 
Table 4. Census counts for stratigraphically important species in Hole 885A.

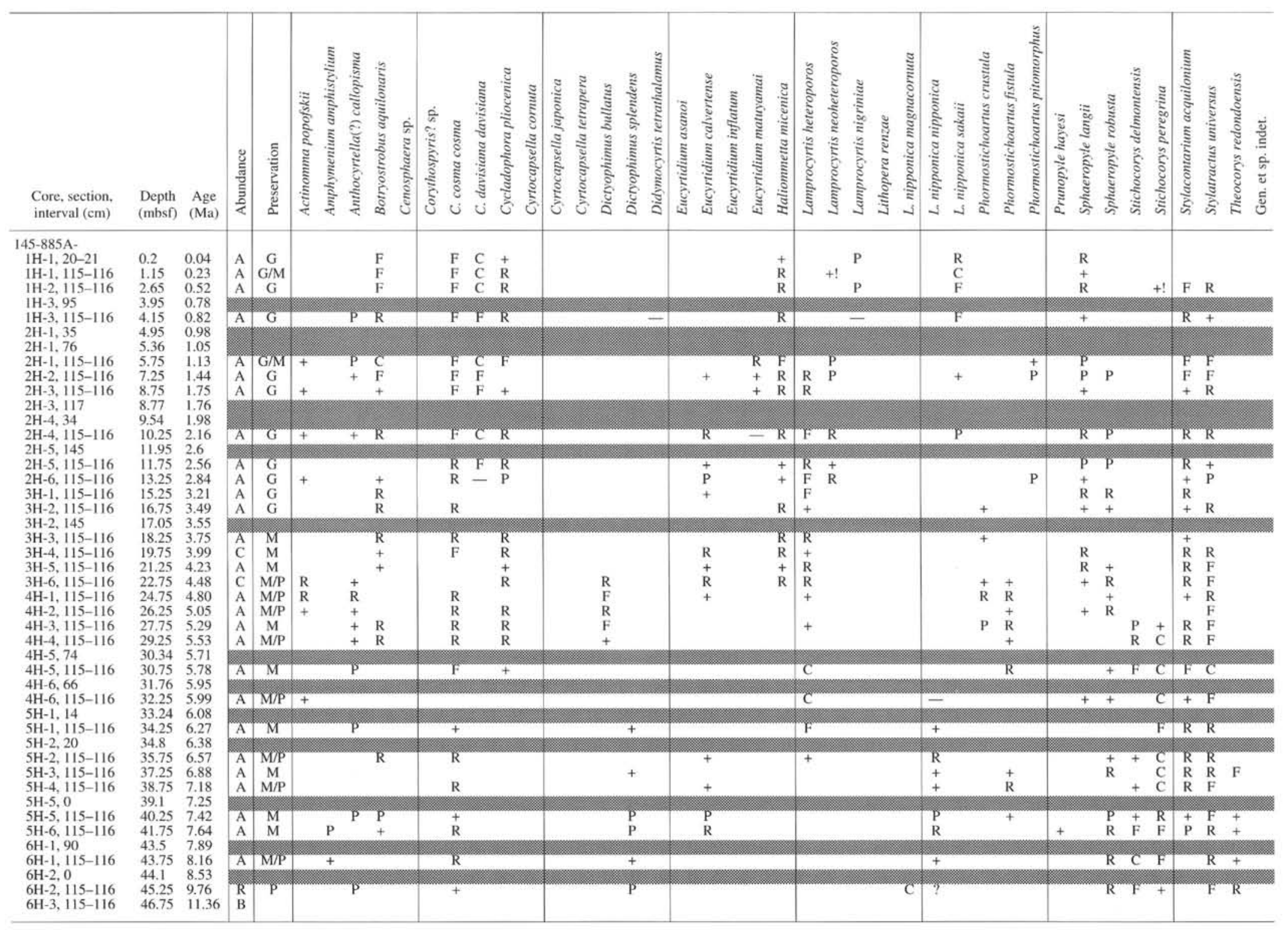

Note: See note to Table 2. 
Table 5. Census counts for stratigraphically important species in Hole 886C.

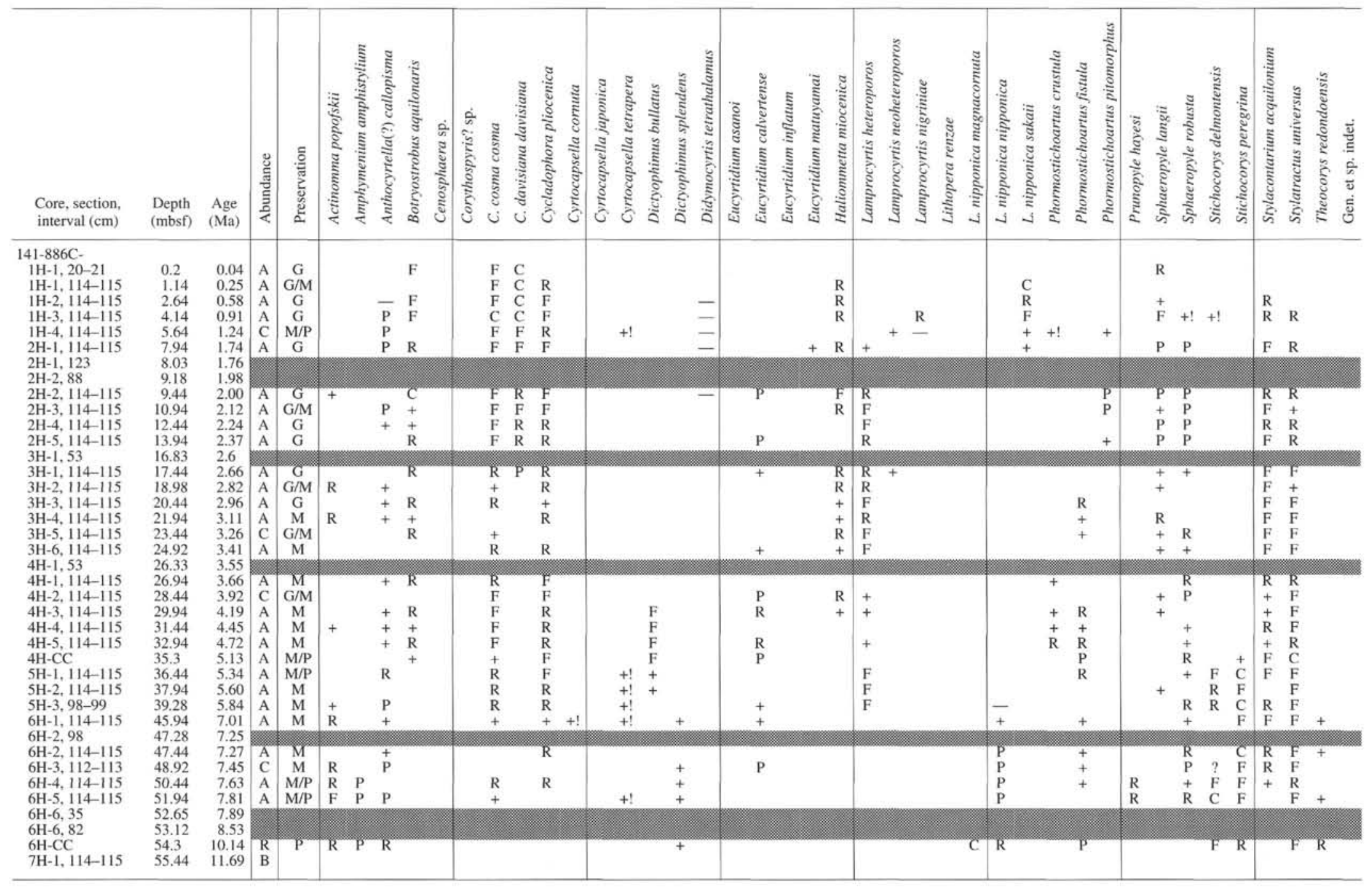

Note: See note to Table 2 . 


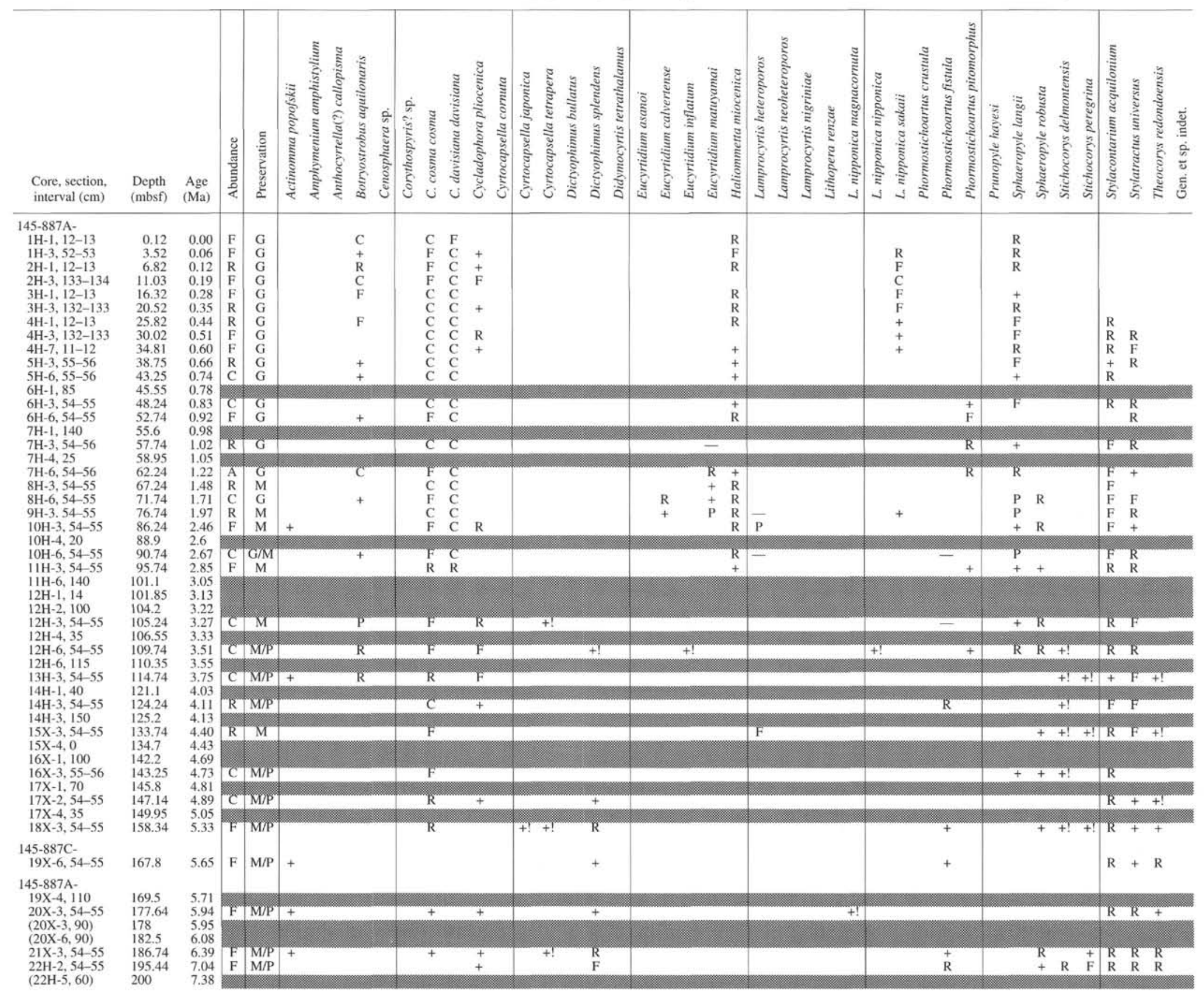




\section{Table 6 (continued).}

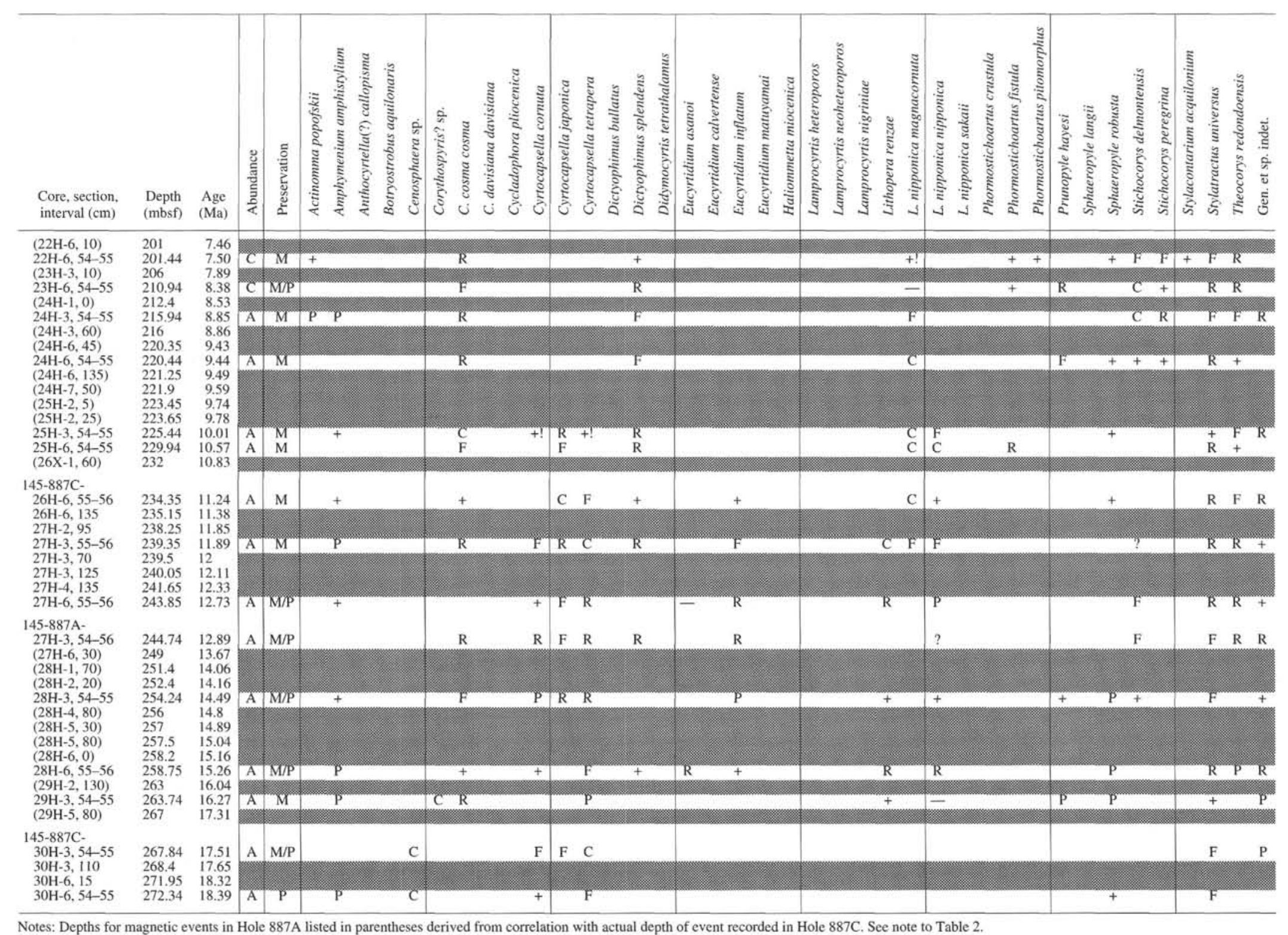


Figure 2. Number of radiolarians per gram of dry weight of sediment at each Leg 145 site examined in this study vs. age (Ma) using Cande and Kent (1992) time scale. Absolute values of radiolarian concentrations were made only for randomly settled samples used in radiolarian survey.

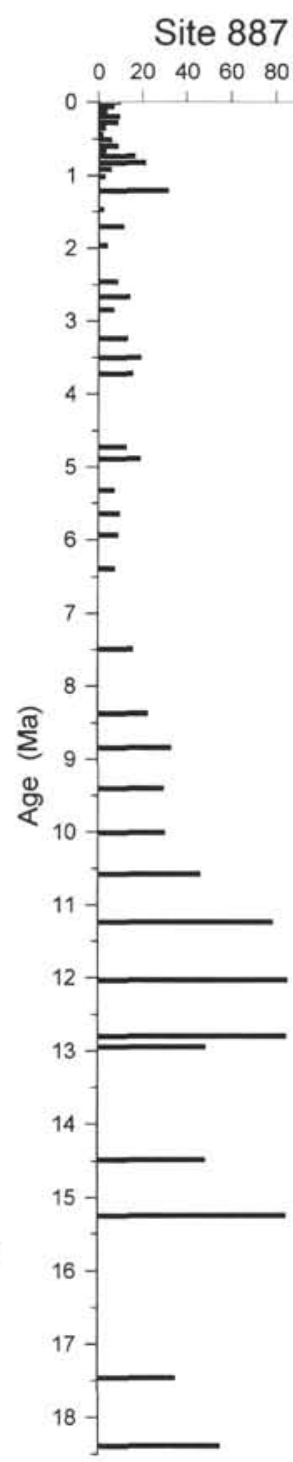

Site 885

Site 884

Site 881

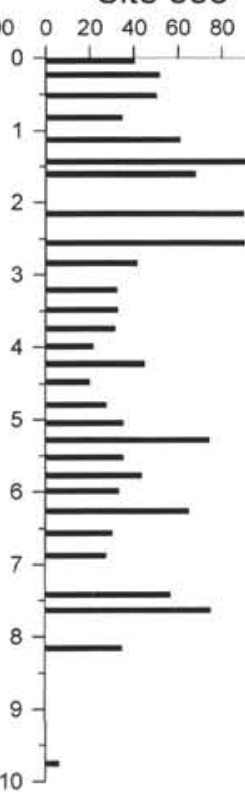

$00 \quad 0 \quad 10 \quad 20 \quad 30 \quad 40 \quad 50$

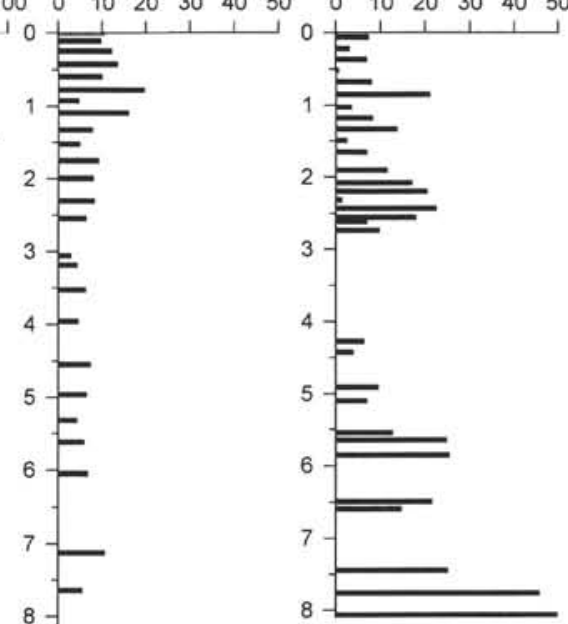

Site 886

$\begin{array}{llllll}0 & 10 & 20 & 30 & 40 & 50\end{array}$

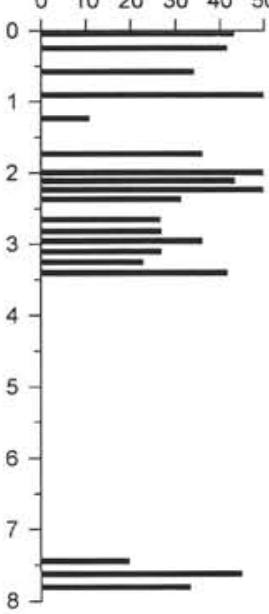

and 887) served as an additional control point for calculating ages of Site 881 samples because the oldest identifiable magnetic event was so great a distance $(>125 \mathrm{~m})$ from the bottom of Hole 881C.

The first three cores from Hole $881 \mathrm{C}$ contain a radiolarian assemblage characteristic of that described for the North Pacific Botryostrobus aquilonaris Zone, with the dominance of Cycladophora cosma cosma, Cycladophora davisiana davisiana, and Sphaeropyle langii, and the LO of Lychnocanoma nipponica sakaii (Sample 145$881 \mathrm{C}-1 \mathrm{H}-\mathrm{CC}$ ) (Table 2). The addition of Stylacontarium acquilonium and Stylatractus universus in sediments from Cores 145-881C$4 \mathrm{H}$ through $-6 \mathrm{H}$ indicates that this assemblage is similar to that reported for the Stylatractus universus Zone. The morphological evolution from Lamprocyrtis neoheteroporos to Lamprocyrtis nigriniae occurs at the base of this interval. The presence of Eucyrtidium matuyamai in Samples 145-881C-7H-CC through -13H-CC and the accompanying radiolarian assemblage conform to that representative of the Eucyrtidium matuyamai Zone. The termination of the Jaramillo Subchron recorded in Core $145-881 \mathrm{C}-7 \mathrm{H}$ and the identification of the Olduvai Subchron in Cores $145-881 \mathrm{C}-12 \mathrm{H}$ and $-13 \mathrm{H}$ confirms that this sequence correlates with that defined for the $E$. matuyamai Zone. The LO of both L. heteroporos (Sample 145-881C-13H-CC) and Sphaeropyle robusta (Sample 145-881C-11H-CC) are recorded at or near the base of this interval.

Because the apparent LO of Stichocorys peregrina is much older in Leg 145 sites than in North Pacific sites south of $40^{\circ} \mathrm{N}(\sim 5-6 \mathrm{Ma}$ vs. $\sim 3 \mathrm{Ma}$ ), it is impossible to place radiolarian sequences properly below Core 145-881C-13H in any of the proposed North Pacific radiolarian zonations. The FO of $L$. heteroporos also appears to take place earlier ( 6.6 Ma) in sediments from Leg 145 sites compared to mid- and low-latitude Pacific sites, where its FO has been estimated at $\sim 4.4 \mathrm{Ma}$ and $\sim 3.3 \mathrm{Ma}$, respectively.

Species that experience relatively sharp FOs or LOs in the sediment sequence in Holes $881 \mathrm{C}$ and $881 \mathrm{D}$ below $2 \mathrm{Ma}(\sim 110 \mathrm{mbsf})$ are C. davisiana davisiana (FO between Samples 145-881D-2H-CC and $-3 \mathrm{H}-\mathrm{CC}$ ), S. peregrina (LO 145-881C-27X-1, 20-21 cm, and -25X-4, $50-51 \mathrm{~cm}$ ), Stichocorys delmontensis (LO between Samples 145881C-27X-5, 20-21 cm, and -27X-1, 20-21 cm), Dictyophimus splendens (LO between Samples 145-881C-29X-3, 20-21 cm, and $30 \mathrm{X}-1,21-22 \mathrm{~cm}$ ), L. heteroporos (FO between Samples 145-881C$30 \mathrm{X}-7,22-23 \mathrm{~cm}$, and $-32 \mathrm{X}-1,20-21 \mathrm{~cm})$, Lychnocanoma nipponica nipponica (LO between Samples 145-881C-32X-1, 20-21 cm, and $30 \mathrm{X}-7,22-23 \mathrm{~cm}$ ), and $S$. acquilonium (FO between Samples 145$881 \mathrm{C}-35 \mathrm{X}-1,22-23 \mathrm{~cm}$, and $-36 \mathrm{X}-1,29-30 \mathrm{~cm}$ ) (Table 2). The switch in dominance from $S$. delmontensis to $S$. peregrina occurs at Sample 145-881C-35X-1, 22-23 cm (Table 2).

\section{Site 884 (Hole 884B)}

Site 884 , the northernmost site drilled on Leg 145 in the western North Pacific (Table 1), was the deepest hole drilled as part of a depth 
transect down the flank of the Detroit Seamount. A thick sediment sequence at the base of this seamount known as the Meiji Tongue (Drift) was sampled at this site. Radiolarians are present throughout the upper $630 \mathrm{~m}$ of Hole $884 \mathrm{~B}$. Biogenic silica is absent in much of the interval of the core below this depth; and the few radiolarians present in samples below $630 \mathrm{mbsf}$ are poorly preserved. The radiolarians above $630 \mathrm{mbsf}$ at Site 884 range in age from early Miocene to Holocene. Although an excellent magnetic reversal record was recovered from sediments in Hole $884 \mathrm{~B}$, several small hiatuses $(<1$ m.y.) below $435 \mathrm{mbsf}$ in the core make it somewhat difficult to assign the proper event to the recorded reversal. For the upper $535 \mathrm{mbsf}$, the paleomagnetic event stratigraphy as outlined in "Interpretation 2" of the Shipboard Scientific Party (1993a) was followed. However, below this interval we chose the paleomagnetic events based on diatom stratigraphy (Barron and Gladenkov, this volume). This latter interpretation places the normal polarity interval between 535 and 542.3 mbsf within Subchrons C5AA and C5AB; positions the normal event $\mathrm{C} 5 \mathrm{AC}$ between 550 and $559 \mathrm{mbsf}$; and identifies the terminations of Chrons C5C, C5D, and C5E at 580, 594.2, and 602.8 mbsf, respectively. The oldest three paleomagnetic events were recorded during shipboard measurement of inclination with a cryogenic magnetometer although not listed in Shipboard Scientific Party (1993a) tables. The average sedimentation rate throughout the radiolarian-bearing sequence from the early Miocene to Holocene is quite high $(\sim 33 \mathrm{~m} /$ m.y.). In most instances, the radiolarian assemblage in one sample from every core was examined except in the uppermost Miocene through lower Pliocene sequences where only one sample from every two cores was studied.

Radiolarian preservation is good only through the upper 2-m.y. record from Site 884 (Table 3). From 2 to $18 \mathrm{Ma}$, most samples contain moderate to poorly preserved radiolarians. As was the case with Site 881, high concentrations of large diatoms mask radiolarians from the early Pliocene throughout much of the late Miocene (3.55$9 \mathrm{Ma})$. Radiolarians, when present in samples below $595 \mathrm{mbsf}$, are poorly preserved. Concentrations of radiolarians are lower compared with those from the three southern sites occupied on Leg 145, with the only samples containing abundant ( $>25,000$ radiolarians/gram) radiolarians found in the lower middle Miocene ( 14-16 Ma) (Table 3; Fig. 2).

The ranges of the 39 species are presented in Table 3 . An age was calculated for each sample examined using the magnetostratigraphy and the magnetic time scale of Cande and Kent (1992).

The radiolarian assemblage in the uppermost $14 \mathrm{~m}$ (through Sample $145-884 \mathrm{~B}-2 \mathrm{H}-5,135-136 \mathrm{~cm}$ ) in Hole $884 \mathrm{~B}$ is characteristic of the Botrystrobus aquilonaris Zone, with the presence of Cycladophora davisiana davisiana, Cycladophora cosma cosma, Lychnocanoma nipponica sakaii, and Sphaeropyle langii (Table 3). Stylacontarium acquilonium and Stylatractus universus in Cores 145-884B-3H through $-6 \mathrm{H}$ indicate that this sequence most likely is representative of the Stylatractus universus Zone. The radiolarian Eucyrtidium matuyamai is confined to the lower half of Core $145-884 \mathrm{~B}-7 \mathrm{H}$ through Core 145-884B-12H, which places this sequence within the Eucyrtidium matuyamai Zone (North Pacific radiolarian zonation of Foreman, 1975). The range of the E. matuyamai Zone at this site is bracketed by the Jaramillo and Olduvai Subchrons. Although they are not identified in every sample, the LOs of Sphaeropyle robusta and Lamprocyrtis heteroporos occur within this interval (between Core 145-884B-11H and Sample 145-884B-12X-1, 68-69 cm).

Below this level in Hole $884 \mathrm{~B}$, it is not possible to place the radiolarian sequence within any of the existing North Pacific radiolarian zonations because of the apparently older LO of Stichocorys peregri$n a(\sim 5.6 \mathrm{Ma}$ vs. $\sim 3 \mathrm{Ma})$ and the very rare occurrences of Lamprocyrtis heteroporos at this site. Species with clearly delineated FOs and LOs that could be of stratigraphic importance below $2 \mathrm{Ma}$ are $C$. davisiana davisiana (FO between Samples 145-884B-17X-5, 135$136 \mathrm{~cm}$, and $-18 \mathrm{X}-5,135-136 \mathrm{~cm}$ ), Dictyophimus splendens (LO be- tween Samples 145-884B-29X-1, 135-136 cm, and -31X-5, 135-136 $\mathrm{cm}$; FO between Samples 145-884B-61X-5, 135-136 cm, and -62X$5,135-136 \mathrm{~cm}$ ), S. acquilonium (FO between Samples 145-884B$43 \mathrm{X}-5,135-136 \mathrm{~cm}$, and $-45 \mathrm{X}-5,135-136 \mathrm{~cm})$, Lychnocanoma nipponica magnacornuta (LO between Samples 145-884B-47X-5, 135$136 \mathrm{~cm}$, and $-48 \mathrm{X}-5,135-136 \mathrm{~cm}$; FO between Samples 145-884B$57 \mathrm{X}-5,137-139 \mathrm{~cm}$, and $-58 \mathrm{X}-5,135-136 \mathrm{~cm})$, Cyrtocapsella japonica (LO between Samples 145-884B-51X-5, 135-136 cm, and $-52 X-5,135-136 \mathrm{~cm}$ ), Cyrtocapsella cornuta (LO between Samples 145-884B-56X-5, 135-136 cm, and -57X-5, 137-139 cm), Cyrtocapsella tetrapera (LO between Samples 145-884B-56X-5, 135-136 $\mathrm{cm}$, and $-57 \mathrm{X}-5,137-139 \mathrm{~cm}$ ), Eucyrtidium inflatum (LO between Samples 145-884B-56X-5, 135-136 cm, and -57X-5, 137-139 cm; FO between Samples 145-884B-61X-5, 135-136 cm, and -62X-5, $135-136 \mathrm{~cm}$ ), Lithopera renzae (LO between Samples 145-884B$56 \mathrm{X}-5,135-136 \mathrm{~cm}$, and $-57 \mathrm{X}-5,137-139 \mathrm{~cm})$, Eucyrtidium asanoi (LO between Samples 145-884B-59X-5, 135-136 cm, and -60X-5, 135-136 cm; FO between Samples 145-884B-62X-5, 135-136 cm, and $-63 \mathrm{X}-5,135-136 \mathrm{~cm}$ ), Corythospyris? sp. (LO between Samples $145-884 \mathrm{~B}-61 \mathrm{X}-5,135-136 \mathrm{~cm}$, and $-62 X-5,135-136 \mathrm{~cm}$; FO between Samples 145-884B-63X-5, 135-136 cm, and -64X-4, 135-36 $\mathrm{cm}$ ), and C. cosma cosma (FO between Samples 145-884B-64X-4, $135-136 \mathrm{~cm}$, and $-65 \mathrm{X}-5,135-136 \mathrm{~cm}$ ) (Table 3).

\section{Site 885 (Hole 885A)}

Site 885, one of two of the southernmost sites drilled on Leg 145, is located in the central North Pacific. The upper $45.5 \mathrm{~m}$ of sediment contain radiolarians of late Miocene to Holocene in age. Radiolarians were examined in samples taken at approximately $1.5-\mathrm{m}$ intervals (one sample/section) from Hole $885 \mathrm{~A}$. Although not all present, enough of the magnetic events were identified in Hole 885A material to provide good chronostratigraphic control. In the radiolarian-bearing sequence, the sedimentation rate averages about $5 \mathrm{~m} / \mathrm{m} . \mathrm{y}$. based on the magnetostratigraphy and biostratigraphy.

Well-preserved radiolarians occur in the upper $17 \mathrm{~m}(\sim 3.55 \mathrm{m.y}$. of this hole (Table 4). Radiolarian preservation is either moderate or moderate to poor in the remaining samples in which radiolarians were present, except for the slide containing the oldest siliceous fauna where radiolarians were poorly preserved. A tremendous influx of diatoms during the late Miocene to early Pliocene makes it difficult to examine radiolarians throughout the time interval between $\sim 3.7-7.2$ Ma (Sample 145-885A-3H-3, 115-116 cm, through -5H-4, 115-116 $\mathrm{cm})$. Overall concentrations of radiolarians are high when compared to those at other Leg 145 sites, with highest values $(>65,000$ radiolarians/gram) occurring in samples of late Pliocene to early Pleistocene age (Table 4; Fig. 2).

Table 4 shows the ranges of the 39 species examined in sediments from Site 885 . The calculated age for each sample is based on the magnetostratigraphy, with ages of specific magnetic events taken from Cande and Kent (1992).

The radiolarian assemblage in the upper $1.15 \mathrm{~m}$ corresponds to that described for the North Pacific Botryostrobus aquilonaris Zone, with the presence of Botryostrobus aquilonaris, Cycladophora davisiana davisiana, Cycladophora cosma cosma and Sphaeropyle langii (Table 4). Samples from Sections $145-885 \mathrm{~A}-1 \mathrm{H}-2$ and $-1 \mathrm{H}-3$ contain radiolarians similar to those representative of the Stylatractus universus Zone, with the addition of Stylacontarium acquilonium and Stylatractus universus. The presence of Eucyrtidium matuyamai in Sections $145-885 \mathrm{~A}-2 \mathrm{H}-1$ through $-2 \mathrm{H}-3$ and the identification of the Jaramillo and Olduvai subchrons bracketing this sequence indicate that this interval corresponds to that of the Eucyrtidium matuyamai Zone. Both Lamprocyrtis heteroporos and Sphaeropyle robusta become extinct approximately midway through this unit.

As with other Leg 145 sites, the older LO of Stichocorys peregri$n a$ ( $\sim 5 \mathrm{Ma}$ vs. $\sim 3 \mathrm{Ma})$ and FO of $L$. heteroporos ( 6.6 Ma vs. $\sim 3.3-$ 
4.4 Ma) preclude proper placement of this sequence within previously constructed North Pacific radiolarian zonal schemes. Specific events of stratigraphic potential below $2 \mathrm{Ma}$ in Hole $885 \mathrm{~A}$ are the FO of $C$. davisiana davisiana (between Samples 145-885A-2H-5, 115$116 \mathrm{~cm}$, and $-2 \mathrm{H}-6,115-116 \mathrm{~cm})$, the LOs of S. peregrina and Stichocorys delmontensis (between Samples 145-885A-4H-2, 115-116 $\mathrm{cm}$, and $-4 \mathrm{H}-3,115-116 \mathrm{~cm}$ ), the FO of $L$. heteroporos (between Samples $145-885 \mathrm{~A}-5 \mathrm{H}-2,115-116 \mathrm{~cm}$, and $-5 \mathrm{H}-3,115-116 \mathrm{~cm})$, the $S$. delmontensis to $S$. peregrina change in dominance (Sample 145$885 \mathrm{~A}-5 \mathrm{H}-5,115-116 \mathrm{~cm}$ ), the FO of $S$. acquilonium (between Samples $145-885 \mathrm{~A}-5 \mathrm{H}-6,115-116 \mathrm{~cm}$, and $-6 \mathrm{H}-1,115-116 \mathrm{~cm}$ ) and the LO of Lychnocanoma nipponica magnacornuta (between Samples $145-885 \mathrm{~A}-6 \mathrm{H}-1,115-116 \mathrm{~cm}$, and $-6 \mathrm{H}-2,115-116 \mathrm{~cm}$ ) (Table 4).

\section{Site 886 (Hole 886C)}

Site 886 , like Site 885 , is located in the central portion of the North Pacific. Because of its proximity to Site 885 (within $\sim 2.2 \mathrm{~km}$ ), these sites contain somewhat similar records, except that Core 145$886 \mathrm{C}-5 \mathrm{H}$ failed to recover any sediment in the lower half $(4.5-9.5 \mathrm{~m})$ of the core barrel. Radiolarians are absent in Hole $886 \mathrm{C}$ below 54.5 $\mathrm{m}$. The age of the radiolarian-bearing sequence is late Miocene to Holocene. Radiolarians were examined in samples at approximately 1.5$\mathrm{m}$ intervals (one sample/section). The magnetostratigraphy does not have the resolution of that for Site 885 , with fewer identifiable magnetic events. The average sedimentation rate, based on both biostratigraphy and magnetostratigraphy for the upper $54 \mathrm{~m}$ of Hole $886 \mathrm{C}$, is $6.2 \mathrm{~m} / \mathrm{m} . \mathrm{y}$.

Except for Sample 145-886C-1H-4, 114-115 cm, preservation of the siliceous fauna in Hole $886 \mathrm{C}$ varies between good and moderate throughout the last 4.75 m.y. ( upper $33 \mathrm{~m}$ ) (Table 5). Below this level, silica dissolution increases with radiolarian preservation only moderate to poor until sediment from Hole $886 \mathrm{C}$ becomes barren of radiolarians in the top of Core $145-886 \mathrm{C}-7 \mathrm{H}$. As at Site 885 , radiolarians are masked by high numbers of diatoms, which flood the upper Miocene through early Pliocene samples ( 3.55-7.3 Ma). Radiolarian concentrations are high, although not quite as high as at Site 885 , with maximum values ( $>35,000$ radiolarians/gram) occurring in upper Pliocene through lower Pleistocene samples (Table 5; Fig. 2).

Ranges of the 39 species in sediments from Site 886 are shown in Table 5. The estimated age of each sample examined is based on the ages of the paleomagnetic events identified in the core using the magnetic time scale of Cande and Kent (1992).

Sediment from the upper $1.14 \mathrm{~m}$ contains a radiolarian fauna representative of the North Pacific Botryostrobus aquilonaris Zone, including Cycladophora davisiana davisiana, Cycladophora cosma cosma, Sphaeropyle langii and the LO of Lychnocanoma nipponica sakaii (Sample 145-886C-1H-1, 114-115 cm) (Table 5). The next two sections $(145-886 \mathrm{C}-1 \mathrm{H}-2$ and $-1 \mathrm{H}-3)$ contain siliceous fauna typical of the Stylatractus universus Zone, with the addition of Stylacontarium acquilonium and Stylatractus universus. A small hiatus may exist in Hole $886 \mathrm{C}$ within the interval from the top of Section $145-886 \mathrm{C}-1 \mathrm{H}-4$ to the top of Section $145-886 \mathrm{C}-2 \mathrm{H}-1$, based on the presence of Eucyrtidium matuyamai in only one sample and the inability to identify the Brunhes/Matuyama magnetic boundary as well as the onset and termination of the Jaramillo Subchron in records from this hole. The LOs of Sphaeropyle robusta and Lamprocyrtis heteroporos occur in Sample 145-886C-2H-1, 114-115 cm, above the termination of the Olduvai Subchron.

Species at Site 886 that exhibit distinct FOs and/or LOs that have stratigraphic potential below $2 \mathrm{Ma}$ are $C$. davisiana davisiana (FO between Samples 145-886C-3H-1, 114-115 cm, and -3H-2, 114-115 $\mathrm{cm}$ ), Stichocorys peregrina (LO between Samples $145-886 \mathrm{C}-4 \mathrm{H}-5$, $114-115 \mathrm{~cm}$, and $-4 \mathrm{H}-\mathrm{CC}$ ), Stichocorys delmontensis (LO between Samples 145-886C-4H-CC, and -5H-1, 114-115 cm), S. acquilonium (FO between Samples 145-886C-6H-4, 114-115 cm, and $-6 \mathrm{H}-5$,
114-115 cm), and Lychnocanoma nipponica magnacornuta (LO between Samples 145-886C-6H-5, 114-115 cm, and -6H-CC) (Table 5 ). The change in dominance from $S$. delmontensis to $S$. peregrina occurs at Sample 145-886C-6H-3, 114-115 cm (Table 5).

\section{Site 887 (Holes 887A and 887C)}

Gulf of Alaska Site 887, the northernmost site occupied during Leg 145, contains radiolarian-bearing sediment of early Miocene age through Holocene. Analysis of radiolarians for this study was restricted to a maximum of two samples per core from Hole 887A supplemented with samples from Hole $887 \mathrm{C}$ to complete several unrecovered portions of the sediment sequence in Hole $887 \mathrm{~A}$. The magnetic reversal record at this site is excellent, with all but a few reversals clearly identifiable. The magnetostratigraphy derived from this record (Shipboard Scientific Party, 1993b) agrees with the diatom biostratigraphy (Barron and Gladenkov, this volume). The sedimentation rate in this nearly continuous sequence averages $\sim 15 \mathrm{~m} /$ m.y., with much higher rates $(\sim 40 \mathrm{~m} / \mathrm{m}$.y.) since the onset of the Pleistocene and lower rates $(\sim 7 \mathrm{~m} / \mathrm{m} . \mathrm{y}$.) for the middle and early Miocene. Of the five Leg 145 sites surveyed in this study, evidence of reworking was most obvious at Site 887 , especially from the bottom of Cores $145-887 \mathrm{~A}-12 \mathrm{H}$ and $145-887 \mathrm{C}-12 \mathrm{H}$ through Cores $145-$ $887 \mathrm{~A}-22 \mathrm{H}$ and $145-887 \mathrm{C}-22 \mathrm{H}$ (approximately $110-200 \mathrm{mbsf}$ ).

In most samples from the uppermost $90 \mathrm{~m}$ (last $\sim 2.6 \mathrm{~m} . \mathrm{y}$.), radiolarian preservation is good (Table 6). Preservation of the siliceous fauna decreases throughout the remainder of the sedimentary record, varying between moderate and poor. As was the case at the other four Leg 145 sites examined in this study, radiolarians were diluted in sediments from Site 887 by large quantities of diatoms from the late $\mathrm{Mi}$ ocene through the early Pliocene ( $3.55-7.5 \mathrm{Ma})$. Concentrations of radiolarians are slightly higher than those calculated for the other high-latitude North Pacific Site (884), with highest concentrations (>25,000 radiolarians/gram) confined to samples between $215 \mathrm{mbsf}$ and the bottom of the core ( $\sim-18 \mathrm{Ma}$ ) (Table 6; Fig. 2).

Table 6 lists the ranges of the 39 species in sediments from Site 887. Ages of each sample were calculated using the magnetostratigraphy, applying the geochronologic time scale of Cande and Kent (1992).

The first three cores from Hole $887 \mathrm{~A}$ contain a radiolarian assemblage similar to that described for the North Pacific Botryostrobus aquilonaris Zone with the presence of B. aquilonaris, Cycladophora davisiana davisiana, Cycladophora cosma cosma, Sphaeropyle langii, and the LO of Lychnocanoma nipponica sakaii (Sample 145$887 \mathrm{~A}-1 \mathrm{H}-3,52-53 \mathrm{~cm}$ ) (Table 6). The additional presence of Stylacontarium acquilonium and Stylatractus universus in sediments from Cores $145-887 \mathrm{~A}-4 \mathrm{H}$ through $-7 \mathrm{H}$ indicates that this sequence is most likely representative of the Stylatractus universus Zone. The range of Eucyrtidium matuyamai, which defines the North Pacific Zone of the same name, extends from the base of Core 145-887A-7H through Core $145-887 \mathrm{~A}-9 \mathrm{H}$. As with the other Leg 145 sites, the LO of Sphaeropyle robusta (Sample 145-887A-8H-6, 54-55 cm) is recorded in sediments within this interval. None of the proposed North Pacific radiolarian zonations could be applied to the radiolarian assemblage in the composite section from Site 887 below Core 145 887A-9H ( 2 Ma).

Several species exhibit distinct ranges with abrupt FOs and LOs in the sediment record from Site 887 below the FO of E. matuyamai and are potentially useful as stratigraphic markers. These include $C$. davisiana davisiana (FO between Samples 145-887A-11H-3, 54-55 $\mathrm{cm}$, and $-12 \mathrm{H}-3,54-55 \mathrm{~cm}$ ), Dictyophimus splendens (LO between Samples 145-887A-16X-3, 55-56 cm, and -17X-2, 54-55 cm), S. acquilonium (FO between Samples 145-887A-22H-6, 54-55 cm, and $23 \mathrm{H}-6,54-55 \mathrm{~cm}$ ), Lychnocanoma nipponica magnacornuta (LO between Samples 145-887A-23H-6, 54-55 cm, and -24H-3, 54-55 cm; FO between Samples 145-887C-27H-3, 55-56 cm, and -27H-6, 55- 
$56 \mathrm{~cm}$ ), Cyrtocapsella japonica (LO between Samples 145-887A$24 \mathrm{H}-6,54-55 \mathrm{~cm}$, and $-25 \mathrm{H}-3,54-55 \mathrm{~cm})$, Cyrtocapsella tetrapera (LO between Samples 145-887A-25H-6, 54-55 cm, and 145-887C$26 \mathrm{H}-6,55-56 \mathrm{~cm}$ ), Eucyrtidium inflatum (LO between Samples 145$887 \mathrm{~A}-25 \mathrm{H}-6,54-55 \mathrm{~cm}$, and $145-887 \mathrm{C}-26 \mathrm{H}-6,55-56 \mathrm{~cm}$; FO between Samples 145-887A-28H-6, 55-56 cm, and -29H-3, 54-55 cm), Cyrtocapsella cornuta (LO between Samples 145-887C-26H-6, 55$56 \mathrm{~cm}$, and $-27 \mathrm{H}-3,55-56 \mathrm{~cm}$ ), Lithopera renzae (LO between Samples $145-887 \mathrm{C}-26 \mathrm{H}-6,55-56 \mathrm{~cm}$, and $-27 \mathrm{H}-3,55-56 \mathrm{~cm}$; FO between Samples 145-887A-29H-3, 54-55 cm, and 145-887C-30H-3, $54-55 \mathrm{~cm}$ ), and C. cosma cosma (FO between Samples 145-887A$29 \mathrm{H}-3,54-55 \mathrm{~cm}$, and $145-887 \mathrm{C}-30 \mathrm{H}-3,54-55 \mathrm{~cm}$ ) (Table 6). The switch in dominance from Stichocorys delmontensis to Stichocorys peregrina is recorded in sediments from Sample 145-887A-22H-6, $54-55 \mathrm{~cm}$ (Table 6).

\section{STRATIGRAPHIC AND GEOGRAPHIC RADIOLARIAN RANGES}

A chart listing the FOs and LOs of most of the species surveyed in this study is presented in Table 7. Recording "events" of this type is a more basic, first-order method of building a radiolarian biostratigraphy than generating a zonal scheme. We have followed the lead of several other studies of this type (Riedel and Sanfilippo, 1971; Kling; 1973; Foreman, 1975; Reynolds, 1980; Sakai; 1980; Nigrini, 1985) in using this method to summarize the sequence of Miocene to Pleistocene events recorded in North Pacific sediments from each of our Leg 145 Sites. It is a particularly appropriate and prudent approach when one is dealing with unique material from sites that are geographically distant from each other. As more material, particularly Miocene, is recovered from the North Pacific, our events list will be refined and, in time, it will become evident which events are consistently present, isochronous, and easily recognized. It is only then that a satisfactory zonal scheme, applicable over a wide geographical area of the North Pacific, can be erected.

The data presented in this table synthesizes the information contained in the range charts for each of our sites (Tables 2-6), placing these findings within a magnetostratigraphic framework. The high core-recovery rates, overall quality of radiolarian preservation, high sedimentation rates, nearly continuous records, and excellent magnetostratigraphy at these Leg 145 sites make it possible to examine in detail various radiolarian events across a broad latitudinal and longitudinal band. Ages for these biostratigraphic events were calculated using the magnetostratigraphy from each of the sites, with ages for magnetic events taken from Cande and Kent (1992). These estimated ages are based on the assumption of a constant rate of sedimentation between pairs of magnetic reversal events. Ages of biostratigraphic events located between the core top and the earliest magnetic event were determined using a core top age of $0.00 \mathrm{Ma}$ and interpolating between $0.00 \mathrm{Ma}$ and the age of the youngest identifiable magnetic event. Except for the bottom of Site 881 (see radiolarian site summary for Site 881 ), the ages of biostratigraphic events positioned below the oldest recognized magnetic reversal in a hole were calculated using the sedimentation rate derived from the oldest pair of magnetic events.

We also, in the discussion which follows, compare our estimates of the ages of events with those from other published studies, some of which are listed in the right-hand columns of Table 7. The quality of the stratigraphic control varies widely in these reports from highresolution oxygen isotope stratigraphy (i.e., Hays and Shackleton, 1976; Morley and Shackleton, 1978; Moore et al., 1993; Moore, 1995) to magnetostratigraphy (i.e., Morley, 1985; Johnson et al., 1989; Caulet et al., 1993) to only biostratigraphy (i.e., Kling, 1973; Foreman, 1975; Reynolds, 1980; Sakai, 1980; Wolfart, 1981). Where ages where not estimated for events, we have taken zonal informa- tion, revising it, if necessary, to reflect most recent correlations with respect to specific epoch boundaries. For the data from northwest $\mathrm{Pa}$ cific Site 579A, we reexamined the slides as part of this study and updated the magnetostratigraphy to the Cande and Kent (1992) time scale.

When comparing age estimates for specific radiolarian events listed in Table 7 and discussed in the following section, it is important to note several possible reasons for any age differences. One of the most obvious reasons for age differences is that the particular event is diachronous, taking place at different times in various regions. Dissimilar ages could be the result of significant differences in sample density. Degree and quality of stratigraphic control as well as improper identification of biostratigraphic species and magnetostratigraphic events could also create age differences.

The last abundant appearance of Lychnocanoma nipponica sakaii (Pl. 6, Figs. 1, 4) is recorded at three sites $(881,886$, and 887). Studies of North Pacific piston cores by Robertson (1975), Kruglikova (1976), and Morley et al. (1982) have shown that this event occurs consistently throughout the North Pacific with an estimated age of $\sim 0.05 \mathrm{Ma}$. Spencer-Cervato et al. (1993), however, in their revision of North Pacific datum levels in twelve DSDP sites, list an age of $0.55 \mathrm{Ma}$ for this event (LO of Lychnocanium grande). The APC apparently failed to recover the topmost sediments at Sites 884 and 885 , which would account for the presence of $L$. nipponica sakaii within the upper $0.2 \mathrm{~m}$ of both Holes $884 \mathrm{~B}$ and $885 \mathrm{~A}$.

The LO of Stylacontarium acquilonium (Pl. 3, Figs. 1, 2,4) occurs at or just above the globally synchronous extinction of Stylatractus universus at all five sites. Analysis of high-sedimentation-rate piston cores by Robertson (1975) and Morley et al. (1982) have shown that this event is synchronous in the northwest Pacific with an age of 0.35 $\mathrm{Ma}$. From examination of the sample interval information for our five sites and the presence/absence data in the range charts (Tables 2-6), we arrived at an estimated age of this event in our Leg 145 sites ranging from 0.37 to $0.43 \mathrm{Ma}$. The timing of this event corresponds with that reported for this species throughout the North Pacific (Kling, 1973; Reynolds, 1980; Sakai, 1980; Weaver et al., 1981).

As in other ocean regions, the LO of Stylatractus universus (Pl. 2, Fig. 3) is apparently synchronous throughout the North Pacific, with an estimated age range of $0.5-0.6 \mathrm{Ma}$ based on combining the presence/absence data for this event (Tables 2-6). This age, however, is slightly older than that $(0.45 \mathrm{Ma})$ calculated by correlating the LO of this species with oxygen isotope stratigraphies in piston cores from the Atlantic, Pacific, Indian, and Southern oceans (Hays and Shackleton, 1976; Morley and Shackleton, 1978). It is also older than that reported from eastern equatorial Pacific Leg 138 sites $(0.45-0.46 \mathrm{Ma}$, Moore et al., 1993; Moore, 1995), from northwest Pacific Site 579A (0.47 Ma, this study), from a suite of DSDP North Pacific sites $(0.4$ Ma, Spencer-Cervato et al., 1993), and from low-latitude Indian Ocean sites (0.47 Ma; Caulet et al., 1993). Our data on the timing of this event with respect to the LO of $S$. acquilonium agrees with that of previous studies of North Pacific sediments (Kling, 1973; Reynolds, 1980; Sakai, 1980; Weaver et al., 1981).

Anthocyrtella (?) callopisma (PI. 3, Fig. 3) is not present in samples from Gulf of Alaska Site 887 (northernmost site) and occurs only in a few older levels in western North Pacific Site 884. In the three southern sites drilled on Leg 145, the age of the LO of A.(?) callopisma occurs between 0.52 and $0.91 \mathrm{Ma}$. This range can be narrowed by selecting the age of the oldest of the samples in which this species does not occur and the age of the youngest of the samples containing A. (?) callopisma. Applying this technique, we arrive at a revised age for this event ranging from 0.58 to $0.68 \mathrm{Ma}$. This age estimate is slightly younger than the $0.74 \mathrm{Ma}$ age reported by Caulet (1986b) for this event.

The LO of Eucyrtidium matuyamai (Pl. 5, Fig. 3) is clearly recorded in four of our five sites. At Sites 884, 885, and 887, the youngest samples containing $E$. matuyamai occur directly below the onset of 
Table 7. Radiolarian event chart for North Pacific Sites 881, 884, 885, 886, and 887 .

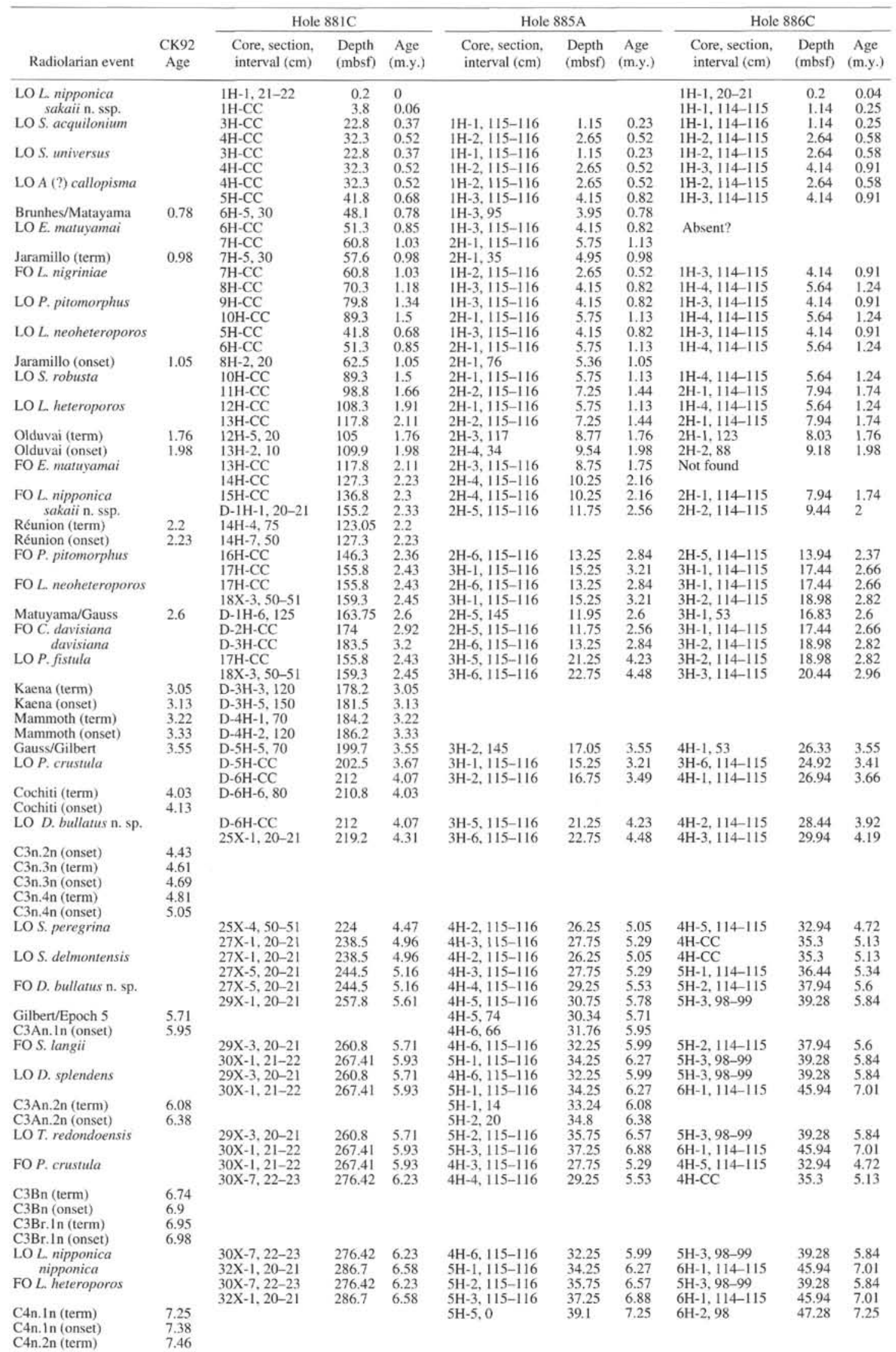


Table 7 (continued).

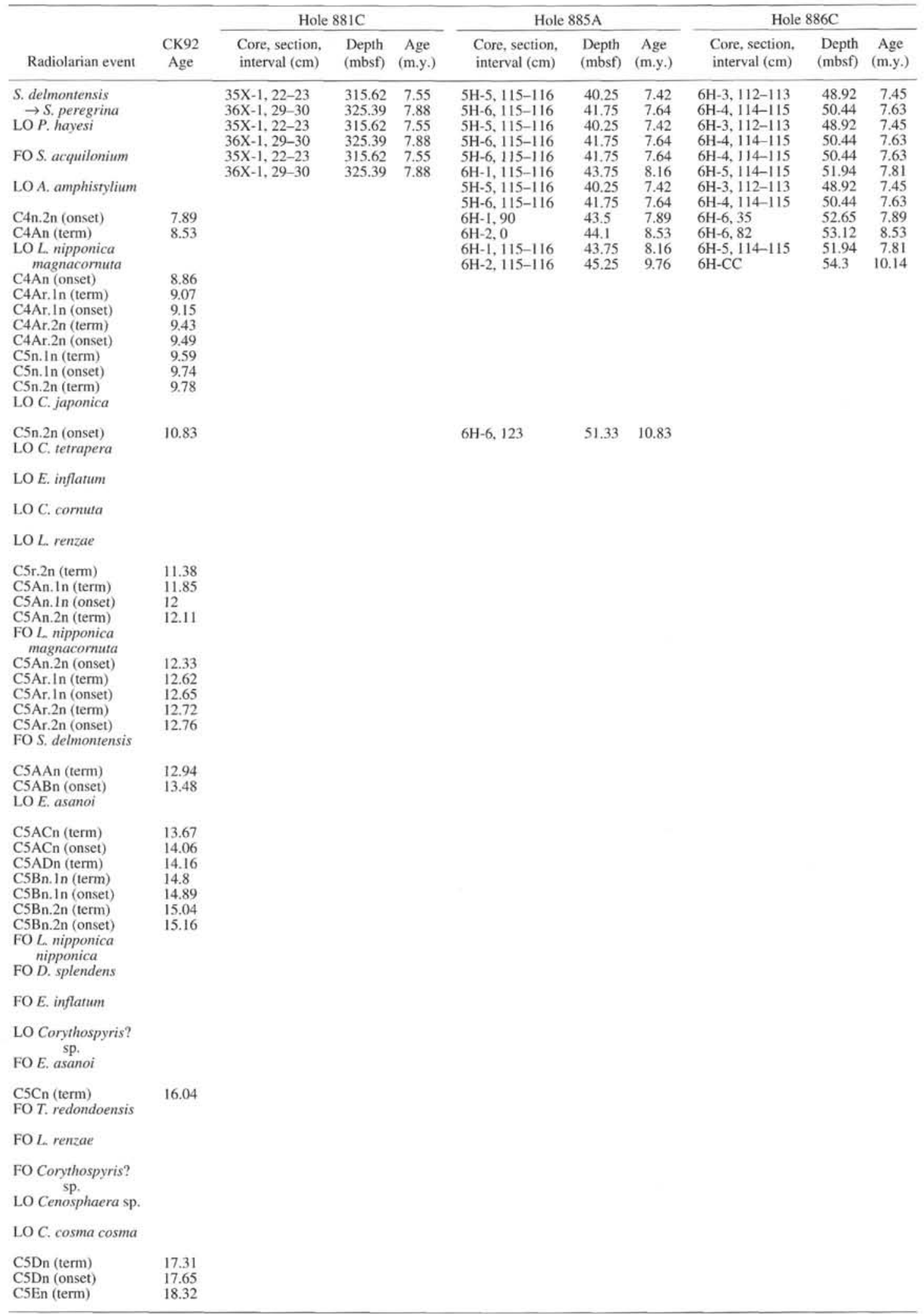

Notes: Left-hand column lists radiolarian event and magnetic reversal. Column second from left (CK92 Age) gives age of magnetic event using Cande and Kent (1992) time scale. Next 15 columns list sample levels that bracket event, depth (mbsf), and age of these levels. Four columns on far right-hand side give age estimates for many of these events derived from information reported from previous studies of radiolarian-bearing sediments in the Pacific: northwest Pacific Site 579 (this study); eastern equatorial Pacific Leg 138 (Moore et al., 1993 [lower half of box when two dates given]; Moore, 1995); central Pacific Leg 85 (Johnson et al., 1989); North Pacific (Spencer-Cervanto et al., 1993). Ages of events revised to conform to Cande and Kent (1992) geochronology. 
Table 7 (continued).

\begin{tabular}{|c|c|c|c|c|c|c|c|c|c|c|}
\hline \multirow[b]{2}{*}{ Radiolarian event } & \multicolumn{3}{|c|}{ Hole 884B } & \multicolumn{3}{|c|}{ Hole 887A } & \multirow[b]{2}{*}{$\begin{array}{c}\text { Pacific } \\
\text { Leg } 86, \\
\text { Hole } 579 \mathrm{~A}\end{array}$} & \multirow[b]{2}{*}{$\begin{array}{r}\text { Pacific } \\
\text { Leg } 138\end{array}$} & \multirow[b]{2}{*}{$\begin{array}{l}\text { Pacific } \\
\text { Leg } 85\end{array}$} & \multirow[b]{2}{*}{$\begin{array}{l}\text { North } \\
\text { Pacific }\end{array}$} \\
\hline & $\begin{array}{l}\text { Core, section, } \\
\text { interval }(\mathrm{cm})\end{array}$ & $\begin{array}{l}\text { Depth } \\
\text { (mbsf) }\end{array}$ & $\begin{array}{c}\text { Age } \\
\text { (m.y.) }\end{array}$ & $\begin{array}{l}\text { Core, section, } \\
\text { interval }(\mathrm{cm})\end{array}$ & $\begin{array}{l}\text { Depth } \\
\text { (mbsf) }\end{array}$ & $\begin{array}{l}\text { Age } \\
\text { (m.y.) }\end{array}$ & & & & \\
\hline LO L. nipponica & & & & $1 \mathrm{H}-1,12-13$ & 0.12 & 0 & & & & 0.55 \\
\hline sakaii $\mathrm{n}$. ssp. & & & & $1 \mathrm{H}-3,52-53$ & 3.52 & 0.06 & & & & \\
\hline \multirow{2}{*}{ LO S. acquilonium } & $2 \mathrm{H}-5,135-136$ & 13.85 & 0.25 & $3 \mathrm{H}-3,132-133$ & 20.52 & 0.35 & & & & \\
\hline & $3 \mathrm{H}-5,135-136$ & 23.35 & 0.43 & $4 \mathrm{H}-1,12-13$ & 25.82 & 0.44 & & & & \\
\hline \multirow{2}{*}{ LO $S$. universus } & $3 \mathrm{H}-5,135-136$ & 23.35 & 0.43 & $4 \mathrm{H}-1,12-13$ & 25.82 & 0.44 & 0.47 & 0.45 & & 0.4 \\
\hline & $\begin{array}{l}4 \mathrm{H}-5,135-136 \\
\text { Too rare }\end{array}$ & 32.85 & 0.6 & $\begin{array}{l}\text { 4H-3, 132-133 } \\
\text { Absent }\end{array}$ & 30.02 & 0.51 & & 0.46 & & \\
\hline Brunhes/Matayama & $5 \mathrm{H}-5,150$ & 42.5 & 0.78 & $6 \mathrm{H}-1,85$ & 45.55 & 0.78 & & 0.78 & & \\
\hline LO E. matuyamai & $\begin{array}{l}6 \mathrm{H}-5,135-136 \\
7 \mathrm{H}-5,135-136\end{array}$ & $\begin{array}{l}51.85 \\
61.35\end{array}$ & 0.93 & $\begin{array}{l}7 \mathrm{H}-3,54-56 \\
7 \mathrm{H}-6,54-56\end{array}$ & $\begin{array}{l}57.74 \\
62.24\end{array}$ & $\begin{array}{l}1.02 \\
1.22\end{array}$ & & & & 1.05 \\
\hline Jaramillo (term) & $7 \mathrm{H}-1,60$ & $54-55.1$ & 0.98 & $7 \mathrm{H}-1.140$ & 55.6 & 0.98 & & 0.91 & & \\
\hline FO L nigriniae & Absent & & & Absent & & & 1.06 & $\begin{array}{l}1.35 \\
1.33\end{array}$ & 1.23 & 0.85 \\
\hline LO P. pitomorphus & $\begin{array}{l}5 \mathrm{H}-5,135-136 \\
6 \mathrm{H}-5,135-136\end{array}$ & $\begin{array}{l}42.35 \\
51.85\end{array}$ & $\begin{array}{l}0.78 \\
0.93\end{array}$ & $\begin{array}{l}5 \mathrm{H}-6,55-56 \\
6 \mathrm{H}-3,54-55\end{array}$ & $\begin{array}{l}43.25 \\
48.24\end{array}$ & $\begin{array}{l}0.74 \\
0.83\end{array}$ & & & & \\
\hline LO L. neoheteroporos & Absent & & & Absent & & & 0.93 & 1.07 & & 0.55 \\
\hline Jaramillo (onset) & 7H- $-3,90$ & 59.4 & 1.05 & $7 \mathrm{H}-4,25$ & 58.95 & 1.05 & & 1.07 & & \\
\hline LOS. robusta & $\begin{array}{l}10 \mathrm{H}-\mathrm{CC} \\
12 \mathrm{X}-1.68-69\end{array}$ & $\begin{array}{l}86.3 \\
87.98\end{array}$ & $\begin{array}{l}1.72 \\
1.76\end{array}$ & $8 \mathrm{H}-3,54-55$ & 67.24 & 1.48 & & & & \\
\hline LO L. heteroporos & $10 \mathrm{H}-\mathrm{CC}$ & $\begin{array}{l}86.3 \\
86.3\end{array}$ & 1.72 & $\begin{array}{l}8 \mathrm{H}-6,54-55 \\
\text { Absent }\end{array}$ & 71.74 & 1.71 & 1.37 & 1.79 & & \\
\hline Olduvai (term) & $12 X-1,68-69$ & 87.98 & 1.76 & & & & & 1.77 & & \\
\hline Olduvai (onset) & $13 \mathrm{X}-3,60$ & 96.9 & 1.98 & & & & & 1.95 & & \\
\hline FO E. matuyamai & $12 X-1,68-69$ & 87.98 & 1.76 & $9 \mathrm{H}-3,54-55$ & 76.74 & 1.97 & & & & 2 \\
\hline $\mathrm{FO} L$ nipponica & $13 \mathrm{X}-3,134-135$ & 97.64 & 2 & $10 \mathrm{H}-3,54-55$ & 86.24 & 2.46 & & & & \\
\hline & $10 \mathrm{H}-\mathrm{CC}$ & 86.3 & 1.72 & $9 \mathrm{H}-3,54-55$ & 76.74 & 1.97 & & & & \\
\hline $\begin{array}{l}\text { sakaii n. ssp. } \\
\text { Réunion (term) }\end{array}$ & $12 \mathrm{X}-1,68-69$ & 87.98 & 1.76 & $10 \mathrm{H}-3,54-55$ & 86.24 & 2.46 & & & & \\
\hline & $\begin{array}{l}14 X-3,110 \\
14 X-4,70\end{array}$ & $\begin{array}{l}107.1 \\
108.2\end{array}$ & $\begin{array}{l}2.2 \\
2.23\end{array}$ & & & & & & & \\
\hline FO P. pitomorphus & $13 \mathrm{X}-3,134-135$ & 97.64 & 2 & $12 \mathrm{H}-6,54-55$ & 109.74 & 3.51 & & & & \\
\hline & $14 X-5,133-134$ & 110.3 & 2.29 & $13 \mathrm{H}-3,54-55$ & 114.74 & 3.75 & & & & \\
\hline FO L neoheteroporos & Absent & & & Absent & & & 2.25 & 3.25 & & \\
\hline Matuyama/Gauss & $15 X-7.30$ & 121.9 & 2.6 & $10 \mathrm{H}-4,20$ & 88.9 & 2.6 & & 2.6 & & \\
\hline FO C. davisiana & $17 X-5,135-136$ & 139.15 & 2.9 & $11 \mathrm{H}-3,54-55$ & 95.74 & 2.85 & 2.82 & 2.71 & & 2.8 \\
\hline davisiana & $18 X-5,135-136$ & 148.85 & 3.06 & $12 \mathrm{H}-3,54-55$ & 105.24 & 3.27 & & & & \\
\hline LO $P$. fistula & $17 X-5,135-136$ & 139.15 & 2.9 & $13 \mathrm{H}-3,54-55$ & 114.74 & 3.75 & & 4.41 & 3.4 & \\
\hline & $18 X-5,135-136$ & 148.85 & 3.06 & $14 \mathrm{H}-3,54-55$ & 124.24 & 4.11 & & 4.39 & & \\
\hline Kaena (term) & $18 \times-4,60$ & 148.1 & 3.05 & I1H- 6,140 & 101.1 & 3.05 & & 3.054 & & \\
\hline Kaena (onset) & $19 X-1,125$ & 152.35 & 3.13 & $12 \mathrm{H}-1,14$ & 101.85 & 3.13 & & 3.127 & & \\
\hline Mammoth (term) & $19 \mathrm{X}-6,100$ & 159.6 & 3.22 & $12 \mathrm{H}-2,100$ & 104.2 & 3.22 & & 3.221 & & \\
\hline Mammoth (onset) & & & & $12 \mathrm{H}-4,35$ & 106.55 & 3.33 & & 3.325 & & \\
\hline $\begin{array}{l}\text { Gauss/Gilbert } \\
\text { LOP. crustula }\end{array}$ & $\begin{array}{l}21 X-6,120 \\
\text { Absent }\end{array}$ & 179.2 & 3.55 & $\begin{array}{l}12 \mathrm{H}-6,115 \\
\text { Absent }\end{array}$ & 110.35 & 3.55 & & & & \\
\hline Cochiti (term) & $26 \mathrm{X}-1,95$ & 219.65 & 4.03 & $14 \mathrm{H}-1,40$ & 121.1 & 4.03 & & 4.188 & & \\
\hline $\begin{array}{l}\text { Cochiti (onset) } \\
\text { LO D. bullatus n. sp. }\end{array}$ & $\begin{array}{l}26 \mathrm{X}-4,100 \\
\text { Absent }\end{array}$ & 224.2 & 4.13 & $\begin{array}{l}14 \mathrm{H}-3,150 \\
\text { Absent }\end{array}$ & 125.2 & 4.13 & & 4.32 & & \\
\hline C3n.2n (onset) & & & & $15 X-4,0$ & 134.7 & 4.43 & & 4.604 & & \\
\hline C3n.3n (term) & $29 X-4,0$ & 252.1 & 4.61 & & & 4.43 & & 4.782 & & \\
\hline C3n.3n (onset) & $30 \mathrm{X}-1,110$ & 258.4 & 4.69 & $16 \mathrm{X}-1,100$ & 142.2 & 4.69 & & 4.88 & & \\
\hline $\mathrm{C} 3 \mathrm{n} .4 \mathrm{n}(\mathrm{term})$ & $30 X-7,50$ & 266.8 & 4.81 & $17 \mathrm{X}-1,70$ & 145.8 & 4.81 & & 4.981 & & \\
\hline C3n.4n (onset) & $31 \mathrm{X}-1,70$ & 276.7 & 5.05 & $17 X-4,35$ & 149.95 & 5.05 & & 5.228 & & \\
\hline LOS. peregrina & $33 \times-4,135-136$ & 292.4 & 5.34 & $20 X-3,54-55$ & 177.64 & 5.94 & 2.97 & 2.69 & 2.78 & 2.9 \\
\hline & $35 \mathrm{X}-1,135-135$ & 307.1 & 5.62 & $21 X-3,54-55$ & 186.74 & 6.39 & & & & \\
\hline LO $S$. delmontensis & $39 X-5,135-136$ & 351.3 & 6.45 & $21 X-3,54-55$ & 186.74 & 6.39 & & & & \\
\hline & $41 \times-5,135-136$ & 370.5 & 6.99 & $22 \mathrm{H}-2,54-55$ & 195.44 & 7.04 & & & & \\
\hline FO D. bullatus n. sp. & Absent & & & Absent & & & & & & \\
\hline Gilbert/Epoch 5 & $35 X-4,135$ & 311.55 & 5.71 & $(19 X-4,110)$ & 169.5 & 5.71 & & 5.875 & & \\
\hline C3An.In (onset) & $37 \mathrm{X}-1,0$ & 325 & 5.95 & $(20 X-3,90)$ & 178 & 5.95 & & 6.122 & & \\
\hline FO S. langii & $29 X-1,135-136$ & 249 & 4.56 & $16 \times-3,55-56$ & 143.25 & 4.73 & & & & 4.95 \\
\hline & $31 \mathrm{X}-5,135-136$ & 274.4 & 4.99 & $17 \mathrm{X}-2,54-55$ & 147.14 & 4.89 & & & & \\
\hline LO D. splendens & $29 \mathrm{X}-1,135-136$ & 249 & 4.56 & $16 \mathrm{X}-3,55-56$ & 143.25 & 4.73 & & & & \\
\hline & $31 \times-5,135-136$ & 274.4 & 4.99 & $17 \mathrm{X}-2,54-55$ & 147.14 & 4.89 & & & & \\
\hline C3An.2n (term) & $38 \mathrm{X}-1,20$ & 334.5 & 6.08 & $(20 X-6,90)$ & 182.5 & 6.08 & & 6.256 & & \\
\hline C 3 An. $2 n$ (onset) & $39 \mathrm{X}-3,110$ & 348 & 6.38 & & & & & 6.555 & & \\
\hline LO T. redondoensis & $29 \mathrm{X}-1,135-136$ & 249 & 4.56 & $17 X-2,54-55$ & 147.14 & 4.89 & & & & \\
\hline FO $P$. crustula & $\begin{array}{l}31 X-5,135-136 \\
\text { Absent }\end{array}$ & 274.4 & 4.99 & $\begin{array}{l}\text { 18X-3, 54-55 } \\
\text { Absent }\end{array}$ & 158.34 & 5.33 & & & & \\
\hline C3Bn (term) & $41 X-1,120$ & 364.3 & 6.74 & & & & & & & \\
\hline C3Bn (onset) & $41 X-4,0$ & 367.6 & 6.9 & & & & & & & \\
\hline C $3 \mathrm{Br} . \ln ($ term) & $41 X-5,0$ & 369.1 & 6.95 & & & & & & & \\
\hline $\mathrm{C} 3 \mathrm{Br}$.In (onset) & $41 X-5,120$ & 370.25 & 6.98 & & & & & & & \\
\hline LO L nipponica & $49 X-5,135-136$ & 447.6 & 9.26 & $24 \mathrm{H}-6,54-55$ & 220.44 & 9.44 & & & & \\
\hline $\begin{array}{l}\text { nipponica } \\
\text { FO } L \text { heteroporos }\end{array}$ & $\begin{array}{l}50 X-5,135-136 \\
\text { Too rare }\end{array}$ & 457.2 & 9.74 & $\begin{array}{l}25 \mathrm{H}-3,54-55 \\
\text { Too rare }\end{array}$ & 225.44 & 10.01 & & 3.29 & & 4.6 \\
\hline C4n.ln (term) & $42 X-2,0$ & 374.2 & 7.25 & & & & & 7.406 & & \\
\hline C4n.1n (onset) & $42 X-5,95$ & 379.65 & 7.38 & $(22 \mathrm{H}-5,60)$ & 200 & 7.38 & & 7.533 & & \\
\hline C $4 n .2 \mathrm{n}(\mathrm{term})$ & $42 \mathrm{X}-6,130$ & 381.5 & 7.46 & $(22 \mathrm{H}-6,10)$ & 201 & 7.46 & & 7.618 & & \\
\hline
\end{tabular}


Table 7 (continued).

\begin{tabular}{|c|c|c|c|c|c|c|c|c|c|c|}
\hline \multirow[b]{2}{*}{ Radiolarian event } & \multicolumn{3}{|c|}{ Hole $884 \mathrm{~B}$} & \multicolumn{3}{|c|}{ Hole $887 \mathrm{~A}$} & & & & \\
\hline & $\begin{array}{l}\text { Core, section, } \\
\text { interval }(\mathrm{cm})\end{array}$ & $\begin{array}{l}\text { Depth } \\
\text { (mbsf) }\end{array}$ & $\begin{array}{l}\text { Age } \\
(\mathrm{m} . \mathrm{y} .)\end{array}$ & $\begin{array}{l}\text { Core, section, } \\
\text { interval }(\mathrm{cm})\end{array}$ & $\begin{array}{l}\text { Depth } \\
\text { (mbsf) }\end{array}$ & $\begin{array}{l}\text { Age } \\
(\mathrm{m.y.})\end{array}$ & $\begin{array}{l}\text { Leg } 86, \\
\text { Hole } 579 \mathrm{~A}\end{array}$ & $\begin{array}{r}\text { Pacific } \\
\text { Leg } 138\end{array}$ & $\begin{array}{l}\text { Pacific } \\
\text { Leg } 85\end{array}$ & $\begin{array}{l}\text { North } \\
\text { Pacific }\end{array}$ \\
\hline S. delmontensis & Not found & & & $22 \mathrm{H}-6,54-55$ & 201.44 & 7.5 & & 6.73 & 6.58 & $6.5-8.4$ \\
\hline$\rightarrow S$. peregrina & & & & $23 \mathrm{H}-6,54-55$ & 210.94 & 8.38 & & 6.69 & & \\
\hline LO P. hayesi & $43 X-5,135-136$ & 389.8 & 7.65 & $22 \mathrm{H}-6,54-55$ & 201.44 & 7.5 & & & & \\
\hline & $45 X-5,135-136$ & 409.1 & 8.2 & $23 \mathrm{H}-6,54-55$ & 210.94 & 8.38 & & & & \\
\hline FO $S$. acquilonium & $43 X-5,135-136$ & 389.8 & 7.65 & $22 \mathrm{H}-6.54-55$ & 201.44 & 7.5 & & & & 4.95 \\
\hline & $45 X-5,135-136$ & 409.1 & 8.2 & $23 \mathrm{H}-6,54-55$ & 210.94 & 8.38 & & & & \\
\hline LO A. amphistylium & $43 X-5,135-136$ & 389.8 & 7.65 & $23 \mathrm{H}-6,54-55$ & 210.94 & 8.38 & & & & \\
\hline & $45 X-5,135-136$ & 409.1 & 8.2 & $24 \mathrm{H}-3,54-55$ & 215.94 & 8.85 & & & & \\
\hline C4n.2n (onset) & $44 X-6,70$ & 400.2 & 7.89 & $(23 \mathrm{H}-3,10)$ & 206 & 7.89 & & 8.027 & & \\
\hline C4An (term) & $46 X-5,115$ & 418.45 & 8.53 & $(24 \mathrm{H}-1,0)$ & 212.4 & 8.53 & & 8.631 & & \\
\hline LO L nipponica & $47 X-5,135-136$ & 428.3 & 8.71 & $23 \mathrm{H}-6,54-55$ & 210.94 & 8.38 & & & & \\
\hline magnacornuta & $48 X-5,135-136$ & 438 & 8.94 & $24 \mathrm{H}-3,54-55$ & 215.94 & 8.85 & & & & \\
\hline $\mathrm{C} 4 \mathrm{An}$ (onset) & $48 X-4,105$ & 436.15 & 8.86 & $(24 \mathrm{H}-3,60)$ & 216 & 8.86 & & 8.945 & & \\
\hline C4Ar. In (term) & $49 \mathrm{X}-1,45$ & 440.65 & 9.07 & & & & & 9.142 & & \\
\hline C4Ar.1n (onset) & $49 \times-4,50$ & 445.2 & 9.15 & & & & & 9.218 & & \\
\hline C4Ar.2n (term) & $50 X-1,130$ & 451.1 & 9.43 & $(24 \mathrm{H}-6,45)$ & 220.35 & 9.43 & & 9.482 & & \\
\hline C4Ar.2n (onset) & $50 \times-3,30$ & 453.1 & 9.49 & (24H-6, 135) & 221.25 & 9.49 & & 9.543 & & \\
\hline C5n.1n (term) & $50 X-3,70$ & 453.5 & 9.59 & $(24 \mathrm{H}-7,50)$ & 221.9 & 9.59 & & 9.639 & & \\
\hline C5n.In (onset) & $50 \times-6,0$ & 457.3 & 9.74 & $(25 \mathrm{H}-2,5)$ & 223.45 & 9.74 & & & & \\
\hline C $5 n .2 n$ (term) & $50 \times-7,50$ & 458.75 & 9.78 & $(25 \mathrm{H}-2,25)$ & 223.65 & 9.78 & & & & \\
\hline LO C. japonica & $51 X-5,135-136$ & 466.7 & 9.97 & $24 \mathrm{H}-6,54-55$ & 220.44 & 9.44 & & 10.1 & 9.7 & 11.15 \\
\hline & $52 \mathrm{X}-5,135-136$ & 476.2 & 10.2 & $25 \mathrm{H}-3,54-55$ & 225.44 & 10.01 & & 10.1 & & \\
\hline C5n.2n (onset) & $55 X-3,25$ & 502.5 & 10.83 & $(26 X-1,60)$ & 232 & 10.83 & & 10.839 & & \\
\hline LO C. tetrapera & $49 X-5,135-136$ & 447.6 & 9.26 & $25 \mathrm{H}-6,54-55$ & 229.94 & 10.57 & & & 12 & 12.05 \\
\hline & $50 X-5,135-136$ & 457.2 & 9.74 & $\mathrm{C}-26 \mathrm{H}-6,55-56$ & 234.35 & 11.24 & & & & \\
\hline LO $E$. inflatum & $56 X-5,135-136$ & 514.8 & 11.52 & $25 \mathrm{H}-6,54-55$ & 229.94 & 10.57 & & & & 12.55 \\
\hline & $57 X-5,137-139$ & 524.5 & 12.24 & C- $26 \mathrm{H}-6,55-56$ & 234.35 & 11.24 & & & & \\
\hline LO C. cornuta & $56 X-5,135-136$ & 514.8 & 11.52 & C $-26 \mathrm{H}-6,55-56$ & 234.35 & 11.24 & & 11.89 & 12 & 12.4 \\
\hline & $57 X-5,137-139$ & 524.5 & 12.24 & C $-27 \mathrm{H}-3,55-56$ & 239.35 & 11.89 & & & & \\
\hline LO L renzae & $56 X-5,135-136$ & 514.8 & 11.52 & C- $26 \mathrm{H}-6,55-56$ & 234.35 & 11.24 & & 11.83 & 12 & 12.55 \\
\hline & $57 X-5,137-139$ & 524.5 & 12.24 & C- $-27 \mathrm{H}-3,55-56$ & 239.35 & 11.89 & & & & \\
\hline C5r.2n (term) & & & & C- $26 \mathrm{H}-6,135$ & 235.15 & 11.38 & & 11.373 & & \\
\hline C5An.1n (term) & $57 X-3,60$ & 520.7 & 11.85 & $\mathrm{C}-27 \mathrm{H}-2,95$ & 238.25 & 11.85 & & 11.841 & & \\
\hline C5An.In (onset) & $57 X-4,50$ & 522.1 & 12 & $\mathrm{C}-27 \mathrm{H}-3,70$ & 239.5 & 12 & & & & \\
\hline C5An.2n (term) & $57 \times-4,140$ & 523 & 12.11 & C- $27 \mathrm{H}-3,125$ & 240.05 & 12.11 & & & & \\
\hline FO L nipponica & $57 X-5,137-139$ & 524.5 & 12.24 & C- $27 \mathrm{H}-3,55-56$ & 239.35 & 11.89 & & & & \\
\hline magnacornuta & $58 X-5,135-136$ & 534.1 & 12.88 & C- $27 \mathrm{H}-6,55-56$ & 243.85 & 12.73 & & & & \\
\hline C5An.2n (onset) & $57 X-6,90$ & 525.5 & 12.33 & $\mathrm{C}-27 \mathrm{H}-4,135$ & 241.65 & 12.33 & & & & \\
\hline C5Ar.In (term) & $58 X-2,30$ & 528.5 & 12.62 & & & & & & & \\
\hline C5Ar.In (onset) & $58 \mathrm{X}-3,30$ & 530 & 12.65 & & & & & & & \\
\hline C $5 \mathrm{Ar} .2 \mathrm{n}$ (term) & $58 \mathrm{X}-3,130$ & 531 & 12.72 & & & & & & & \\
\hline C5Ar.2n (onset) & $58 X-4,130$ & 532.5 & 12.76 & & & & & & & \\
\hline FO S. delmontensis & $58 \times-5,135-136$ & 534.1 & 12.88 & $28 \mathrm{H}-3,54-55$ & 254.24 & 14.49 & & & & \\
\hline & $59 X-5,135-136$ & 543.8 & 13.52 & $28 \mathrm{H}-6,55-56$ & 258.75 & 15.26 & & & & \\
\hline C5AAn (term) & $58 X-6,80$ & 535 & 12.94 & & & & & & & \\
\hline $\mathrm{C} 5 \mathrm{ABn}$ (onset) & $59 X-4,140$ & 542.3 & 13.48 & & & & & & & \\
\hline LO E. asanoi & $59 X-5,135-136$ & 543.8 & 13.52 & $28 \mathrm{H}-3,54-55$ & 254.24 & 14.49 & & & & \\
\hline & $60 \times-5,135-136$ & 553.5 & 13.82 & $28 \mathrm{H}-6,55-56$ & 258.75 & 15.26 & & & & \\
\hline C5 ACn (term) & $60 X-3,90$ & 550 & 13.67 & $(27 \mathrm{H}-6,30)$ & 249 & 13.67 & & & & \\
\hline C5ACn (onset) & $61 X-3,40$ & 559 & 14.06 & $(28 \mathrm{H}-1,70)$ & 251.4 & 14.06 & & & & \\
\hline C5ADn (term) & & & & $(28 \mathrm{H}-2,20)$ & 252.4 & 14.16 & & & & \\
\hline $\mathrm{C} 5 \mathrm{Bn} . \ln$ (term) & & & & $(28 \mathrm{H}-4,80)$ & 256 & 14.8 & & & & \\
\hline C5Bn. In (onset) & & & & $(28 \mathrm{H}-5,30)$ & 257 & 14.89 & & & & \\
\hline C5Bn.2n (term) & & & & $(28 \mathrm{H}-5,80)$ & 257.5 & 15.04 & & & & \\
\hline C5Bn.2n (onset) & & & & $(28 \mathrm{H}-6,0)$ & 258.2 & 15.16 & & & & \\
\hline FO L nipponica & $57 X-5,137-139$ & 524.5 & 12.24 & $28 \mathrm{H}-6,55-56$ & 258.75 & 15.26 & & & & \\
\hline nipponica & $58 X-5,135-136$ & 534.1 & 12.88 & $29 \mathrm{H}-3,54-55$ & 263.74 & 16.27 & & & & \\
\hline FO D. splendens & $61 \times-5,135-136$ & 563 & 14.44 & $28 \mathrm{H}-6,55-56$ & 258.75 & 15.26 & & & & \\
\hline & $62 X-5,135-136$ & 572.7 & 15.35 & $29 \mathrm{H}-3,54-55$ & 263.74 & 16.27 & & & & \\
\hline FO $E$. inflatum & $61 X-5,135-136$ & 563 & 14.44 & $28 \mathrm{H}-6,55-56$ & 258.75 & 15.26 & & & & 13.25 \\
\hline & $62 X-5,135-136$ & 572.7 & 15.35 & $29 \mathrm{H}-3,54-55$ & 263.74 & 16.27 & & & & \\
\hline LO Corythospyris? & $61 X-5,135-136$ & 563 & 14.44 & $28 \mathrm{H}-6,55-56$ & 258.75 & 15.26 & & & & \\
\hline sp. & $62 X-5,135-136$ & 572.7 & 15.35 & $29 \mathrm{H}-3,54-55$ & 263.74 & 16.27 & & & & \\
\hline FO E. asanoi & $62 X-5,135-136$ & 572.7 & 15.35 & $28 \mathrm{H}-6,55-56$ & 258.75 & 15.26 & & & & \\
\hline & $63 X-5,135-136$ & 582.2 & 16.24 & $29 \mathrm{H}-3,54-55$ & 263.74 & 16.27 & & & & \\
\hline C5Cn (term) & $63 X-4,70$ & 580 & 16.04 & $(29 \mathrm{H}-2,130)$ & 263 & 16.04 & & & & \\
\hline FO $T$, redondoensis & $63 X-5,135-136$ & 582.2 & 16.24 & $28 \mathrm{H}-6,55-56$ & 258.75 & 15.26 & & & & \\
\hline & $64 X-4,135-136$ & 590.3 & 16.96 & $29 \mathrm{H}-3,54-55$ & 263.74 & 16.27 & & & & \\
\hline FO L renzae & $61 X-5,135-136$ & 563 & 14.44 & $29 \mathrm{H}-3,54-55$ & 263.74 & 16.27 & & & & \\
\hline & $62 X-5,135-136$ & 572.7 & 15.35 & $\mathrm{C}-30 \mathrm{H}-3,54-55$ & 267.84 & 17.51 & & & & \\
\hline FO Corythospyris? & $63 X-5,135-136$ & 582.2 & 16.24 & $29 \mathrm{H}-3,54-55$ & 263.74 & 16.27 & & & & \\
\hline sp. & $64 X-4,135-136$ & 590.3 & 16.96 & $\mathrm{C}-30 \mathrm{H}-3,54-55$ & 267.84 & 17.51 & & & & \\
\hline LO Cenosphaera sp. & $63 \times-5,135-136$ & 582.2 & 16.24 & $29 \mathrm{H}-3,54-55$ & 263.74 & 16.27 & & & & \\
\hline & $64 X-4,135-136$ & 590.3 & 16.96 & $\mathrm{C}-30 \mathrm{H}-3,54-55$ & 267.84 & 17.51 & & & & \\
\hline LO C. cosma cosma & $64 X-4,135-136$ & 590.3 & 16.96 & $29 \mathrm{H}-3,54-55$ & 263.74 & 16.27 & & & & \\
\hline & $65 X-5,135-136$ & 601.5 & 18.09 & $\mathrm{C}-30 \mathrm{H}-3,54-55$ & 267.84 & 17.51 & & & & \\
\hline C5Dn (term) & $65 X-1,10$ & 594.2 & 17.31 & $(29 \mathrm{H}-5,80)$ & 267 & 17.31 & & & & \\
\hline C5Dn (onset) & $65 X-4,40$ & 599 & 17.65 & C $-30 \mathrm{H}-3,110$ & 268.4 & 17.65 & & & & \\
\hline C5En (term) & $65 X-6,120$ & 602.8 & 18.32 & C $-30 \mathrm{H}-6,15$ & 271.95 & 18.32 & & & & \\
\hline
\end{tabular}


the Jaramillo Subchron (1.05 Ma). At Site 881, the youngest sample in which E. matuyamai is present falls just above the onset of the Jaramillo. If we combine the presence/absence data shown in the range charts for these four sites (Tables $2-4,6$ ), we arrive at an estimate of $1.0 \mathrm{Ma}$ for the age of this event. At Site 886, the entire Jaramillo Subchron was not detected in Hole 886C, which may explain why $E$. matuyamai was found in only a single sample from this hole. The timing of this event recorded at the Leg 145 sites agrees with that reported previously in western North Pacific sediments (Foreman, 1975; Kellogg and Hays, 1975; Reynolds, 1980; Sakai, 1980; Morley, 1985), in eastern North Pacific sequences (Kling, 1973; Wolfart, 1981) and in California sections (Weaver et al., 1981). It is also similar to the average age for LO of E. matuyamai in North Pacific sites reported by Spencer-Cervato et al. (1993).

Lamprocyrtis nigriniae (Pl. 7, Fig. 9) only occurs in the three southern Leg 145 sites. The estimated age of this species' FO ranges from 0.52 to $1.24 \mathrm{Ma}$. This range encompasses age estimates for this event computed from data presented in other studies of sediment records from the eastern (Kling, 1973; Weaver et al., 1981; Wolfart, 1981), western (Foreman, 1975; Reynolds, 1980; Sakai, 1980) and entire (Spencer-Cervato et al., 1993) North Pacific. The upper limit of our range is similar to that reported for this event in the low-latitude Indian (1.11 Ma; Caulet et al., 1993), and central Pacific (1.23 $\mathrm{Ma}$; Johnson et al., 1989) oceans, as well as at latitudes $<40^{\circ} \mathrm{N}$ in the western North Pacific (1.06 Ma, this study) Ocean. Our age estimate is, however, somewhat younger than the age (1.33-1.35 Ma) calculated for this species' FO in the eastern equatorial Pacific (Moore et al., 1993; Moore, 1995).

The LO of Lamprocyrtis neoheteroporos (PI. 7, Fig. 7) is only recorded in the three southern sites $(881,885$, and 886$)$, with an estimated age of $0.85 \mathrm{Ma}$. This age estimate is younger than that given by Moore et al. (1993) and Moore (1995) for this event (1.07 Ma) in eastern equatorial Pacific Leg 138 sites, by Caulet et al. (1993) for the low-latitude Indian Ocean (1.18 Ma), and by Reynolds (1980) in western North Pacific Leg 57 sites (LO of L. neoheteroporos coincides with LO of Eucyrtidium matuyamai, $1.0 \mathrm{Ma}$ ). However, it is similar to the estimated age of this event of $0.93 \mathrm{Ma}$ calculated from our studies of closely spaced samples from northwest Pacific Site 579, as well as that reported by Kling (1973) and Wolfart (1981) for the LO of L. neoheteroporos in records from the eastern North Pacific (LO of L. neoheteroporos occurs in the lower part of the Stylatractus universus Zone). The timing of this event in sediments from our Leg 145 sites is older than the age given for it in the western North Pacific by Foreman (1975; LO of $L$. neoheteroporos near the middle of $S$. universus Zone, $\sim 0.7 \mathrm{Ma}$ ) and Sakai (1980; LO of L. neoheteroporos near top of $S$. universus Zone, $\sim 0.45 \mathrm{Ma}$ ), in California sections by Weaver et al. (1981, 0.58 Ma), and across the entire North Pacific (0.55 Ma) as averaged by Spencer-Cervato et al. (1993).

The LO of Sphaeropyle robusta (Pl. 1, Figs. 6, 7) occurs just above the termination of the Olduvai Subchron in all five Leg 145 sites. In four of the five sites, all except for Site 885, the age appears to range from $\sim 1.5$ to $1.7 \mathrm{Ma}$. Morley (1985) also reported the LO of this species between the Jaramillo and Olduvai Subchrons in the northwest Pacific Leg 86 sites. The timing of this event (in the lower part of the Eucyrtidium matuyamai Zone) is similar to that previously reported from western North Pacific DSDP sites (Foreman, 1975; Reynolds, 1980; Sakai, 1980). Kling (1973), however, placed the LO of $S$. robusta in the uppermost Lamprocyrtis heteroporos Zone before the FO of E. matuyamai. Kling's older estimate for this event may reflect differences in defining characteristics of this species.

Lamprocyrtis heteroporos (PI. 7, Figs. 5, 8) occurs in only two samples from Gulf of Alaska Site 887 and in only four levels in our other northern site (884). Even at these low abundances, it appears as if this species' LO was recorded in all of the sites we examined with the exception of Site 887. In three of the four sites that record this event, the youngest sample containing $L$. heteroporos is positioned directly above the termination of the Olduvai Subchron (1.76 Ma). At
Site 881 , the youngest sample in which this species is present falls below the onset of the Olduvai Subchron (1.98 Ma). The estimated age of this event ranges from $\sim 1.3$ to $2.0 \mathrm{Ma}$ based on the combined presence/absence data in the range charts for this species (Tables 2-5). This age range in high-latitude North Pacific sediments encompasses most other estimates for this event in other regions of the world's oceans. In the eastern North Pacific, Kling's (1973) and Wolfart's (1981) data place this event near the middle of the Eucyrtidium matuyamai Zone ( 1.5 Ma). Weaver et al. (1981) published an age of 1.65 Ma for this event in sediments from Californian sections. A wide range of values has been published for the $\mathrm{LO}$ of $L$. heteroporos in western North Pacific sediments. Sakai (1980) shows this event near the base of the Stylatractus universus Zone $(\sim 0.9 \mathrm{Ma})$ in studies of sediments from DSDP Leg 56 material off Japan. Other western North Pacific studies, however, indicate a much older age for this event, with Foreman (1975) reporting the LO of L. heteroporos as occurring near the middle of the E. matuyamai Zone ( 1.4 Ma). Reynolds (1980), in his examination of western Pacific records from DSDP Leg 57, placed this event just below the LO of E. matuyamai $(\sim 2.0 \mathrm{Ma})$. We calculated an age of $1.37 \mathrm{Ma}$ for this event in western North Pacific Site 579 positioned just south $\left(39^{\circ} \mathrm{N}\right)$ of our Leg 145 sites. In eastern equatorial Leg 138 sites, Moore et al. (1993) and Moore (1995) give an age of $1.79 \mathrm{Ma}$ for this event.

If data from Site 886 is included even though Eucyrtidium matuyamai (Pl. 5, Fig. 3) is present in only a single sample, then all five Leg 145 sites record the FO of this species near the base of the Olduvai Subchron (1.98 Ma). By combining the presence/absence information for this event from these five sites, we estimate an age for this species' FO at between 1.9 and 2.1 Ma. This age is similar to that published by others who have examined sediments from various regions of the North Pacific and from California (Kling, 1973; Foreman, 1975; Reynolds, 1980; Sakai, 1980; Wolfart, 1981; Weaver et al., 1981; Spencer-Cervato et al., 1993).

Lamprocyrtis neoheteroporos (Pl. 7, Fig. 7) is present only in the three southern sites drilled during Leg 145. The oldest sample containing this species at all three sites is positioned near the Matuyama/ Gauss boundary. If we combine the presence/absence data for $L$. neoheteroporos from the range charts for these three sites (Tables 2, 4, 5 ), we estimate that the age of the $\mathrm{FO}$ of this species ranges from $\sim 2.45$ to $3.0 \mathrm{Ma}$. Our estimate for this event in Leg 145 sites is older than that reported in most other studies. In the eastern North Pacific, Kling (1973) and Wolfart (1981) reported this event as occurring in the middle of the Eucyrtidium matuyamai Zone ( 1.35 Ma). In the western North Pacific, Foreman (1975) documented the gradual evolutionary development of this species from the upper part of the Lamprocyrtis heteroporos Zone into the middle of the E. matuyamai Zone. Sakai (1980) positioned the FO of $L$. neoheteroporos at the base of the E. matuyamai Zone $(\sim 2.0 \mathrm{Ma})$ in his range chart.

We have examined material from northwest Pacific Site 579 (Leg $86)$ situated just south $\left(39^{\circ} \mathrm{N}\right)$ of Leg $145^{\prime}$ 's southernmost sites and computed an estimated age of $2.25 \mathrm{Ma}$ for this event. Caulet et al. (1993) reported a similar age of 2.34 Ma for this species' FO in sediments from the low-latitude Indian Ocean. The only published older age for the FO of $L$. neoheteroporos comes from the Leg 138 studies (Moore et al., 1993; Moore, 1995), where an estimated age of 3.25 Ma was determined for this event.

The FO of Cycladophora davisiana davisiana (PI. 4, Figs. 3, 4) is distinctly recorded in North Pacific sediments. In the three Leg 145 sites $(881,884$, and 887$)$ that record the Kaena Subchron, the oldest sample in which this species is present falls just above the Kaena termination (3.05 Ma). From examination of our sample interval and the presence/absence data for this event in the range charts (Tables 2-6), we estimate that $C$. davisiana davisiana first occurred in the North Pacific between $\sim 2.75$ and $3.0 \mathrm{Ma}$.

Our estimated age range for this event is similar to that in DSDP Leg 86 sediments from Hole $579 \mathrm{~A}$, directly south of our sites, where we have computed an age of $2.82 \mathrm{Ma}$ for the $\mathrm{FO}$ of $\mathrm{C}$. davisiana davi- 
siana. In North Pacific sediments at DSDP Legs 56 and 57 off Japan, Sakai (1980) and Reynolds (1980) placed this event in the lower half of the Lamprocyrtis heteroporos Zone, slightly older than the FO of Lamprocyrtis neoheteroporos. The $\mathrm{FO}$ of $C$. davisiana davisiana occurs at the base of the $L$. heteroporos Zone in eastern North Pacific Leg 18 sites (Kling, 1973). In their revision of radiolarian events, Spencer-Cervato et al. (1993) published an age of $2.8 \mathrm{Ma}$ averaged using data from seven North Pacific DSDP sites. Moore et al. (1993) and Moore (1995) report an age of $2.71 \mathrm{Ma}$ for this species' FO in eastern equatorial Pacific sediments. A younger age of $2.55 \mathrm{Ma}$ has been given by Caulet et al. (1993) for this event in low-latitude sediments from the Indian Ocean.

Present only in the southern three North Pacific sites, Dictyophimus bullatus (Pl. 4, Figs. 5, 9, 10) has a short range $(\sim 4.2-5.6 \mathrm{Ma})$ centered about the Miocene/Pliocene boundary. From examination of our sample interval and the presence/absence data in our range charts for these sites (Tables 2, 4,5), we calculated an estimated age of $\sim 4.2$ Ma for the LO of D. bullatus.

Stichocorys peregrina ( $\mathrm{Pl}$. 6, Figs. 2, 3) is not as abundant in highlatitude sites as it is in the mid- and low-latitude sites. In Leg 145 sites the LO of $S$. peregrina is diachronous. In the three southern Sites 881 , 885 , and 886 , our best estimate of the age of this event is between 4.9 and 5.1 Ma. In the Gulf of Alaska site (887), the youngest sample in which this species is present has an estimated age of $6.4 \mathrm{Ma}$; whereas, in the western high-latitude North Pacific at Site 884, the youngest sample containing $S$. peregrina is of latest Miocene age ( 5.6 Ma). Thus, it appears that $S$. peregrina disappeared from the Gulf of Alaska first, then from the western high-latitude North Pacific, before becoming extinct in the earliest Pliocene at the three southern sites drilled during Leg 145.

Our age estimates for the LO of $S$. peregrina are older than those reported for this event in other areas of the North Pacific and the Indian Ocean. The nearest age to our estimate for this event comes from the work of Weaver et al. (1981) who estimated an age of $4.6 \mathrm{Ma}$ for this event in California sequences. In marine sediments off California, both Kling (1973) and Wolfart (1981) show the LO of S. peregrina taking place during the Pliocene. Kling lists this event just above the LO of Cycladophora davisiana davisiana. In the western North Pacific east of Japan, studies of sediments from four DSDP legs (Foreman, 1975; Reynolds, 1980; Sakai, 1980; Morley, 1985) all give an age of $\sim 2.9 \mathrm{Ma}$ for the LO of $S$. peregrina, with the placement of LO of $S$. peregrina in the late Pliocene defining the base of the Lamprocyrtis heteroporos Zone. From data provided by Alexandrovich (1992), we have calculated an age of $\sim 3.75 \mathrm{Ma}$ for the LO of $S$. peregrina in Japan Sea sediments. Calculated ages for this event in the eastern equatorial Pacific (ODP Leg 138; Moore et al., 1993; Moore, 1995), in the central Pacific (DSDP Leg 85; Johnson et al., 1989), and in the low-latitude Indian Ocean (Caulet et al., 1993) range from 2.69 to $2.78 \mathrm{Ma}$. Spencer-Cervato et al. (1993) give an average age of $2.9 \mathrm{Ma}$ for the LO of S. peregrina in their recalibration of radiolarian events in a series of mid- and low-latitude North Pacific DSDP sites.

As with Stichocorys peregrina, Stichocorys delmontensis (PI. 6, Fig. 5) is not as abundant in high-latitude sediments as it is in midand low-latitude sequences. The LO of $S$. delmontensis appears to be diachronous across the North Pacific. Combining the presence/absence data for this species for the three southern Leg 145 sites (Tables $2,4,5$ ), the age of this event ranges between 4.9 and 5.1 Ma. In our northern Sites 884 and 887 , however, we estimate the age of the LO of $S$. delmontensis to range from 6.4 to $7.0 \mathrm{Ma}$.

Other studies have also shown that the age of this event in Pacific sediments is quite variable. The youngest age estimates for the LO of S. delmontensis are apparently recorded in western North Pacific sediments where this datum level occurs in the early Pliocene within the upper half of the Sphaeropyle langii Zone (Foreman, 1975; Reynolds, 1980; Sakai, 1980). Both Kling (1973) and Wolfart (1981) re- port an older age for this event, placing it in the late Miocene slightly below the Miocene/Pliocene boundary within the Stichocorys peregrina Zone. Weaver et al. (1981) also have the LO of S. delmontensis occurring in Californian sequences within the $S$. peregrina Zone at 6.2 Ma. From data published by Alexandrovich (1992) for this event, we estimate the LO of $S$. delmontensis in Japan Sea sediments at $\sim 6.8$ Ma.

As stated previously, Dictyophimus bullatus (PI. 4, Figs. 5, 9, 10) is not present in our northern two sites ( 884 and 887 ). In our three southern sites $(881,885$, and 886), the oldest sample in which this species is present appears to be positioned directly above the termination of magnetic event C3An. In (Gilbert/Epoch 5 boundary, 5.71 Ma). Combining the presence/absence data for this species in our three southern sites (Tables 2, 4,5) enables us to narrow the range of the estimated age for the first appearance of this species in the North Pacific to between 5.60 and $5.61 \mathrm{Ma}$.

Although present consistently in the younger portion of the record at all five Leg 145 sites, Sphaeropyle langii (Pl. 2, Figs. 2, 5, 7) is found very sporadically around the time of its FO in high-latitude North Pacific sediments. Foreman (1975) used this event in defining the base of her Sphaeropyle langii Zone, a North Pacific radiolarian zone covering much of the early Pliocene.

Data from Leg 145 indicate that not only is the FO of this species not distinctly recorded in high-latitude North Pacific sediments, but that this event is most likely diachronous and, therefore, its use as a zonal marker is questionable. In the southern three Leg 145 sites, our combined presence/absence data from our range charts (Tables 2, 4, 5 ) indicate that this event occurred between 5.8 and $6.0 \mathrm{Ma}$. The age of this species' FO in northern Sites 884 and 887 appears to take place one million years later, with combined presence/absence data from the range charts for these sites (Tables 2,6 ) centering on an age $\sim 4.8$ Ma.

Our two age estimates for the FO of $S$. langii bracket those reported in studies of marine sediments from the western North Pacific south of our sites (Foreman, 1975; Reynolds, 1980; Sakai, 1980), which place this event at or just below the Miocene/Pliocene boundary. It appears that this event occurred earlier in Japan Sea sediments (Alexandrovich, 1992), where we have calculated an age of $3.2 \mathrm{Ma}$ for this datum level. Spencer-Cervato et al. (1993), in their study of mid- and low-latitude North Pacific DSDP sites, arrived at an age of $4.95 \mathrm{Ma}$ for the FO of $S$. langii.

Dictyophimus splendens (Pl. 7, Figs. 3, 4) was first described by Campbell and Clark (1944) in California Miocene sequences. More recently, Caulet (1986b) has reported this species' LO in lower Pliocene sediments from the subantarctic, whereas C. Nigrini (unpubl, data, 1994) gives an age between 4.6 and 4.9 Ma for this event in the Central Indian Basin.

Although diachronous, D. splendens occurs in all five Leg 145 sites. At Site 885 , the youngest sample in which this species is present falls within magnetic event C3An. $2 n(6.08-6.38 \mathrm{Ma})$. When we combine the presence/absence information on the range charts for our three southern North Pacific sites (Tables 2, 4, 5), we arrive at an estimated age of 5.95 Ma for this event, disregarding data from Site 886 because of a $4.5 \mathrm{~m}$ gap in the sediment record from Core 5 of Hole $886 \mathrm{C}$. In our two northern sites ( 884 and 887 ), the youngest sample containing D. splendens occurs within magnetic event C $3 \mathrm{n} .4 \mathrm{n}(4.81-$ $5.05 \mathrm{Ma}$ ). The estimated age of $\sim 4.8 \mathrm{Ma}$ for the timing of this event at high-latitude North Pacific Sites 884 and 887 is comparable to that reported by Caulet (1986b) and Nigrini (unpubl. data) in subantarctic and low-latitude Indian Ocean sediments, respectively.

The LO of Theocorys redondoensis (PI. 7, Figs. 1,2,6) is diachronous in Leg 145 sites. In the two high-latitude northern sites (884 and 887 ), the youngest sample in which $T$. redondoensis is present occurs within (Site 884 ) or directly below (Site 887 ) magnetic event C $3 \mathrm{n} .4 \mathrm{n}$ (4.81-5.05 Ma). If we combine the presence/absence data for this event from the range charts (Tables 2,6) for these two sites, we 
arrive at an age of $\sim 4.9 \mathrm{Ma}$ in our two northernmost sites. In our three sites to the south, the estimated age of this event ranges from 5.71 to $7.01 \mathrm{Ma}$. However, this is artificially too old because of the nonrecovery of about $4.5 \mathrm{~m}$ of sediment in the bottom of Core 145-886C$5 \mathrm{H}$. If we discard the information from Site 886, the ages for this event at the remaining two sites ( 881 and 885 ) still do not coincide, with a younger date $(\sim 5.8 \mathrm{Ma})$ recorded in the western (Site 881 ) North Pacific compared to the computed date (6.6-6.9 Ma) for this event in the central North Pacific (Site 885).

Age estimates for this event published previously all support the diachronous nature of the LO of T. redondoensis in Pacific sediments. Kling (1973) and Wolfart (1981) both placed this datum just below the Miocene/Pliocene boundary $(\sim 5.3-5.4 \mathrm{Ma})$ in eastern North Pacific sediments from DSDP Legs 19 and 63, respectively. Further to the east, Weaver et al. (1981) reported an age of $\sim 7.0 \mathrm{Ma}$ for this event in sediment sequences from California. In western North Pacific sediments from DSDP Leg 57, Reynolds (1980) showed this event occurring in the early Pliocene (lower part of the Sphaeropyle langii Zone).

The LO of Lychnocanoma nipponica nipponica (Pl. 5, Figs. 4, 5) is accurately recorded in all Leg 145 sites except for Site 886. Although an apparent level for this event can be determined in sediments from Site 886, it is of questionable use because only the upper half $(\sim 4.5 \mathrm{~m})$ of the core barrel of Core $145-886 \mathrm{C}-5 \mathrm{H}$ retained cored sediment, creating a gap of approximately $4.5 \mathrm{~m}$ in the sediment record from this site. The youngest sample containing this species at Site 885 falls within magnetic event C3An.2n (6.08-6.38 Ma). If we combine the presence/absence data for this event contained in the range charts for southern Sites 881 and 885 (Tables 2, 4), we arrive at an age estimate of $\sim 6.25 \mathrm{Ma}$. The $\mathrm{LO}$ of $L$. nipponica nipponica in our two northern Leg 145 sites (884 and 887) is much older, with a range between 9.26 and $10.01 \mathrm{Ma}$. We can narrow the range of this event in our northern two sites by selecting the age of the oldest sample where L. nipponica nipponica is absent $(9.44 \mathrm{Ma})$ and the age of the youngest sample containing this species (9.74 Ma), arriving at an estimated age for this event of $\sim 9.6 \mathrm{Ma}$.

Previous studies support the data presented above, indicating that the LO of L. nipponica nipponica is diachronous, with this species evidently existing longer at lower latitudes. In analyses of DSDP Leg 56 sediments from the western North Pacific off Japan, Sakai (1980) listed the disappearance of this species in his radiolarian events table just before the FO of Stylacontarium acquilonium. Alexandrovich (1992) reported the LO of L. nipponica nipponica in Japan Sea sediments just above the LO of Stichocorys delmontensis in the upper part of the late Miocene. Although Sakai placed these two events within the early Pliocene portion of the Sphaeropyle langii Zone, our study when combined with the results of Alexandrovich (1992) strongly suggests that these events occurred somewhat older in the late Miocene. Reynolds (1980) lists a late Pliocene age for this event in western Pacific Leg 57 sediments, with the LO of Lychnocanium grande (which we consider to be $L$. nipponica nipponica) occurring in his table of radiolarian datums between the LO of Stichocorys peregrina and the FO of Cycladophora davisiana davisiana.

The presence of Lamprocyrtis heteroporos (Pl. 7, Figs. 5, 8) in many of the samples immediately above the supposedly first recorded presence is so sporadic in Sites 884 and 887 that information from these Leg 145 northern sites is inadequate for definitive placement of its FO. This event is evident in the three southern sites that have higher abundances of $L$. heteroporos. At Site 885 , the oldest sample containing this species is positioned between the termination of magnetic event $\mathrm{C} 4 \mathrm{n} .1 \mathrm{n}(7.25 \mathrm{Ma})$ and the onset of magnetic event C3An.2n (6.38 Ma). Information regarding this event in Site 886 is somewhat misleading because Core $145-886 \mathrm{C}-5 \mathrm{H}$ did not recover sediment below the upper $4.5 \mathrm{~m}$ of the core barrel. If we use only the data pertaining to the FO of $L$. heteroporos from Sites 881 and 885 , we arrive at an estimated age of $6.6 \mathrm{Ma}$ for this event.

In most cases, our estimated age for the FO of $L$. heteroporos is significantly older than previously reported in North Pacific sedi- ments. In the western North Pacific, Foreman (1975) and Reynolds (1980) place this event slightly above the Miocene/Pliocene boundary within the Sphaeropyle langii Zone. Sakai (1980), in his study of DSDP Leg 56 sediments off Japan, also had the FO of $L$. heteroporos occurring within the $S$. langii Zone, but with a somewhat younger age. Examination of the range chart for DSDP Leg 86 Site 578 (Morley, 1985) indicates that at least at this northwestern Pacific site, $L$. heteroporos extended into the upper Miocene. In the eastern North Pacific, Kling (1973) places this event within the latest Miocene just below the Miocene/Pliocene boundary, whereas Wolfart (1981) shows it coinciding with the Miocene/Pliocene boundary. In California sections, Weaver et al. (1981) also positioned the FO of $L$. heteroporos close to the Miocene/Pliocene boundary. Spencer-Cervato et al. (1993) give an age of 4.6 Ma for this event in their revision of radiolarian datum levels in DSDP sites situated across the mid- and low-latitude North Pacific. The youngest age for the FO of $L$. heteroporos is that reported for eastern equatorial Pacific sediments, where Moore et al. (1993) and Moore (1995) calculated an age for the FO of L. heteroporos of $3.29 \mathrm{Ma}$.

The radiolarian assemblage in four of the five Leg 145 sites shows a sharp definitive change in dominance from Stichocorys delmontensis to Stichocorys peregrina. The intermittent occurrences of $S$. peregrina in sediments from Site 884 make it difficult to locate precisely this change in dominance. This shift in dominance most likely occurs within magnetic event $\mathrm{C} 4 \mathrm{n} .2 \mathrm{n}(7.46-7.89 \mathrm{Ma})$. If we combine the presence/absence data for this event shown in our range charts for these four sites (Tables 2, 4-6), we can narrow the estimated age range to between 7.55 and $7.63 \mathrm{Ma}$.

Our estimated age of this dominance shift in Leg 145 sediments is slightly older than the ages of 6.69 Ma (Moore et al., 1993) and 6.73 Ma (Moore, 1995) calculated from eastern equatorial Pacific Leg 138 sites, 6.58 Ma computed from data in central Pacific sites (Johnson et al., 1989), and 6.8 Ma (Weaver et al., 1981) reported from studies of Californian Miocene sections. In DSDP Leg 63 sediments from the eastern North Pacific, Wolfart (1981) reported this switch in dominance as occurring in the middle of the late Miocene. In western North Pacific sediments, Foreman (1975), Reynolds (1980), and Sakai (1980) place this shift in major abundance in the late Miocene near the base of the Stichocorys peregrina Zone. Spencer-Cervato et al. (1993) give a range of between 6.5 and $8.4 \mathrm{Ma}$ in their recalibration of North Pacific radiolarian events.

Chen (1975b) first described Prunopyle hayesi (Pl. 2, Figs. 1, 4) in Antarctic sediments from DSDP Leg 28 sites. The range of this species in the Southern Ocean extends from the early Miocene into the late Miocene (Chen, 1975a, 1975b). Although it is not found in every sample, $P$. hayesi is present in samples from all five Leg 145 sites. In the four sites with good magnetic reversal stratigraphy throughout this interval, the youngest sample containing $P$. hayesi occurs just above (Sites 885 and 886 ) or below (Sites 884 and 887 ) the onset of magnetic event $\mathrm{C} 4 \mathrm{n} .2 \mathrm{n}(7.89 \mathrm{Ma})$. We have calculated an estimated age of $7.6 \mathrm{Ma}$ for this event by combining the presence/absence data from the range charts for all five Leg 145 sites (Tables 2 6). Our estimated late Miocene age for this event is comparable to that reported by Chen (1975a).

The FO of Stylacontarium acquilonium (Pl. 3, Figs. 1, 2, 4) occurs in all five Leg 145 sites, with the oldest sample in which this species is present falling within magnetic event C4n.2n (7.46-7.89 Ma). From examination of our sample interval and the presence/absence charts from all five sites (Tables 2-6), we estimate the age of the FO of $S$. acquilonium between 7.65 and $7.81 \mathrm{Ma}$ in the high-latitude North Pacific. This event, along with the dominance change between $S$. delmontensis and $S$. peregrina, forms a definitive marker for the middle late Miocene in North Pacific sediments.

Kling (1973) in the eastern North Pacific and Reynolds (1980) in the western North Pacific both placed this event within the upper portion of the Stichocorys peregrina Zone in the latest Miocene. Sakai (1980), however, reported a younger age for the FO of S. acquilonium in DSDP Leg 56 sediments off Japan, placing it within the early 
Pliocene of the Sphaeropyle langii Zone. Spencer-Cervato et al. (1993), in their revised calibration of North Pacific events, show the $\mathrm{FO}$ of $S$. acquilonium occurring in the early Pliocene with an age of $\sim 4.95 \mathrm{Ma}$.

Ling (1973) reported finding Amphymenium sp. in DSDP Leg 19 Miocene sediments from the North Pacific and the Bering Sea. Amphymenium amphistylium (Pl. 1, Figs. 8, 9) was present sporadically throughout the Miocene sequences recovered at all Leg 145 sites except Site 881 . In all four sites where A. amphistylium was found except the Gulf of Alaska site (887), the youngest sample containing this species falls just above or below the onset of magnetic event C4n.2n (7.89 Ma). By combining the presencelabsence data on the range charts for Sites 884,885 , and 886 (Tables 3-5) we can derive an age estimate of $\sim 7.65 \mathrm{Ma}$ for this event. At Site 887 , this event has a range between 8.38 and $8.85 \mathrm{Ma}$. Our results show that apparently A. amphistylium disappeared from the eastern North Pacific (Site 887) about one million years before its LO in the western North Pacific.

The LO of Lychnocanoma nipponica magnacornuta (Pl. 5, Figs. 1,2 ) forms a distinct stratigraphic datum in Leg 145 sediments. In the two northern sites ( 884 and 887 ) whose sediments clearly record the onset of magnetic event C4An (8.86 Ma), the youngest sample in which L. nipponica magnacornuta is present occurs either just above or just below this magnetic reversal. In southern Sites 885 and 886 , radiolarian-bearing sequences and sediments that clearly record magnetic reversals do not extend below the upper 45 and $55 \mathrm{~m}$, respectively. At these southern sites the youngest sample containing this species is below the oldest recorded magnetic event (C4n termination; $8.53 \mathrm{Ma}$ ).

Excluding the southern two sites because they have no magnetic control to bracket this event, we have computed an estimated age of $8.8 \mathrm{Ma}$ for the LO of L. nipponica magnacornuta, based on the presence/absence data from the range charts for Sites 884 and 887 (Tables 3, 6). In DSDP Leg 57 sediments off Japan, Sakai (1980) listed the LO of L. nipponica magnacornuta in his radiolarian events table as coinciding with the top of the Didymocyrtis antepenultima Zone $(\sim 7.8 \mathrm{Ma})$. This may indicate that this species disappeared from the high-latitude North Pacific 1 m.y. before it vanished from the western Pacific off Japan.

The LO of Cyrtocapsella japonica (PI. 3, Fig. 7) has an estimated age of $\sim 10.0 \mathrm{Ma}$. based on the combined presence/absence data in the range charts from both Sites 884 and 887 (Tables 3, 6). At both of these Leg 145 sites, the youngest sample containing this species occurs within magnetic event C5n.2n (9.78-10.83 Ma). Our estimated age for the LO of $C$. japonica is similar to most other dates computed for this event around the Pacific: 10.1 Ma from Leg 138 sites in the eastern equatorial Pacific (Moore et al., 1993; Moore, 1995), 9.7 Ma from Leg 85 sites in the central Pacific (Johnson et al., 1989), and 11.5 Ma from the Miocene sections of California (Weaver et al., 1981). In the western North Pacific off Japan, both Reynolds (1980) and (Sakai, 1980) report the LO of $C$. japonica as occurring near the middle Miocene/late Miocene boundary within the Diartus pettersso$n i$ Zone. In eastern North Pacific DSDP sites this event appears to occur somewhat later, with Kling (1973) and Wolfart (1981) placing the LO of $C$. japonica within the Didymocyrtis antepenultima Zone. The oldest published age for this event in North Pacific sediments is 11.15 Ma given by Spencer-Cervato et al. (1993) from their reevaluation of radiolarian datum levels in mid- and low-latitude DSDP sites.

The LO of Cyrtocapsella tetrapera (Pl. 3, Fig. 6) appears to be diachronous. At Site 887, the youngest sample to contain this species falls between the onset of magnetic event C $5 \mathrm{n} .2 \mathrm{n}(10.83 \mathrm{Ma})$ and the termination of magnetic event C $5 \mathrm{r} .2 \mathrm{n}(11.38 \mathrm{Ma})$. However, at Site 884 , the youngest occurrence of $C$. tetrapera is followed by several samples where this species was not found. Therefore, we had to decide which of these two levels (one between 9.26 and $9.74 \mathrm{Ma}$, and another between 11.57 and $12.24 \mathrm{Ma}$ ) marked the LO of $C$. tetrapera.
For purposes of this discussion, we have selected the youngest of these two choices, which places this event in sediments from Site 884 within magnetic event C5n. In (9.59-9.74 Ma).

Our results appear to confirm findings of previous studies which show that the LO of $C$. tetrapera does not occur at the same time throughout the North Pacific. Weaver et al. (1981) give an age of 11.8 $\mathrm{Ma}$ for this event in Miocene California sections. Both Johnson et al. (1989) and Spencer-Cervato et al. (1993) report an age of $\sim 12.0 \mathrm{Ma}$ for the LO of $C$. tetrapera in sediments from central Pacific DSDP sites and from several DSDP sites located across the mid- and lowlatitude North Pacific, respectively. In eastern North Pacific sediments, Kling (1973) and Wolfart (1981) both show this event occurring within the late Miocene Didymocyrtis antepenultima Zone, somewhat younger than our estimated ages. Data from DSDP sites off Japan indicate that the LO of C. tetrapera took place in the middle Miocene, with Reynolds (1980) positioning this event within the Diartus petterssoni Zone and Sakai (1980) locating it somewhat older in the Dorcadospyris alata Zone.

The LO of Eucyrtidium inflatum (Pl. 4, Fig. 11) falls within magnetic event C5An.2n (12.11-12.33 Ma) at our high-latitude western Site 884. In Gulf of Alaska Site 887, this event apparently occurs one million years later, with the youngest sample containing this species positioned between the onset of magnetic event C $5 n .2 n(10.83 \mathrm{Ma})$ and the termination of magnetic event C5r.2n (11.38 Ma).

In North Pacific sediments off California, E. inflatum apparently survives for several million years after disappearing from the highlatitude North Pacific, with both Kling (1973) and Wolfart (1981) finding the LO of this species centered about the boundary between the Diartus petterssoni and Didymocyrtis antepenultima Zones. Weaver et al. (1981), however, reported an age for this event of 11.8 $\mathrm{Ma}$ in California Miocene sections. In western North Pacific sediments off Japan, Reynolds (1980), and Sakai (1980) both placed this event within the upper half of the Dorcadospyris alata Zone just below the LO of Lithopera renzae. Funayama (1988) showed the LO of E. inflatum occurring in Japanese Miocene sediments within the diatom Denticulopsis praedimorpha Zone (coincides with the lower portion of the radiolarian $D$. petterssoni Zone) at the same time as the LO of $L$. renzae. In revising the ages of published North Pacific radiolarian events, Spencer-Cervato et al. (1993) gave an age of $12.55 \mathrm{Ma}$ for the disappearance of $E$. inflatum.

The LO of Cyrtocapsella cornuta (Pl. 3, Fig. 8) is recorded in both northern Leg 145 sites. The youngest sample from eastern Site 887 containing this species falls within magnetic event C5n. In (11.85$12.0 \mathrm{Ma}$ ). At Site 884 , the youngest sample in which $C$. cornuta is present occurs within the C5An.2n magnetic event (12.11-12.33 Ma). From examination of our sample interval and the presence/absence data in our range charts (Tables 3,6 ), we estimate the age of this event at $\sim 11.7 \mathrm{Ma}$

This age is similar to that reported for the eastern equatorial $\mathrm{Pa}$ cific (11.89 Ma; Moore, 1995) and the central Pacific (12.0 Ma; Johnson et al., 1989). Our age estimate, however, is younger than that computed for the LO of C. cornuta in sediments from Miocene sequences of California ( 13.0 Ma; Weaver et al., 1981) and in DSDP Leg 56 sediments off Japan (upper half of the Dorcadospyris alata Zone; Sakai, 1980). Reynolds (1980), in his study of western North Pacific sediments, lists a younger age for this event, placing it in the middle Miocene within the lower half of the Diartus petterssoni Zone. In their recent reexamination of radiolarian events in North Pacific DSDP records, Spencer-Cervato et al. (1993) published an estimated age of $12.4 \mathrm{Ma}$ for the LO of $C$. cornuta. Our estimated age for this event is older than that given for eastern North Pacific sediments, where both Kling (1973) and Wolfart (1981) show the LO of C. cornuta occurring in the late Miocene (within the Didymocyrtis antepenultima Zone),

Although Sanfilippo et al. (1985) originally stated that Lithopera renzae (Pl. 3, Fig. 5) was confined to latitudes lower than $40^{\circ}$, Leg 
145 samples from $>50^{\circ} \mathrm{N}$ contain this species. At Site 887 , the youngest sample with $L$. renzae occurs just below the termination of magnetic event C5An.1n (11.85 Ma). The youngest sample containing this species at Site 884 is positioned within magnetic event C5An. $2 \mathrm{n}$ (12.11-12.33 Ma). By combining the data from both Sites 884 and 887 in their respective range charts (Tables 3,6 ), we can narrow the range of the estimated age of this event to between 11.52 and 11.89 Ma.

Our estimated age is very similar to that calculated for the LO of L. renzae in Leg 138 sediments from the eastern equatorial Pacific (11.83 Ma; Moore, 1995) and Leg 85 sediments from the central Pacific (12.0 Ma; Johnson et al., 1989). Wolfart (1981), in his analyses of eastern North Pacific sediments off California, positioned this event slightly above the early Miocene/middle Miocene boundary. Also in the eastern North Pacific, Kling (1973) reported the LO of $L$. renzae as occurring near the middle of the radiolarian Diartus petterssoni Zone. In the western Pacific, Reynolds (1980) placed this event in the lower half of the $D$. petterssoni Zone. Also in the western Pacific, Sakai (1980) found that the LO of $L$. renzae was positioned between the FO of Lychnocanoma nipponica magnacornuta and the LO of Crytocapsella cornuta, similar to where it occurs in our radiolarian events chart (Table 7). In siliceous Miocene sequences from Japan, Funayama (1988) placed this event in the middle of the diatom Denticulopsis praedimorpha Zone, coinciding with the lower part of the D. petterssoni Zone. Spencer-Cervato et al. (1993), in their revision of North Pacific datum levels, arrived at a slightly older age of $12.55 \mathrm{Ma}$ for this event.

The FO of Lychnocanoma nipponica magnacormuta (PI. 5, Figs. 1,2 ) is clearly recorded in sediments from Sites 884 and 887 . The oldest sample at Site 884 containing this species falls within magnetic event C5An.2n (12.11-12.33 Ma). At Site 887, the oldest sediments containing $L$. nipponica magnacornuta occur within magnetic event C5An.In (11.85-12.0 Ma). If we combine presence/absence data for this event from our range charts (Tables 3,6), we can narrow the estimated age of this event to between 12.24 and 12.73 Ma. Our estimated age for this event $(\sim 12.5 \mathrm{Ma})$ brackets other published times for the FO of $L$. nipponica magnacornuta. In sediments from DSDP Leg 56 Sites off eastern Japan, Sakai (1980) placed this event directly below the LO of Lithopera renzae in the upper half of the Dorcadospyris alata Zone which is older than our estimate. Funayama (1988) reported this event in Japanese Miocene sections from Noto Peninsula as occurring in the uppermost diatom Denticulopsis praedimorpha Zone, coinciding with the radiolarian Diartus petterssoni Zone.

Stichocorys delmontensis (PI. 6, Fig. 5) is not consistently present in samples from Sites 884 and 887 . This species is much less abundant in the high-latitude North Pacific compared with the low- and mid-latitude Pacific. In western North Pacific Site 884, the oldest sample in which this species is present occurs within the lower half of Chron C5A between the onset of magnetic event C5Ar.2n (12.76 $\mathrm{Ma}$ ) and the termination of magnetic event C5AAn (12.94 Ma). In eastern North Pacific Site 887, the oldest sample to contain S. delmontensis is positioned between the terminations of magnetic events C5ADn (14.16 Ma) and C5Bn.1n (14.80 Ma). These ages are similar to that proposed by Kling (1973) who listed this event as occurring in the early middle Miocene (Dorcadospyris alata Zone) in eastern North Pacific sediments. However, they are much younger than those reported for this event by Reynolds (1980) in the western North Pacific and by Sanfilippo et al. (1985) in the low-latitude Pacific. Both of these latter studies place the FO of $S$. delmontensis in the lower part of the early Miocene.

Eucyrtidium asanoi (Pl. 4, Figs. 6, 7) has a relatively short range with distinct upper and lower limits in Leg 145 sediments. Based on the combined presence/absence data of this species in the range charts for our North Pacific sites (Tables 3,6), the range of E. asanoi extends from approximately 14 to $15.8 \mathrm{Ma}$. At Site 887 , the youngest sample to contain this species occurs between the onset of magnetic event $\mathrm{C} 5 \mathrm{Bn} .2 \mathrm{n}(15.16 \mathrm{Ma})$ and the termination of magnetic event $\mathrm{C} 5 \mathrm{Cn}(16.04 \mathrm{Ma})$. At Site 884 , the LO of E. asanoi is recorded in a sample that falls within magnetic event C5ACn (13.67-14.06 Ma). Based on the estimated ages of our sample intervals and the presence/ absence data for this species listed in our range charts (Tables 3,6), it appears that E. asanoi disappeared from the high-latitude eastern North Pacific $\sim 1$ m.y. before its LO in the high-latitude western North Pacific (14.9 vs. 13.7 Ma).

Our age estimate for the LO of E. asanoi throughout the high-latitude North Pacific is older than that reported from Japanese Miocene sediments by Funayama (1988) who placed this event in the uppermost diatom Crucidenticula nicobarica Zone, coinciding with the uppermost part of the radiolarian Dorcadospyris alata Zone. Sakai (1980), on the other hand, presented data which positions the LO of E. asanoi somewhat older in DSDP Leg 56 (western North Pacific) sediments, where he shows this event coinciding with the LO of Eucyrtidium inflatum within the D. alata Zone. Weaver et al. (1981) also gives an older age than that of Funayama (1988) for this event, with the top of their Eucyrtidium cienkowskii group (which, from their illustrations, we think is E. asanoi) occurring in Miocene sediments from California at approximately $13.3 \mathrm{Ma}$.

The FO of Lychnocanoma nipponica nipponica (Pl. 5, Figs. 4, 5) appears to be diachronous, based on our Leg 145 results. In the western North Pacific at Site 884, the oldest sample in which this species is present occurs within magnetic event C5An.2n (12.11-12.33 Ma). In sediments from Gulf of Alaska Site 887, however, this species first occurs much older in the record, with the oldest sample in which $L$. nipponica nipponica is present bracketed by the onset of magnetic event $\mathrm{C} 5 \mathrm{Bn} .2 \mathrm{n}(15.16 \mathrm{Ma})$ and the termination of magnetic event C5Cn (16.04 Ma). The timing of this event in western North Pacific Leg 56 sediments is approximately midway between our estimated ages for the FO of L. nipponica nipponica, occurring near the middle of the Dorcadospyris alata Zone (Sakai, 1980). In studies of Leg 57 sediments from this same region, however, Reynolds (1980) reported the FO of Lychnocanium grande (which we consider to be L. nipponica nipponica) as occurring somewhat older, near the early Miocene/ middle Miocene boundary.

The FO of Dictyophimus splendens (Pl. 7, Figs. 3, 4) is apparently isochronous in high-latitude North Pacific sediments. At Site 884 in the western North Pacific, the oldest sample with this species falls between the onset of magnetic event $\mathrm{C} 5 \mathrm{ACn}(14.06 \mathrm{Ma})$ and the termination of magnetic event C5Cn (16.04 Ma). In Gulf of Alaska Site 887 , the oldest $D$. splendens is recorded in a sample positioned between the onset of magnetic event C $5 \mathrm{Bn} .2 \mathrm{n}(15.16 \mathrm{Ma})$ and the termination of magnetic event C5Cn (16.04 Ma). Our estimates from both North Pacific sites place the FO of $D$. splendens in the early middle Miocene at $15.3 \mathrm{Ma}$.

The estimated age of the FO of Eucyrtidium inflatum (Pl. 4, Fig. 11) ranges from 14.44 to $16.27 \mathrm{Ma}$ in Leg 145 sediments. The sample with the $\mathrm{FO}$ of $E$. inflatum in western North Pacific Site 884 falls between the onset of magnetic event C5ACn (14.06 Ma) and the termination of magnetic event $\mathrm{C} 5 \mathrm{Cn}(16.04 \mathrm{Ma})$. At Site 887 in the Gulf of Alaska, the oldest sample containing this species occurs between the onset of magnetic event $\mathrm{C} 5 \mathrm{Bn} .2 \mathrm{n}(15.16 \mathrm{Ma})$ and the termination of magnetic event C5Cn (16.04 Ma).

We can narrow the estimated age of this event by noting the age of the oldest sample where $E$. inflatum is present $(15.26 \mathrm{Ma})$ and the age of the youngest sample where this species is absent (15.35 Ma). Most previous studies of this species in North Pacific sediments (Kling, 1973; Reynolds, 1980; Sakai, 1980; Wolfart, 1981; SpencerCervato et al., 1993) as well as in Miocene sequences from Japan (Funayama, 1988) have reported the FO of E. inflatum as occurring somewhere within the Dorcadospyris alata Zone. Both Sakai (1980), in his study of DSDP Leg sediments from the western North Pacific, and Funayama (1988), in his analysis of the Miocene from Japan's 
Noto Peninsula, place this event slightly above the FO of E. asanoi. However, Funayama (1988) has this event taking place in the diatom Denticulopsis hyalina Zone (coinciding with upper part of radiolarian D. alata Zone), whereas Sakai (1980) positions this species' first appearance in the middle of the $D$. alata Zone. In the eastern North Pacific, Wolfart (1981) also shows the FO of E. inflatum occurring near the middle of the $D$. alata Zone. Our estimated age for this event in the high-latitude North Pacific ( 15.3 Ma) compares more favorably with that of Reynolds (1980) in analyses of western Pacific DSDP Leg 57 sediments, where he shows the FO of $E$. inflatum occurring at the base of the $D$. alata Zone near the early Miocene/middle Miocene boundary. The youngest age for this event $(\sim 13.25 \mathrm{Ma})$ is that published by Spencer-Cervato et al. (1993) in their summary paper on North Pacific radiolarian events.

Ling (1973) identified specimens in DSDP Leg 19 sediments that he referred to as "Acanthodesmid" sp. Similar forms were also present in our Leg 145 Miocene material. We tentatively have assigned the name of Corythospyris? sp. (PI. 2, Fig. 8) to this species, which has a short, but distinct range $(\sim 15-17 \mathrm{Ma})$ bracketing the late early Miocene to early middle Miocene period. At Site 884, the youngest sample containing this species falls between the onset of magnetic event C5 ACn (14.06 Ma) and the termination of magnetic event C5Cn (16.04 Ma). At Site 887 in the high-latitude eastern North Pacific, the only sample in which Corythospyris? sp. is present occurs between the termination of magnetic events C5Cn (16.04 Ma) and C5Dn (17.31 Ma). Based on the presencelabsence data at Sites 884 and 887 , the estimated age of the LO of this species can be narrowed to between 15.26 and $15.35 \mathrm{Ma}$.

Sediments from Sites 884 and 887 clearly record the FO of Eucyrtidium asanoi (Pl. 4, Figs. 6, 7). In the western North Pacific at Site 884 , the first sample in which $E$. asanoi is present is located between the onset of magnetic event $\mathrm{C} 5 \mathrm{ACn}(14.06 \mathrm{Ma})$ and the termination of magnetic event C5Cn (16.04 Ma). In Gulf of Alaska Site 887, the oldest sample identified with this species occurs between the onset of magnetic event C. $5 \mathrm{Bn} .2 \mathrm{n}(15.16 \mathrm{Ma})$ and the termination of magnetic event C5Cn (16.04 Ma).

Combining the presence/absence data of this species in our two North Pacific sites enables us to narrow the range of the estimated age for the FO of this species to between 15.35 and 16.24 Ma. In his study of DSDP Leg 56 sediments, Sakai (1980) reported the FO of $E$. asanoi as occurring in the lower part of the Dorcadospyris alata Zone $(\sim 15.0 \mathrm{Ma})$. Funayama (1988) gives a slightly older ( 15.3 Ma) age for this event from his study of the Miocene section from Japan's Noto Peninsula, placing it within the upper portion of the diatom Denticulopsis lauta Zone (lowermost radiolarian Dorcadospyris alata Zone). These data indicate that $E$. asanoi first occurred throughout the western and high-latitude North Pacific at about the same time.

The FO of Theocorys redondoensis (PI. 7, Figs. 1, 2, 6) in the eastern North Pacific (Gulf of Alaska Site 887) falls between the onset of magnetic event $\mathrm{C} 5 \mathrm{Bn} .2 \mathrm{n}(15.16 \mathrm{Ma})$ and the termination of magnetic event C5Cn (16.04 Ma). The oldest sample in which this species is present in Site 884 sediments is positioned between the terminations of magnetic events C5Cn (16.04 Ma) and C5Dn (17.31 Ma). We have narrowed the estimated age of this event by selecting the age of the oldest sample where $T$. redondoensis is present $(16.24 \mathrm{Ma})$ and the age of the youngest sample where this species is absent (16.27 Ma), arriving at an estimated age of $\sim 16.25 \mathrm{Ma}$.

Reynolds (1980) placed the FO of $T$. redondoensis much earlier in Miocene western North Pacific sediments (above the FO of Didymocyrtis violina which Sanfilippo et al. [1985] list as occurring at the base of the Stichocorys delmontensis Zone [ 21 Ma]) than our age estimated for this event in the high-latitude North Pacific. In the eastern North Pacific, Kling (1973) and Wolfart (1981) reported the FO of this species as taking place within the Dorcadospyris alata Zone ( 13-15.5 Ma). Weaver et al. (1981) give an age of $\sim 13.5 \mathrm{Ma}$ for this event in Californian Miocene sequences.
Our data indicates that the FO of Lithopera renzae (Pl. 3, Fig. 5) is diachronous in the high-latitude North Pacific. In sediments from western North Pacific Site 884, the oldest sample containing this species falls between the onset of magnetic event C5ACn (14.06 Ma) and the termination of magnetic event C5Cn (16.04 Ma). However, in Gulf of Alaska Site 887, the oldest sample in which $L$. renzae is present is positioned between the termination of magnetic events C5Cn (16.04 Ma) and C5Dn (17.31 Ma).

Reynolds (1980), Wolfart (1981), and Sanfilippo et al. (1985) all place the FO of this species near the early Miocene/middle Miocene boundary ( 16.0 Ma). Kling (1973) placed this event just below the FO of $T$. redondoensis in his list of radiolarian events in sediments from eastern North Pacific DSDP Site 173. Funayama (1988) reported this event in Miocene sediments from the Noto Peninsula of Japan as occurring in the uppermost Calocycletta costata Zone. Our estimate for this event in the high latitude eastern North Pacific brackets those given by these other studies.

The FO of Corythospyris? sp. (Pl. 2, Fig. 8) appears to be isochronous in the high-latitude North Pacific. The oldest sample in Sites 884 and 887 to contain this species occurs between the terminations of magnetic events C5Cn (16.04 Ma) and C5Dn (17.31 Ma). Based on the estimated ages of samples from our Leg 145 sites located on either side of this event, we estimate its age to range between 16.27 and $16.96 \mathrm{Ma}$.

The apparent timing of the LO of Cenosphaera sp. (Pl. 1, Fig. 2) is identical in eastern and western high-latitude North Pacific sediments. Because of the high degree of dissolution that coincides with this event, we are not convinced that the effects of dissolution created what appears to be the LO of this robust-shelled species. The youngest sample from Site 884 containing Cenosphaera sp. is positioned between the terminations of magnetic events $\mathrm{C} 5 \mathrm{Cn}(16.04 \mathrm{Ma})$ and C5Dn (17.31 Ma). In sediments from Gulf of Alaska Site 887, the youngest sample in which this species is present occurs within of magnetic event C5Dn (17.31-17.65 Ma). From examination of our sample interval and the presence/absence data in our range charts (Tables 3, 6), our best estimate of the timing of the LO of Cenosphaera sp. is approximately $16.7 \mathrm{Ma}$.

The FO of Cycladophora cosma cosma (Pl. 4, Fig. 2) also appears to be isochronous in the high-latitude North Pacific. At both Sites 884 and 887 , the oldest sample to contain $C$. cosma cosma occurs between the terminations of magnetic events C5Cn (16.04 Ma) and C5Dn $(17.31 \mathrm{Ma})$. By combining the data on this event in our range charts (Tables 3,6), we can narrow the estimated age of this event to between 16.96 and $17.51 \mathrm{Ma}$.

\section{SUMMARY}

This study is the first comprehensive study of the Miocene to Pleistocene radiolarian assemblage in the high-latitude North Pacific. The abundance and distribution of 39 taxa were determined in five Leg 145 sites. Except for central Pacific Sites 885 and 886 where radiolarian preservation was generally good throughout the late Pliocene and Pleistocene, radiolarians were only well preserved in sediments $<2 \mathrm{Ma}$ in age. Radiolarian concentrations (number of radiolarians/gram) in the two far northern sites, from the Detroit Seamount in the west (884), and from the Gulf of Alaska in the east (887), are highest throughout the middle Miocene (Fig. 2). All five sites show a concentration maximum of various degrees between 0.75 and 1.5 Ma (mid-Pleistocene). The three southern sites ( 881 , 885 , and 886 ) record another radiolarian maximum between 2.0 and $2.5 \mathrm{Ma}$ that is equal in magnitude to the mid-Pleistocene concentration peak.

The five Leg 145 sites contained a nearly continuous Miocene through Pleistocene record of siliceous sedimentation in addition to a nearly complete magnetic reversal stratigraphy. Thus, not only were 
we able to examine various radiolarian events across a wide latitudinal and longitudinal band, but we also were able to derive an accurate estimate of the age of each event (Tables 7, 8). Many of these events have been recorded in marine sediments from other areas; therefore, our data should provide an excellent compilation of radiolarian events for revision and updating of radiolarian stratigraphy.

\section{SYSTEMATICS}

The systematics of the radiolarians recorded in Leg 145 sediments is presented in two parts:

1. Taxonomic notes: descriptions of new species and revision or emendations to previously published descriptions.

2. Species list: bibliographic references for well-known taxa that are not discussed in the taxonomic notes.

The only literature references given are to the original description and to our present concept of the species, if different from the original one. Type specimens are deposited in the United States National Museum, Washington, D.C.

\section{Taxonomic Notes}

Amphymenium amphistylium Haeckel emend. Morley and Nigrini (Pl. 1, Figs. 8, 9)

Amphymenium amphistylium Haeckel, 1887, p. 520, pl. 44, fig. 9 Amphymenium sp., Ling, 1973, p. 780, pl. 1, figs. 11, 12

Description. Shell with two opposite pored chambered arms arising from a central structure composed of a single spherical medullary shell and an irregular cortical shell. Arms increase in diameter distally, as few as 7, but generally 9 to 13 ; chambers bearing randomly placed subcircular pores on each arm; surface rough with occasional thornlike projections. Shell may become spongy at the distal end of the arms. Termination blunt, but in some specimens there are strong pyramidal terminal spines at the end of each arm. The central structure and the proximal chambers on each arm are surrounded and partly obscured by a spongy cylindrical patagium. There may also be an outer pored, spindle-shaped patagium surrounding all but the last 1 to 3 chambers and constricted distally so as to join the main part of the shell. Surface of secondary patagium smooth.

Haeckel (1887) described this form as having only 7 chambers on each arm and he did not describe the outer patagium.

Dimensions (based on 20 specimens). Maximum length of shell $=190$ $290 \mu \mathrm{m}$; maximum width of arms $=34-60 \mu \mathrm{m}$; minimum breadth of arms, excluding patagium $=20-30 \mu \mathrm{m}$; breadth of arms, including patagium $=50-52$ $\mu \mathrm{m}$.

Table 8. Radiolarian events in North Pacific Leg 145 sediments.

\begin{tabular}{|c|c|c|c|c|c|}
\hline Event & Species & Age $(\mathrm{Ma})$ & & & \\
\hline \multicolumn{6}{|c|}{ Age of isochronous North Pacific events: } \\
\hline LO & Lychnocanoma nipponica sakait & 0.05 & & & \\
\hline LO & Stylacontarium acquilonium & 0.4 & & & \\
\hline LO & Stylatractus universus & 0.55 & & & \\
\hline LO & Amthocyrtella(?) callopisma & 0.62 & & & \\
\hline LO & Lamprocyrtis neoheteroporos & 0.85 & & & \\
\hline LO & Eucyrtidium matuyamai & 1.0 & & & \\
\hline LO & Sphaeropyle robusta & $1.5-1.7$ & & & \\
\hline FO & Eucyrtidium matuyamai & 2.0 & & & \\
\hline FO & Cycladophora davisiana davisiana & 2.9 & & & \\
\hline LO & Dictyophimus bullatus & 4.2 & & & \\
\hline FO & Dictyophimus bullatus & 5.6 & & & \\
\hline \multirow[t]{2}{*}{ FO } & Lamprocyrtis heteroporos & 6.6 & & & \\
\hline & $S$. delmontensis $\rightarrow S$. peregrina & 7.55 & & & \\
\hline LO & Prunopyle hayesi & 7.6 & & & \\
\hline FO & Stylacontarium acquilonium & 7.7 & & & \\
\hline LO & Lychnocanoma nipponica magnacornuta & 8.8 & & & \\
\hline LO & Cyrtocapsella japonica & 10.0 & & & \\
\hline LO & Crytocapsella cornuta & 11.7 & & & \\
\hline LO & Lithopera renzae & 11.7 & & & \\
\hline FO & Lychnocanoma nipponica magnacornuta & 12.5 & & & \\
\hline FO & Dictyophimus splendens & 15.3 & & & \\
\hline FO & Eucyrtidium inflatum & 15.3 & & & \\
\hline LO & Corythospyris? sp. & 15.3 & & & \\
\hline FO & Eucyrtidium asanoi & 15.8 & & & \\
\hline FO & Theocorys redondoensis & 16.25 & & & \\
\hline FO & Corythospyris? sp. & 16.7 & & & \\
\hline LO & Cenosphaera sp. & 16.7 & & & \\
\hline \multirow[t]{3}{*}{ FO } & Cycladophora cosma cosma & 17.25 & & & \\
\hline & & \multicolumn{4}{|c|}{ Age (Ma) } \\
\hline & & \multicolumn{2}{|c|}{ Southern sites } & \multicolumn{2}{|c|}{ Northern sites } \\
\hline Event & Species & $\begin{array}{l}\text { West } \\
(881)\end{array}$ & $\begin{array}{c}\text { Central } \\
(885 / 886)\end{array}$ & $\begin{array}{l}\text { West } \\
(884)\end{array}$ & $\begin{array}{l}\text { East } \\
(887)\end{array}$ \\
\hline \multicolumn{6}{|c|}{ Age of diachronous North Pacific events: } \\
\hline LO & Stichocorys peregrina & 5.0 & & $5.6-6.4$ & \\
\hline FO & Sphaeropyle langii & $5.8-6.0$ & & 4.8 & \\
\hline LO & Dictyophimus splendens & 5.95 & & 4.8 & \\
\hline LO & Theocorys redondoensis & $5.8-6.75$ & & 4.9 & \\
\hline LO & L. nipponica nipponica & 6.25 & & 9.6 & \\
\hline LO & Stichocorys delmontensis & 5.0 & & 6.7 & \\
\hline LO & Amphymenium amphistylium & & 7.55 & 7.9 & 8.6 \\
\hline LO & Cyrtocapsella tetrapera & & & 9.5 & 10.9 \\
\hline LO & Eucyrtidium inflatum & & & 11.9 & 10.9 \\
\hline FO & L. nipponica nipponica & & & 12.6 & 15.7 \\
\hline FO & Stichocorys delmontensis & & & 13.2 & 14.9 \\
\hline LO & Eucyrtidium asanoi & & & 13.7 & 14.9 \\
\hline FO & Lithopera renzae & & & 14.9 & 16.9 \\
\hline
\end{tabular}

Notes: Time scale used is Cande and Kent (1992). LO = last occurrence, and FO = first occurrence. 
Distinguishing characters. This species is distinctive in that it is relatively long compared to its width. The arms, unlike those of A. splendiarmatum, are chambered.

Remarks. The relationship between this species and Amphymenium splendiarmatum Clark and Campbell (1942, p. 46, pl. 1, figs. 12, 14) is not clear. The principal difference noted by Clark and Campbell is that A. splendiarmatum lacks distinct chambering on the arms. A. splendiarmatum has been reported primarily in Paleogene sediments, although Nishimura (1987) records a similar form from the middle Miocene that also apparently lacks chambers on the arms. Until the relationship between these forms is understood, we prefer to retain the specific name amphistylium for the North Pacific Miocene form. Petrushevskaya and Kozlova (1972) placed the genus Amphy. menium in synonymy with Ommatocampe Ehrenberg, but subsequent authors have not followed this suggestion.

\section{Cenosphaera sp.}

(Pl. 1, Fig. 2)

Description and dimensions. Simple thick-walled spherical shell with a rough surface and closely spaced circular pores, $7-9$ on a half equator; shell diameter $=145-185 \mu \mathrm{m}$

Remarks. This species is abundant in the lowermost samples of Sites 884 and 887. Its abundance in these samples may be a local result of dissolution of more delicate forms. However, because its LO in both sites is at approximately the same level, we have retained it as a potentially useful stratigraphic biomarker.

\section{Corythospyris? sp.}

$$
\text { (PI. 2, Fig. 8) }
$$

Acanthodesmid sp. Ling, 1973, p. 780, pl. 2, fig. 1

Description. Robust bilocular cephalis with a slight sagittal constriction dividing the two halves. Pores irregular in size, shape, and arrangement, separated by thick, sometimes ridged, lattice bars. Some pores may have small, inwardly directed thorns. Prominent tubercules at junctions of lattice bars and junction of lattice bars and basal ring. Number of lattice bars joining the sagittal and basal rings is variable. Secondary laterals absent; no apical horn, but a thornlike vertical spine may be seen on some specimens. Six stout, cylindrical basal spines project downward from the basal ring: four are aligned with the sternal, frontal, and primary lateral spines; and two originate between the frontal and primary lateral spines. These spines are joined distally by horizontal bars so as to form six large pores. Additional skeletal growth is irregular and produces a characteristic "cagelike" meshwork up to $73 \mu \mathrm{m}$ in length. Termination always ragged.

Dimensions (based on 20 specimens). Maximum breadth of cephalis = $80-108 \mu \mathrm{m}$, maximum height of cephalis $=50-70 \mu \mathrm{m}$, maximum length of "thorax" $=50-73 \mu \mathrm{m}$.

Remarks. This form is clearly the same as that illustrated by Ling (1973), although he states that there are only five basal spines. Based on the above description, this species does not fit all the specifics of any genus as currently defined. It comes closest to matching the characteristics set forth for the genus Corythospyris, however, it might also be placed within the genus Phormospy. ris.

\section{Cycladophora pliocenica (Hays)}

$$
\text { (Pl. 4, Fig. 1) }
$$

Clathrocyclas bicornis Hays, 1965, p. 179, pl. 3, fig. 3

Cycladophora pliocenica (Hays) n. comb., Lombari and Lazarus, 1988, p. 104 Cycladophora bicornis Hays, Sakai, 1980, p. 709, pl. 6, figs. 9a-11b Clathrocyclas spp., Kling, 1973, pl. 3, figs. 19, 20, 22 (only)

Remarks. The apparent North Pacific equivalent of this species is similar to that described by Hays (1965) in the Antarctic, but it is smaller and the lower part of the thorax is not so straight-sided as in Hays's illustration. The dimensions given by Hays (1965) are as follows: length of apical horn $=15-40$ $\mu \mathrm{m}$, length of cephalis $=15-30 \mu \mathrm{m}$, length of thorax $=80-150 \mu \mathrm{m}$, width of cephalis $=20-37 \mu \mathrm{m}$, width of thorax $=115-140 \mu \mathrm{m}$. In our North Pacific material, the dimensions are as follows: length of apical horn $=8-55 \mu \mathrm{m}$ (usually 8-32 $\mu \mathrm{m}$ ), length of cephalis $=10-18 \mu \mathrm{m}$, length of thorax $=60-105 \mu \mathrm{m}$, maximum width of cephalis $=18-28 \mu \mathrm{m}$, maximum width of thorax $=78-100$ $\mu \mathrm{m}$.

\section{Dictyophimus bullatus Morley and Nigrini $\mathrm{n} . \mathrm{sp}$.}

(Pl. 4, Figs. 5, 9, 10)

Description. Three-segmented shell with three prominent wings. Cephalis hemispherical with small circular pores or infilled pits. Apical and vertical spines project as two short, pointed horns. Collar stricture indistinct. Thorax inflated conical to onion shaped with subcircular to subangular pores increasing in size distally, 7 to 12 on a half equator at its maximum width. Thoracic surface sometimes thorny. Indistinct thoracic ribs become external just above the termination of the thorax to form divergent, cylindrical wings, up to $95 \mu \mathrm{m}$ in length (usually up to $50 \mu \mathrm{m}$ ). Distally, thorax somewhat constricted with a smooth peristome or, in some specimens, there is an irregular cylindrical or tapering distally abdomen. Abdominal pores irregular in size, shape and arrangement. The degree of silicification that affects pore size and wall thickness is highly variable in our North Pacific samples.

Etymology. Named for inflated nature of its thorax, bullatus, Latin, meaning inflated.

Holotype. Pl. 4, Fig. 9, Sample 145-885A-3H-CC, Q10/2, USNM 483757

Paratype. Pl. 4, Fig. 5, Sample 145-885A-3H-CC, R9/0, USNM 483758

Dimensions (based on 20 specimens). Length of cephalis $=15-22 \mu \mathrm{m}$, length of thorax $=75-130 \mu \mathrm{m}$, length of abdomen $=$ up to $50 \mu \mathrm{m}$, maximum breadth of cephalis $=24-32 \mu \mathrm{m}$, maximum breath of thorax $=100-135 \mu \mathrm{m}$.

Distinguishing characters. This species is distinguished from other members of the genus by its inflated rather than conical thorax.

Dictyophimus splendens (Campbell and Clark) emend. Morley and Nigrini (Pl. 7, Figs. 3, 4)

Pterocorys (Pterocyrtidium) splendens Campbell and Clark, 1944, p. 46, pl. 6, figs. 19,20

Dictyophimus splendens (Campbell and Clark) n. comb., Caulet, 1986a, p. 852

Description. Cephalis hemispherical, poreless, hyaline. Inside the cephalis both the apical and vertical spines are free of the shell wall. Externally the apical spine is prolonged into an unusually long cylindrical horn tapering to a point distally. In our North Pacific material, the horn is up to four times as long as the cephalothorax, but in tropical material it may be even longer. Campbell and Clark's (1944) original description described the horn as "sinuous," but it may also be straight or curved. Collar stricture indistinct. Thorax conical, thickwalled, sometimes thorny, with subcircular pores increasing in size distally, 4 to 6 on a half equator at the base of the thorax. Indistinct thoracic ribs become external just above the termination of the thorax and are prolonged into three weakly bladed or cylindrical wings tapering to a point distally. Wings diverge freely, forming an extension of the conical line of the thorax. Thoracic termination smooth or may have irregularly placed, inwardly curving teeth or projections or other indications of the beginnings of an abdomen. Abdomen irregular, varying in state of development and having pores similar to those on the thorax. Termination ragged.

Dimensions (based on 20 specimens). Length of cephalis $=15-22 \mu \mathrm{m}$, length of thorax $=55-100 \mu \mathrm{m}$, length of abdomen $=$ up to $45 \mu \mathrm{m}$, maximum breadth of cephalis $=18-30 \mu \mathrm{m}$, maximum breadth of thorax $=65-100 \mu \mathrm{m}$, length of wings $=$ up to $65 \mu \mathrm{m}$, length of apical horn $=$ up to $275 \mu \mathrm{m}$. Campbell and Clark (1944) report a length of $370 \mu \mathrm{m}$ for the apical horn.

Distinguishing characters. The extraordinary length of the apical horn of this species distinguishes it from all others.

Remarks. It is likely that the form described by Riedel (1952, p. 7, pl. 1, fig. 2) as Pterocorys splendens Campbell and Clark albatrossensis Riedel from the western tropical Pacific is a synonym of Dictyophimus splendens, but it would be necessary to examine topotypic material to verify this synonymy.

\section{Eucyrtidium asanoi Sakai}

(Pl. 4, Figs. 6, 7)

Eucyrtidium asanoi Sakai, 1980, p. 709, pl. 7, figs. 12a-b, 13a-c, 14a-b Eucyrtidium sp. Ling, 1973, pl. 2, fig. 9

Eucyrtidium cienkowskii group, Weaver et al., 1981, pl. 1, figs. 6-8 Eucyrtidium asanoi Sakai, Funayama, 1988, pl. 3, figs. 5a-b, 7, 8, 13

Remarks. Both the truncate conical form of Sakai (1980) and Funayama (1988) and the nearly cylindrical form of Funayama (1988, pl. 3, fig. 7) cooccur in our material. 
Eucyrtidium inflatum Kling

(Pl. 4, Fig. 11)

Eucyrtidium inflatum Kling, 1973, p. 636, pl. 11, figs. 7-8; pl. 15, figs. 7-10

Remarks. The maximum breadth of specimens encountered in our material is generally greater $(85-110 \mu \mathrm{m})$ than that reported by Kling $(80-94 \mu \mathrm{m})$.

\section{Haliommetta miocenica (Campbell and Clark)} (Pl. 1, Fig. 3)

Heliosphaera miocenica, Campbell and Clark, 1944, p. 16, pl. 2, figs. 10-14 Haliommetta miocenica (Campbell and Clark) group, Petrushevskaya and Kozlova, 1972, p. 517, pl. 9, figs. 8, 9; Chen, 1975b, p. 453, pl. 20, figs. 14,15

Dimensions. Additional dimensions for this species are as follows: diameter of medullary shell $=35-50 \mu \mathrm{m}$, diameter of cortical shell $=110-130 \mu \mathrm{m}$, diameter of pores $=7-10 \mu \mathrm{m}$, length of spines $=10-80 \mu \mathrm{m}$, number of spines $=$ up to 11, and number of pores on a half equator $=11-18$.

Remarks. Although first described in Miocene sediments from California, Petrushevskaya and Kozlova (1972) and Chen (1975b) reported this species in Antarctic sediments of Pleistocene age. Caulet (1991) shows it ranging from the late Miocene to the NR2 Zone, just below the last appearance datum of Stylatractus universus, in Site 745 on the Kerguelen Pl.au. In our material from the North Pacific, H. miocenica occurs only in Pliocene to Holocene sediments.

\section{The Lychnocanium grande Problem}

The use and misuse of this species has had a long and tortuous history that may best be explained by examining its literature chronologically.

1944. Campbell and Clark described Lychnocanium grande from the California Miocene. It is a Pterocorythidae with pores on the cephalis and on the upper parts of the legs. The thorax is described as subconical. They also described a similar, but smaller subspecies called Lychnocanium grande brevis. Weaver et al. 1981 (pl. 2, figs. 4,5) rephotographed Campbell and Clark's figured specimens.

1952. Dogel and Reshetnyak described, but did not illustrate, a similar form with many cephalic pores as Lychnocanium vitiazi. As this form was not illustrated, it cannot be considered further herein.

1952. Riedel described the subspecies Lychnocanium grande rugosum in presumably Holocene (top of SDSE Core 87B) material from the western tropical Pacific. It is similar to $L$ grande but has a rougher surface and smaller thoracic pores.

1960. Kozlova, using material from northern Sakhalin, described the Miocene species Lychnocanium laesum as being similar to $L$. grande but with a rougher surface, no porous plate around the mouth, and a narrower thorax, although this last difference is not consistent with her recorded measurements. It seems likely that this species is synonymous with Lychnocanium nipponicum Nakaseko (see below).

1963. Nakaseko described Lychnocanium nipponicum from the Japanese Miocene. The only difference noted between nipponicum and grande is that the former has no pores on the cephalis. He includes in this species Lychnocanium cf. grande in Nakaseko, 1955, p. 100, pl. VIII, figs. 6, 7; Lychnocanium nipponicum in Nakaseko, 1959 and 1960; Lychnocanium a, b, and c spp. in Nakaseko, 1954

1972. Petrushevskaya and Kozlova recorded the presence of Lychnocanium grande in Oligocene to Miocene sediments from the Antarctic, but they noted that there are no pores on the cephalis.

1973. Foreman changed the generic name to Lychnocanoma.

1973. Kling recorded Lychnocanoma grande (Campbell and Clark) in Miocene sediments from the northeastern Pacific. He noted a similar form in Holocene material but was unsure how to deal with it.

1976. Kruglikova reported the occurrence of a form similar to L. grande rugosum in upper Pleistocene, but not Holocene, sediments from the North Pacific. She suggested that its LO might be a useful stratigraphic marker at about $35-40$ k.y.

1980. Sakai described the new subspecies Lychnocanoma nipponica magnacornuta from the Miocene of the North Pacific. In the taxonomy of this subspecies, he included L. nipponicum in Nakaseko and Sugano, 1973, pl. 3, fig. la-b, and Lychnocanium sp. in Ling, 1973, p. 781, pl. 2, figs. 10, 11. This subspecies is similar to L. nipponica nipponica, but has a markedly larger apical horn. Sakai also recorded the presence of Lychnocanoma nipponica nipponica in Miocene sediments, and he described, but without dimensions, Lychnocanoma sp. in Pleistocene material.
1980. Reynolds recorded $L$ grande in his North Pacific Miocene material and $L$. cf. grande in his Pleistocene material.

1985. Morley reported the presence of $L$. grande in his North Pacific material, however, according to his range charts, this is the Pleistocene form.

1985. Lazarus et al. placed Kling's (1973) Miocene $L$. sp. cf. grande, Reynolds' (1980) Pleistocene L. sp. cf. L. grande, and Sakai's (1980) Pleistocene Lychnocanoma sp. in synonymy with Pterocanium korotnevi (Dogel). We do not agree with these assignments. The cephalic structure of $P$. korotnevi is quite different and the shell much less robust.

1990. Nishimura, in disagreement with Foreman (1973), reinstated the genus Lychnocanium and placed $L$. nipponica magnacornuta in synonymy with L. nipponica nipponica, which would become Lychnocanium nipponicum again.

1992. Wang and Yang described L. nipponicum as ranging from the middle Miocene to the Quaternary, although they only record specimens in $\mathrm{Mi}$ ocene and Pliocene samples. Examination of their figured specimens from the Pliocene (pl. 5, figs. 7,8 ) suggests to us that neither specimen is $L$. nipponicum.

This paper. Our examination of material from the California Miocene has convinced us that the species described by Campbell and Clark as $L$. grande is not the same as the Miocene species we have observed in the North Pacific. Primarily, we find that the shape of the thorax is quite different and the shell wall is not as robust. We do not consider the presence or absence of pores on the cephalis to be a valid specific distinction. It is true that most of the North Pacific specimens have a poreless cephalis, although this is not always true, but we think that this reflects the degree of silicification rather than a specific difference. It is possible that there is a continuum between the North Pacific and the California forms, but we have not observed it and, therefore, have chosen not to use the specific name grande at this time. At the same time, however, we are less certain of the taxonomic position of the specimens figured by Akers et al. (1987, pl. 6, figs. 1, 2) from the upper Miocene to Pliocene Sweeny Road Section near Lompoc, California. Other references to species within this group are included in the synonymies listed below.

We have observed some forms (PI. 6, Fig. 3) transitional between $L$. nipponica nipponica and $L$. nipponica magnacornuta and agree with Nishimura (1990) that they are probably the same species. In addition, subspecies should, strictly speaking, be separated geographically. However, we have found that by recording the two forms, most of which clearly belong to one or the other subspecies, we can obtain some useful stratigraphic information. For that reason they remain separated herein. We reject, for the time being, Nishimura's reinstatement of the genus Lychnocanium until the sweeping changes proposed in her study can be evaluated as a whole.

The Pleistocene form is clearly very similar to the Miocene form, but we have not observed intermediate specimens. For this reason, we propose herein to erect a new subspecies, Lychnocanoma grande sakaii. Normally, subspecies must be separated geographically, but we have chosen herein to use the category of subspecies for forms that are separated stratigraphically.

Lychnocanoma nipponica (Nakaseko) sakaii Morley and Nigrini n. ssp. (PI. 6, Figs. 1, 4)

?Lychnocanium grande Campbell and Clark rugosum Riedel, 1952, p. 6 , pl. I, fig. 1

Lychnocanoma grande Campbell and Clark rugosum Riedel, Kruglikova, 1976, pl. 1, figs. 1,2

Lychnocanium sp. aff. Lychnocanoma grande rugosum, Kruglikova, 1976, pl. 1, figs. 4-6

Lychnocanoma sp., Sakai, 1980, p. 711, pl. 9, fig. 1a-b

Lychnocanoma sp. cf. L. grande (Campbell and Clark), Reynolds, 1980, p. 766 , pl. 1, figs. 21,22

Lychnocanoma grande (Campbell and Clark), Morley, 1985, p. 412, pl. 6, fig. $4 \mathrm{~A}-\mathrm{B}$

Description. Cephalis hemispherical with a few small subcircular pores or infilled pits. Apical spine free within the cephalis and prolonged into a slender cylindrical apical horn tapering distally. Base of apical horn may be threebladed. Collar stricture distinct. Thorax hemispherical, usually thick walled with a rough surface and bearing subcircular pores aligned longitudinally, 812 on a half equator. Thorax is constricted distally and terminates in a smooth, poreless peristome. From the base of the thorax arise three robust, three-bladed legs that may flare outward or curve inward; legs may have one or two proximal pores. In some specimens, there is a delicate skirt or abdomen of irregular meshwork attached to the peristome and, at least proximally, to the feet. Even when the third segment is missing, there may be small thorns on the inner margin of the feet indicating where the meshwork was attached. 
Etymology. After Toyosaburo Sakai, who first described it in the DSDP Leg 56 report in 1980.

Holotype. Pl. 6, Fig. 4, Sample 145-881C-1H-CC, M19/3, USNM 483759

Paratype. Pl. 6, Fig. 1, Sample 145-887A-2H-1, 12-13 cm, P44/0, USNM 483760

Dimensions (based on 20 specimens). Length of apical horn $=$ up to 55 $\mu \mathrm{m}$, length of cephalis $=20-30 \mu \mathrm{m}$, length of thorax $=45-65 \mu \mathrm{m}$, length of legs $=$ up to $220 \mu \mathrm{m}$; maximum breadth of cephalis $=28-40 \mu \mathrm{m}$, maximum breadth of thorax $=90-115 \mu \mathrm{m}$.

Distinguishing characters. This subspecies is essentially the same as $L$.. nipponica nipponica, but it is restricted to the latest Pliocene and Pleistocene.

\section{Lychnocanoma nipponica (Nakaseko) magnacornuta Sakai} (Pl. 5, Figs. 1, 2)

Lychnocanium nipponicum Nakaseko, 1963, p. 168, text-fig. 2, pl. 1, fig. 1ab; Nakaseko and Sugano, 1973, pl. 3, fig. 1a-b

Lychnocanium sp. Ling, 1973, p. 781, pl. 2, figs. 10, 11

Lychnocanoma nipponica (Nakaseko) magnacornuta Sakai, 1980, p. 710, pl. 9, fig. 3a-b

\section{Lychnocanoma nipponica nipponica (Nakaseko)} (Pl. 5, Figs. 4, 5)

Lychnocanium nipponicum Nakaseko, 1963, p. 168, text-fig. 2, pl. 1, fig. 1a-b Lychnocanoma grande (Campbell and Clark), Kling, 1973, p. 637, pl. 10, figs. 10-14

Lychnocanoma nipponica nipponica Sakai, 1980, p. 710, pl. 9, fig. 2a-b

Sphaeropyle langii Dreyer emend. Foreman emend. Morley and Nigrini (Pl. 2, Figs. 2, 5, 7)

Sphaeropyle langii Dreyer, 1889, p. 13, pl. 4, fig. 54; Kling, 1973, p. 634, pl. 1, figs. 5-10, pl. 13, figs. 6-8 (with synonymy); Foreman, 1975, p. 618, pl. 9 , figs. 30,31 (with synonymy)

Remarks. Foreman's updated definition of this species is emended herein to include only those forms having a maximum of 8-9 pores on the outermost medullary shell rather than $8-12$ pores.

Sphaeropyle robusta Kling emend. Foreman emend. Morley and Nigrini (PI. 1, Figs. 6, 7)

Sphaeropyle robusta Kling, 1973, p. 634, pl. 1, figs. 11, 12; pl. 6, figs. 9-13; pl. 13, figs. 1-5

Sphaeropyle robusta Kling emend. Foreman, Foreman, 1975, p. 618, pl. 9, figs. 24-26

Remarks. Foreman's emended definition of this species is emended herein to include only those forms having ten or more pores on a half-equator of the outer medullary shell.

\section{Stichocorys peregrina (Riedel)}

(Pl. 6, Figs. 2, 3)

Eucyrtidium elongatum peregrinum Riedel, 1953, p. 812, pl. 85, fig. 2 Stichocorys peregrina (Riedel), Sanfilippo and Riedel, 1970, p. 451, pl. 1, fig. 10

Remarks. Specimens in our material conform to descriptions given for high latitude forms by Sanfilippo et al. (1985).

Dimensions (based on 20 specimens). Of third and fourth segments: maximum length of third segment $=28-50 \mu \mathrm{m}$, maximum length of fourth segment $=30-50 \mu \mathrm{m}$, maximum breadth of third segment $=60-100 \mu \mathrm{m}$, maximum breadth of fourth segment $=72-105 \mu \mathrm{m}$.

Theocorys redondoensis (Campbell and Clark) emend. Morley and Nigrini (Pl. 7, Figs. 1, 2,6)

Theocyrtis redondoensis Campbell and Clark, 1944, p. 49, pl. 7, fig. 4

Theocorys redondoensis (Campbell and Clark), Kling, 1973, p. 638, pl. 11, figs. $26-28$

Remarks. The species definition is emended herein to include forms with up to six randomly placed cylindrical spines, up to $65 \mu \mathrm{m}$ in length, projecting from the thorax. Additional dimensions for this species are as follows: length of apical horn $=$ up to $60 \mu \mathrm{m}$, length of cephalis $=40-55 \mu \mathrm{m}$, length of thorax
$=60-110 \mu \mathrm{m}$, length of abdomen $=$ up to $65 \mu \mathrm{m}$, maximum breadth of cephalis $=35-50 \mu \mathrm{m}$, maximum breadth of thorax $=90-120 \mu \mathrm{m}$, number of pores on a half equator of thorax at the widest point $=7-10$. These measurements are in good agreement with those originally given by Campbell and Clark (1944).

$$
\text { Gen. et sp. indet. }
$$

$$
\text { (PI. 1, Fig. 1) }
$$

Remarks. We have found the form described by Reynolds (1980, p. 761 , pl. 1, figs. 5-9) as Collosphaera pyloma. However, we do not think that this form is a collosphaerid, nor have we been able to find a satisfactory generic assignment for the taxon. It appears, nevertheless, to be a useful stratigraphic marker with its LO near the top of Riedel and Sanfilippo's Diartus petterssoni Zone. For this reason we have documented its occurrence in our North Pacific material. We have restricted our counts to those forms in which the pylome is clearly visible.

\section{Species List}

Actinomma popofskii (Petrushevskaya) (Pl. 1, Figs. 4, 5)

Echinomma popofskii Petrushevskaya, 1967, p. 23, fig. 12, I-III Actinomma popofskii (Petrushevskaya) n. comb., Caulet, 1986a, p. 851

$$
\text { Anthocyrtella (?) callopisma Caulet }
$$

$$
\text { (PI. 3, Fig. 3) }
$$

?Anthocyrtella sp. A, Petrushevskaya, 1975, p. 587, pl. 15, fig. 2, pl. 16, fig. 5 Anthocyrtella (?) callopisma Caulet, 1986b, p. 227, pl. 1, figs. 1,2

\section{Botryostrobus aquilonaris (Bailey)}

(PI. 6, Fig. 7)

Eucyrtidium aquilonaris Bailey, 1856, p. 4, pl. 1, fig. 9

Botryostrobus aquilonaris (Bailey), Nigrini, 1977, p. 246, pl. 1, fig. 1 (with synonymy)

\section{Cycladophora cosma cosma Lombari and Lazarus}

$$
\text { (Pl. 4, Fig. 2) }
$$

Cycladophora davisiana (Ehrenberg) var. cornutoides Petrushevskaya, 1967. p. 126, fig. 70, I-III

Cycladophora cosma cosma Lombari and Lazarus, 1988, p. 104, pl. 1, figs. 1-6 (with synonymy)

\section{Cycladophora davisiana davisiana (Ehrenberg)}

(Pl. 4, Figs. 3, 4)

Cycladophora (?) davisiana Ehrenberg, 1861, p. 297; 1873, pl. 2, fig. 11 Theocalyptra davisiana (Ehrenberg), Riedel, 1958, p. 239, pl. 4, figs. 2, 3, text-fig. 10 (with synonymy)

Cycladophora davisiana Ehrenberg, Petrushevskaya, 1967, p. 122, fig. 69, IVII

$$
\text { Cyrtocapsella cornuta (Haeckel) }
$$$$
\text { (PI. 3, Fig. 8) }
$$

Cyrtocapsa (Cyrtocapsella) cornuta Haeckel, 1887, p. 1513, pl. 78, fig. 9 Cyrtocapsella cornuta (Haeckel), Sanfilippo and Riedel, 1970, p. 453, pl. 1, figs. 19, 20 (with synonymy)

$$
\text { Cyrtocapsella japonica (Nakaseko) }
$$

Eusyringium japonicum Nakaseko, 1963, p. 193, text-figs. 20, 21, pl. 4, figs. $1-3$

Cyrtocapsella japonica (Nakaseko), Sanfilippo and Riedel, 1970, p. 452, pl. 1, figs. 13-15 (with synonymy)

$$
\text { Cyrtocapsella tetrapera (Haeckel) }
$$

(PI. 3, Fig. 6) 
Cyrtocapsa (Cyrtocapsella) tetrapera Haeckel, 1887, p. 1512, pl. 78, fig. 5

Cyrtocapsella tetrapera (Haeckel), Sanfilippo and Riedel, 1970, p. 453, pl. 1, figs. 16-18 (with synonymy)

\section{Didymocyrtis tetrathalamus (Haeckel}

(PI. 2, Fig. 6)

Panartus tetrathalamus Haeckel, 1887, p. 378, pl. 40, fig. 3

Didymocyrtis tetrathalamus (Haeckel), Sanfilippo and Riedel, 1980, p. 1010

\section{Eucyrtidium calvertense Martin}

(Pl. 4, Fig. 8)

Eucyrtidium calvertense Martin, 1904, p. 450, pl. 130, fig. 5; Hays, 1965, p. 181, pl. III, fig. 6

\section{Eucyrtidium matuyamai Hays}

(PL. 5, Fig. 3)

Eucyrtidium mattyamai Hays, 1970, p. 213, pl. 1, figs. 7-9

\section{Lamprocyrtis heteroporos (Hays)}

(PI. 7, Figs. 5, 8)

Lamprocyclas heteroporos Hays, 1965, p. 179, pl. 3, fig. 1

Lamprocyrtis heteroporos (Hays), Kling, 1973, p. 639, pl. 5, figs. 19-21; pl. 15, fig. 6

Lamprocyrtis neoheteroporos Kling

(PI. 7, Fig. 7)

Lamprocyrtis neoheteroporos Kling, 1973, p. 639, pl. 5, figs. 17, 18; pl. 15, figs. 4,5

Lamprocyrtis nigriniae (Caulet)

(PI. 7, Fig. 9)

Conarachnium? sp. Nigrini, 1968, p. 56, pl. 1, fig. 5a-b

Conarachnium nigriniae Caulet, 1971, p. 3, pl. 3, figs. 1-4; pl. 4, figs. 1-4

Lamprocyrtis haysi Kling, 1973, p. 639, pl. 5, figs. 15, 16; pl. 15, figs. 1-3

Lamprocyrtis nigriniae (Caulet), Kling, 1977, p. 217, pl. 1, fig. 17

Lithopera (Lithopera) renzae Sanfilippo and Riedel

$$
\text { (Pl. 3, Fig. 5) }
$$

Lithopera (Lithopera) renzae Sanfilippo and Riedel, 1970, p. 454, pl. 1, figs. $21-23,27$

Phormostichoartus crustula (Caulet)

(PI. 6, Fig. 8)

Lithamphora crustula Caulet, 1979, p. 131, pl. 2, fig. 1

Phormostichoartus crustula (Caulet), Nigrini and Caulet, 1992, p. 161, pl. 6, figs. $10-14$

\section{Phormostichoartus fistula Nigrini}

(PI. 6, Fig. 6)

Phormostichoartus fistula Nigrini, 1977, p. 253, pl. 1, figs, 11-13

Phormostichoartus pitomorphus Caulet

(Pl. 6, Fig. 9)

Phormostichoartus pitomorphus Caulet, 1986a, p. 850, pl. 3, figs. 3, 4, 9, 10, and 12

\section{Prunopyle hayesi Chen}

(Pl. 2, Figs. 1, 4)

Prunopyle hayesi Chen, 1975b, p. 454, pl. 9, figs. 3-5; Chen, 1975a, p. 482, pl. 1, figs. 7, 8, pl. 2, figs. 1, 2 non Prunopyle hayesi Chen, Weaver, 1976, p. 578, pl. 7, figs. 1-3

\section{Stichocorys delmontensis (Campbell and Clark)}

$$
\text { (PI. 6, Fig. 5) }
$$

Eucyrtidium delmontense Campbell and Clark, 1944, p. 56, pl. 7, figs. 19, 20 Stichocorys delmontensis (Campbell and Clark), Sanfilippo and Riedel, 1970, p. 451 , pl. 1, fig. 9 (with synonymy)

\section{Stylacontarium acquilonium (Hays)}

(Pl. 3, Figs. 1, 2, 4)

Druppatractus acquilonius Hays, 1970, p. 214, pl. 1, figs. 4, 5

Stylacontarium acquilonium (Hays), Kling, 1973, p. 634, pl. 1, figs. 17-20, pl. 14 , figs. $1-4$

Stylatractus universus Hays [= Axoprunum angelinum (Campbell and Clark)] (Pl. 2, Fig. 3)

Stylatractus sp. Hays, 1965, p. 167, pl. 1, fig. 6

Stylatractus universus Hays, 1970, p. 215, pl. 1, figs. 1, 2

\section{ACKNOWLEDGMENTS}

Many people provided various amounts of information, and their efforts are most appreciated by the authors. We particularly thank J.P. Caulet, S. Kling, T.C. Moore, A. Sanfilippo, and V. Shilov for informative taxonomic discussions. R. Weeks, A. Roberts, J. Barron, and T.C. Moore assisted us with time-scale problems. I. Basov, K. Bjorklund, H.-Y. Ling, and J.-P. Caulet reviewed the manuscript and their comments have improved its quality and clarity. Help from A. Nigrini, C. Heusser, and L. Heusser in various stages of manuscript preparation was instrumental in meeting deadlines. We are grateful to D. Rea, I. Basov, T. Janecek, and the other scientists and crew members of Leg 145 of the JOIDES Resolution for their support and prompt attention to our requests. Funds for the post-cruise portion of this project provided by USSAC. Samples provided by the Ocean Drilling Program.

\section{REFERENCES*}

Akers, W.H., Marolt, R.E., and Navarette, R.J., 1987. Late Miocene and early Pliocene siliceous microfossils from the upper Monterey and lower Sisquoc formations, Sweeny Road, Santa Barbara County, California. Tulane Stud. Geol. Paleontol., 20:1-112.

Alexandrovich, J.M., 1992. Radiolarians from Sites 794, 795, 796, and 797 (Japan Sea). In Pisciotto, K.A., Ingle, J.C., Jr., von Breymann, M.T., Barron, J., et al., Proc. ODP, Sci. Results, $127 / 128$ (Pt. 1): College Station, TX (Ocean Drilling Program), 291-307.

Bailey, J.W., 1856. Notice of microscopic forms found in the soundings of the Sea of Kamtschatka?with a plate. Am. J. Sci Arts, Ser. 2, 22:1-6.

Campbell, A.S., and Clark, B.L., 1944. Miocene radiolarian faunas from Southern California. Spec. Pap.?Geol. Soc. Am., 51:1-76.

Cande, S.C., and Kent, D.V., 1992. A new geomagnetic polarity time scale for the Late Cretaceous and Cenozoic. J. Geophys. Res., 97:1391713951.

Caulet, J.-P., 1971. Contribution a l'étude de quelques Radiolaries Nassellaires des boues de la Méditerranée et du Pacifique (Study of some nassellarian Radiolaria from Mediterranean and Pacific sediments). Archives originale, Centre de Documentation, C.N.R.S., No. 498. Cah. Micropaleontol., Ser. 2, 10:1-10.

-, 1979. Les depots a radiolaires d'age Pliocene superieur a Pleistocene dans l'ocean Indien central: nouvelle zonation biostratigraphique (Radiolarian upper Pliocene-Pleistocene deposits in the central Indian Ocean; new biostratigraphic zonation). Mem. Mus. Nat. Hist. Nat. Ser. C, 43:119-141.

\footnotetext{
Abbreviations for names of organizations and publications in ODP reference lists follow the style given in Chemical Abstracts Service Source Index (published by American Chemical Society).
} 
, 1986a. Radiolarians from the southwest Pacific. In Kennett, J.P., von der Borch, C.C., et al., Init. Repts. DSDP, 90: Washington (U.S. Govt. Printing Office), 835-861

,1986b. A refined radiolarian biostratigraphy for the Pleistocene of the temperate Indian Ocean. Mar. Micropaleontol., 11:217-229.

, 1991. Radiolarians from the Kerguelen Plateau, Leg 119. In Barron, J., Larsen, B., et al., Proc. ODP, Sci. Results, 119: College Station, TX (Ocean Drilling Program), 513-546.

Caulet, J.-P., Nigrini, C. and Schneider, D.A., 1993. High resolution Pliocene-Pleistocene radiolarian stratigraphy of the tropical Indian Ocean. Mar. Micropaleontol., 22:111-129.

Chen, P.-H., 1975a. Some new Tertiary radiolaria from Antarctic deep-sea sediments. Micropaleontology, 20:480-492.

1975b. Antarctic radiolaria. In Hayes, D.E., Frakes, L.A., et al., Init. Repts. DSDP, 28: Washington (U.S. Govt. Printing Office), 437513.

Clark, B.L., and Campbell, A.S., 1942. Eocene radiolarian faunas from the Mt. Diablo area, California. Spec. Pap.?Geol. Soc. Am., 39:1-112.

Dogel, V.A., and Reshetnyak, V.V., 1952. Materialy po radiolyaryam severozapadnoi chasti Tikhogo okeana (Material on radiolarians of the northwestern part of the Pacific Ocean). Issled. Dal'nevost. Morei SSSR, $3: 5-36$.

Dreyer, F., 1889. Morphologische Radiolarienstudien. 1. Die Pylombildungen in vergleichend-anatomischer und entwicklungs geschichtlicher Beziehung bei Radiolarien und bei Protisten überhaupt, nebst System und Beschreibung neuer und der bis jetzt bekannten pylomatischen Spumellarien. Jena. Z. Naturwiss., 23:1-138.

Ehrenberg, C.G., 1861. Über die Tiefgrund-Verhaltnisse des Oceans am Eingange der Davisstrasse und bei Island. K. Preuss. Akad. Wiss. Berlin Monatsberichte, Jahre 1861:275-315.

, 1873. Grössere Felsproben des Polycystinen-Mergels von Barbados mit weiteren Erläuterungen. K. Preuss. Akad. Wiss. Berlin, Monatsberichte, Jahre 1873:213-263.

Foreman, H.P., 1973. Radiolaria from DSDP Leg 20. In Heezen, B.C., MacGregor, I.D., et al., Init. Repts. DSDP, 20: Washington (U.S. Govt. Printing Office), 249-305.

, 1975. Radiolaria from the North Pacific, Deep Sea Drilling Project, Leg 32. In Larson, R.L., Moberly, R., et al., Init. Repts. DSDP. 32: Washington (U.S. Govt. Printing Office), 579-676.

Funayama, M., 1988. Miocene radiolarian stratigraphy of the Suzu area, northeastern part of the Noto Peninsula, Japan. Contrib. Inst. Geol. Paleontol. Tohoku Univ., 91:15-41. (in Japanese)

Haeckel, E., 1887. Report on the Radiolaria collected by H.M.S. Challenger during the years 1873-1876. Rep. Sci. Results Voy. H.M.S. Challenger, 1873-1876, Zool., 18:1-1803.

Hays, J.D., 1965. Radiolaria and late Tertiary and Quaternary history of Antarctic seas. In Llano, G.A. (Ed.), Biology of the Antarctic Seas II. Am. Geophys. Union, Antarct. Res. Ser., 5:125-184.

1970. Stratigraphy and evolutionary trends of radiolaria in North Pacific deep sea sediments. In Hays, J.D. (Ed.), Geological Investigations of the North Pacific. Mem.?Geol. Soc. Am., 126:185-218.

Hays, J.D., and Shackleton, N.J., 1976. Globally synchronous extinction of the radiolarian Stylatractus universus, Geology, 4:649-652.

Johnson, D.A., Schneider, D.A., Nigrini, C.A., Caulet, J.-P., and Kent, D.V., 1989. Pliocene-Pleistocene radiolarian events and magnetostratigraphic calibrations for the tropical Indian Ocean. Mar. Micropaleontol., 14:3366.

Kellogg, D.E., and Hays, J.D., 1975. Microevolutionary patterns in late Cenozoic Radiolaria. Paleobiology, 1:150-160.

Kling, S.A., 1973. Radiolaria from the eastern North Pacific, Deep Sea Drilling Project, Leg 18. In Kulm, L.D., von Huene, R., et al., Init. Repts. DSDP, 18: Washington (U.S. Govt. Printing Office), 617-671.

1977. Local and regional imprints on radiolarian assemblages from California coastal basin sediments. Mar. Micropaleontol., 2:207221.

Kozlova, G.E., 1960. Radiolyarii srednego i verkhnego miotsena Severnogo Sakhalina (Radiolarians of the middle and upper Miocene of Northern Sakhalin). Trudy Vsesoyuznogo Neftyanogo Nauchno-issledovatelskogo Geologorazvedochnogo Instituta (VNIGRI) (Proceedings of the AllUnion Petroleum Scientific Research Institute for Geological Survey), $153: 307-325$,

Kruglikova, S.B., 1976. Radiolyarii v verkhnepleistotsenovykh osadkakh borealnoi i severnoi subtropicheskoi zon (Radiolarians in the upper Pleis- tocene sediments of the boreal and northern subtropical zones of the Pacific Ocean). Okeanologiya (Oceanology), 16:113-117.

Lazarus, D.B., Scherer, R.P., and Prothero, D.R., 1985. Evolution of the radiolarian species-complex Pterocanium: a preliminary survey. J. Paleontol., 59:183-220.

Ling, H.Y., 1973. Radiolaria: Leg 19 of the Deep Sea Drilling Project. In Creager, J.S., Scholl, D.W., et al., Init. Repts. DSDP, 19: Washington (U.S. Govt. Printing Office), 777-797.

1980. Radiolarians from the Emperor Seamounts of the Northwest Pacific, Leg 55 of the Deep Sea Drilling Project. In Jackson, E.D., Koizumi, I., et al., Init. Repts. DSDP, 55: Washington (U.S. Govt. Printing Office), 365-373.

Lombari, G., and Lazarus, D.B., 1988. Neogene cycladophorid radiolarians from the North Atlantic, Antarctic, and North Pacific deep-sea sediments. Micropaleontology, 34:97-135.

Martin, G.C., 1904. Radiolaria. In Clark, W.B., Eastman, C.R., Glenn, L.C., Bagg, R.M., Bassler, R.S., Boyer, C.S., Case, E.C., and Hollick, C.A. (Eds.), Systematic Paleontology of the Miocene Deposits of Maryland: Baltimore (Maryland Geol. Surv., Johns Hopkins Press), 447-459.

Moore, T.C., Jr., 1973. Method of randomly distributing grains for microscopic examination. J. Sediment. Petrol., 43:904-906.

, 1995. Radiolarian stratigraphy, Leg 138. In Pisias, N.G., Meyer, L.A., Janecek, T.R., Palmer-Julson, A., and van Andel, T.H. (Eds.), Proc. ODP, Sci. Results, 138: College Station, TX (Ocean Drilling Program), 191-232.

Moore, T.C., Jr., Shackleton, N.J., and Pisias, N.G., 1993. Paleoceanography and the diachrony of radiolarian events in the eastern equatorial Pacific. Paleoceanography, 8:567-586.

Morley, J.J., 1985. Radiolarians from the Northwest Pacific, Deep Sea Drilling Project Leg 86. In Heath, G.R., Burckle, L.H., et al., Init. Repts. DSDP, 86: Washington (U.S. Govt. Printing Office), 399-422.

Morley, J.J., Hays, J.D., and Robertson, J.H., 1982. Stratigraphic framework for the late Pleistocene in the northwestern Pacific Ocean. Deep-Sea Res., Part A, 29:1485-1499.

Morley, J.J., and Shackleton, N.J., 1978. Extension of the radiolarian Stylatractus universus as a biostratigraphic datum to the Atlantic Ocean. Geology, 6:309-311.

Nakaseko, K., 1954. Preliminary report of Miocene radiolarian faunas from southern Toyama prefecture. Sci. Rep., Coll. Gen. Educ., Osaka Univ., 3:107-118.

1955. Miocene radiolarian fossil assemblage from the southern Tojama Prefecture in Japan. Sci. Rep., Coll. Gen. Educ., Osaka Univ., 4:65-127.

-1959 . Applied micropaleontological research by means of radiolarian fossil in the oil bearing Tertiary, Japan (mainly in Akita and Yamagata sedimentary basins): Part I. Method, geological note and radiolarian assemblage in Akita sedimentary basin. Sci. Rep., Coll. Gen. Educ., Osaka Univ., 8:113-193.

1960. Applied micropaleontological research by means of radiolarian fossil in the oil bearing Tertiary, Japan (mainly in Akita and Yamagata sedimentary basins): Part II. Radiolarian assemblage in Yamagata basin, discussion and conclusion. Sci. Rep., Coll. Gen. Educ., Osaka Univ., 9:149-185.

1963. Neogene Cyrtoidea (Radiolaria) from the Isozaki Formation in Ibaraki Prefecture, Sci. Rep., Coll. Gen. Educ. Osaka Univ., 12:165-198.

Nakaseko, K., and Sugano, K., 1973. Neogene radiolarian zonation in Japan. Chishitsugaku Ronshu [Geol. Soc. Jpn. Mem.], 8:23-33.

Nigrini, C., 1968. Radiolaria from eastern tropical Pacific sediments. Micropaleontology, 14:51-63.

, 1977. Tropical Cenozoic Artostrobiidae (Radiolaria). Micropaleontology, 23:241-269.

, 1985. Radiolarian biostratigraphy in the central equatorial Pacific, Deep Sea Drilling Project Leg 85. In Mayer, L., Theyer, F., Thomas, E., et al., Init. Repts. DSDP, 85: Washington (U.S. Govt. Printing Office), 511-551.

Nigrini, C.A., and Caulet, J.P., 1992. Late Neogene radiolarian assemblages characteristic of Indo-Pacific areas of upwelling. Micropaleontology, 38:139-164.

Nishimura, A., 1987. Cenozoic Radiolaria in the western North Atlantic, Site 603, Leg 93 of the Deep Sea Drilling Project. In van Hinte, J.E., Wise, S.W., Jr., et al., Init. Repts. DSDP, 93 (Pt. 2): Washington (U.S. Govt. Printing Office), 713-737. 
Nishimura, H., 1990. Taxonomic study on Cenozoic Nassellaria (Radiolaria). Sci. Rep. Inst. Geosci. Univ. Tsukuba, Sect. B, 11:69-172.

Petrushevskaya, M.G., 1967. Radiolyarii otryadov Spumellaria i Nassellaria antarkticheskoi oblasti (Antarctic Spumelline and Nasselline radiolarians). In Resultaty Biologicheskikh Issledovanii Sovetskoi Antarkticheskoi Ekspeditsii 1955-1958 (Vol. 3): Issled. Fauny Morei, Zool. Inst. Akad. Nauk SSSR, 4:1-186.

1975. Cenozoic radiolarians of the Antarctic, Leg 29, DSDP. In Kennett, J.P., Houtz, R.E., et al., Init. Repts. DSDP, 29: Washington (U.S. Govt. Printing Office), 541-675.

Petrushevskaya, M.G., and Kozlova, G.E., 1972. Radiolaria, Leg 14, Deep Sea Drilling Project. In Hayes, D.E., Pimm, A.C., et al., Init. Repts. DSDP, 14: Washington (U.S. Govt. Printing Office), 495-648.

Reynolds, R.A., 1980. Radiolarians from the western North Pacific, Leg 57. Deep Sea Drilling Project. In von Huene, R., Nasu, N., et al., Init. Repts. DSDP, 56, 57 (Pt. 2): Washington (U.S. Govt. Printing Office), 735-769.

Riedel, W.R., 1952. Tertiary radiolaria in western Pacific sediments. Goeteborgs K. Vetensk. Vitterhets-Samh. Handl. Sjatte Foljden, Ser. B, 6:1-22. 1953. Mesozoic and late Tertiary Radiolaria of Rotti. J. Paleontol., 27:805-813.

1958. Radiolaria in Antarctic sediments. Rep. B.A.N.Z. Antarct. Res. Exped., Ser. B, 6:217-255.

Riedel, W.R., and Sanfilippo, A., 1970. Radiolaria, Leg 4, Deep Sea Drilling Project. In Bader, R.G., Gerard, R.D., et al., Init. Repts. DSDP, 4: Washington (U.S. Govt. Printing Office), 503-575.

1971. Cenozoic Radiolaria from the western tropical Pacific, Leg 7. In Winterer, E.L., Riedel, W.R., et al., Init. Repts. DSDP. 7 (Pt. 2): Washington (U.S. Govt. Printing Office), 1529-1672.

- 1978. Stratigraphy and evolution of tropical Cenozoic radiolarians. Micropaleontology, 24:61-96.

Robertson, J.H., 1975. Glacial to interglacial oceanographic changes in the northwest Pacific, including a continuous record of the last 400,000 years [Ph.D. dissert.]. Columbia Univ., New York.

Sakai, T., 1980. Radiolarians from Sites 434, 435, and 436, Northwest Pacific, Leg 56, Deep Sea Drilling Project. In von Huene, R., Nasu, N., et al., Init. Repts. DSDP, 56, 57 (Pt. 2): Washington (U.S. Govt. Printing Office), 695-733.

Sanfilippo, A., and Riedel, W.R., 1970. Post-Eocene "closed" theoperid radiolarians. Micropaleontology, 16:446-462.

1980. A revised generic and suprageneric classification of the Artiscins (Radiolaria). J. Paleontol., 54:1008-1011.
Sanfilippo, A., Westberg-Smith, M.J., and Riedel, W.R., 1985. Cenozoic Radiolaria. In Bolli, H.M.,Saunders, J.B., and Perch-Nielson, K. (Eds.), Plankton Stratigraphy, v. 2: Cambridge (Cambridge Univ. Press), 631712 .

Schaaf, A., 1981. Late Early Cretaceous radiolarians from Deep Sea Drilling Project Leg 62. In Thiede, J., Vallier, T.L., et al., Init. Repts. DSDP, 62: Washington (U.S. Govt. Printing Office), 419-470.

Shipboard Scientific Party, 1993a. Site 884. In Rea, D.K., Basov, I.A., Janecek, T.R., Palmer-Julson, A., et al., Proc. ODP, Init. Repts., 145: College Station, TX (Ocean Drilling Program), 209-302.

, 1993b. Site 887. In Rea, D.K., Basov, I.A., Janecek, T.R., Palmer-Julson, A., et al., Proc. ODP, Init. Repts., 145: College Station, TX (Ocean Drilling Program), 335-391.

Spencer-Cervato, C., Lazarus, D.B., Beckmann, J.-P., Von Salis PerchNielsen, K., and Biolzi, M., 1993. New calibration of Neogene radiolarian events in the North Pacific. Mar. Micropaleontol., 21:261-293.

Wang, Y., and Yang, Q., 1992. Neogene and Quaternary radiolarians from Leg 125. In Fryer, P., Pearce, J.A., Stokking, L.B., et al., Proc. ODP, Sci. Results, 125: College Station, TX (Ocean Drilling Program), 95-112.

Weaver, F.M., 1976. Antarctic Radiolaria from the southeast Pacific basin, Deep Sea Drilling Project, Leg 35. In Hollister, C.D., Craddock, C., et al., Init. Repts. DSDP, 35: Washington (U.S. Govt. Printing Office), 569 603.

Weaver, F.M., Casey, R.E., and Perez, A.M., 1981. Stratigraphic and paleoceanographic significance of early Pliocene to middle Miocene radiolarian assemblages from Northern to Baja California. In Garrison, R.E., and Douglas, R.G. (Eds.), The Monterey Formation and Related Siliceous Rocks of California. Spec. Publ.?Soc. Econ. Paleontol. Mineral., Pacific Sect., 71-86.

Wolfart, R., 1981. Neogene radiolarians from the eastern North Pacific (off Alta and Baja California), Deep Sea Drilling Project Leg 63. In Yeats, R.S., Haq, B.U., et al., Init. Repts. DSDP, 63: Washington (U.S. Govt. Printing Office), 473-506.

Date of initial receipt: 5 April 1994

Date of acceptance: 31 August 1994

Ms 145SR-107 

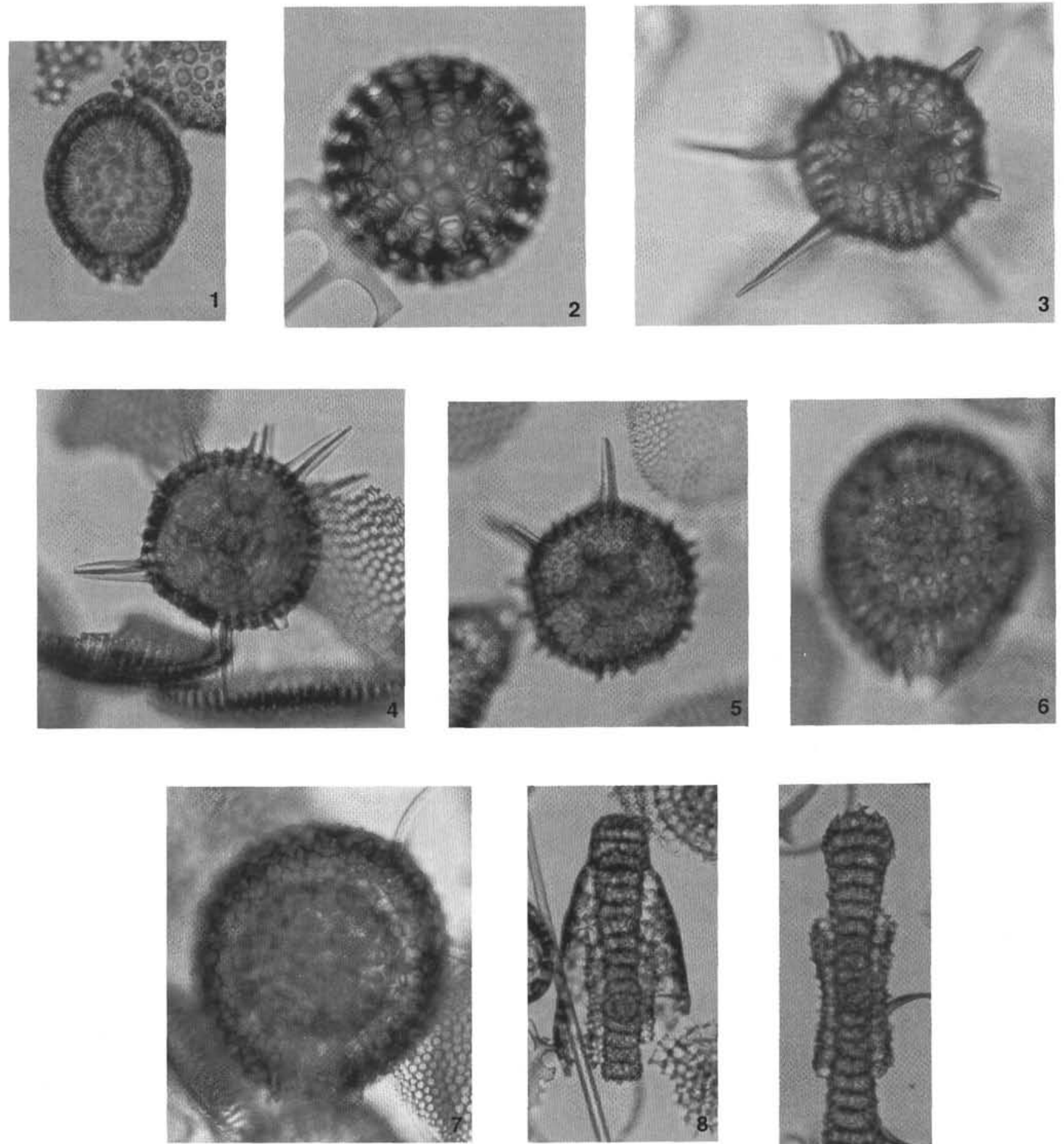

$100 \mu \mathrm{m}$

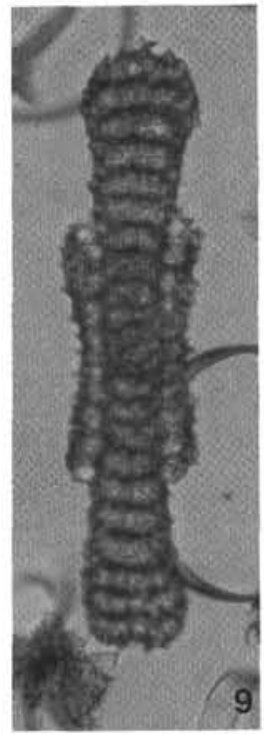

Plate 1. 1. Gen. et sp. indet., Sample 145-887A-28H-3, 54-55 cm, Q35/1. 2. Cenosphaera sp., Sample 145-884B-65X-5, 135-136 cm, V43/3. 3. Haliommetta miocenica, Sample 145-881C-1H-CC, M38/1. 4-5. Actinomma popofskii; (4) Sample 145-886C-6H-5, 114-115 cm, Q37/2; (5) Sample 145-886C-6H-5, 114$115 \mathrm{~cm}$, U35/4. 6-7. Sphaeropyle robusta; (6) Sample 145-886C-4H-CC, N9/2; (7) Sample 145-886C-6H-4, 114-115 cm, V20/1. 8-9. Amphymenium amphistylium; (8) with partial patagium, Sample 145-887A-29H-3, 54-55 cm, Y49/0; (9) Sample 145-884B-62X-5, 135-136 cm, M14/3. 

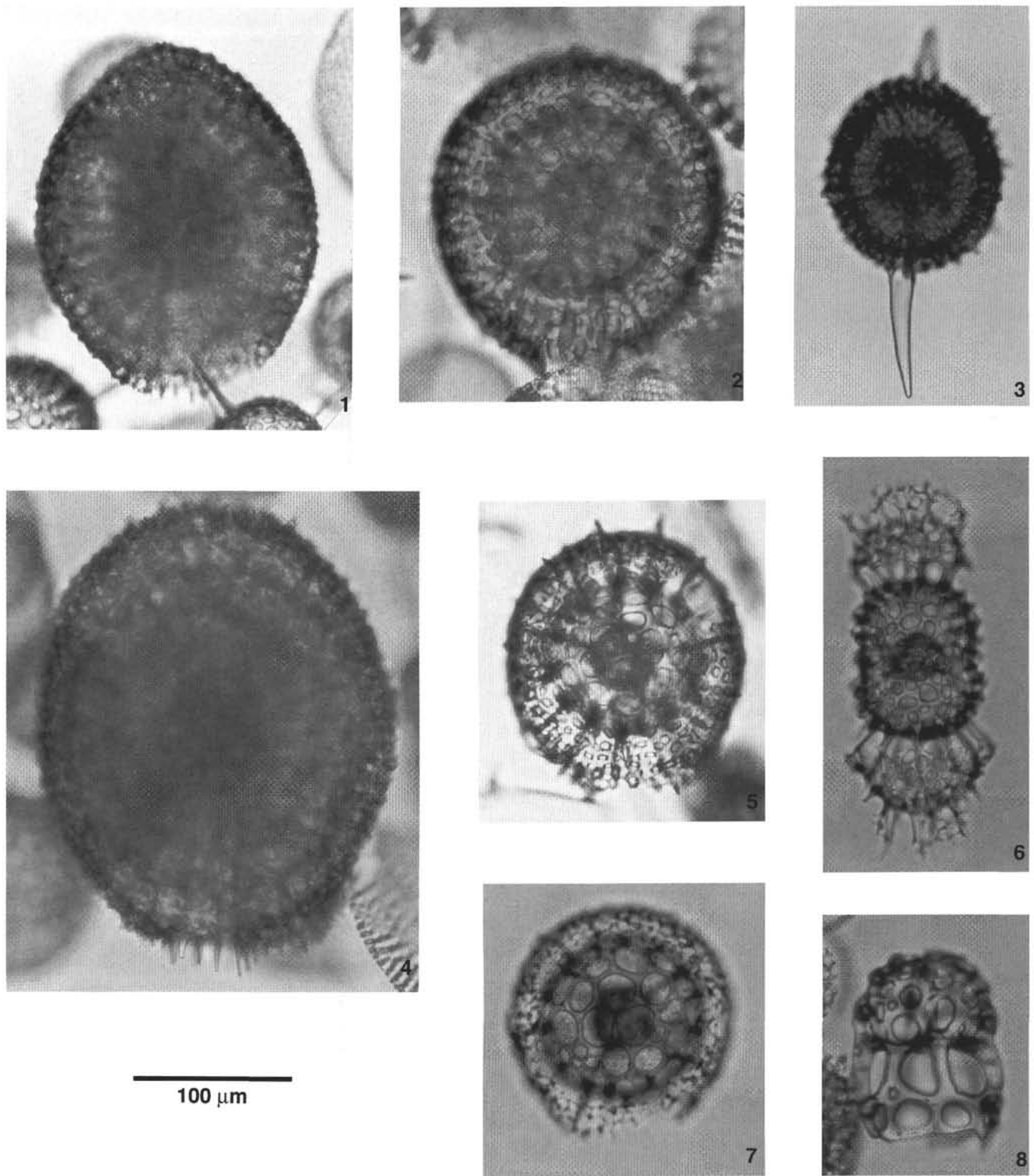

Plate 2. 1. Prunopyle hayesi, Sample 145-885A-5H-6, 115-116 cm, X41/0. 2. Sphaeropyle langii, Sample 145-886C-3H-4, 114-115 cm, R51/0. 3. Stylatractus universus, Sample 145-881C-13H-CC, P29/3. 4. Prunopyle hayesi, Sample 145-881C-36X-1, 29-30 cm, J57/3. 5. Sphaeropyle langii, Sample 145-887A-2H-1, 12-13 cm, M41/0. 6. Didymocyrtis tetrathalamus, Sample 145-881C-6H-CC, P52/1. 7. Sphaeropyle langii, Sample 145-881C-3H-3, 20-21 cm, O52/3. 8. Corythospyris? sp., Sample 145-887A-29H-3, 54-55 cm, Q5/0. 

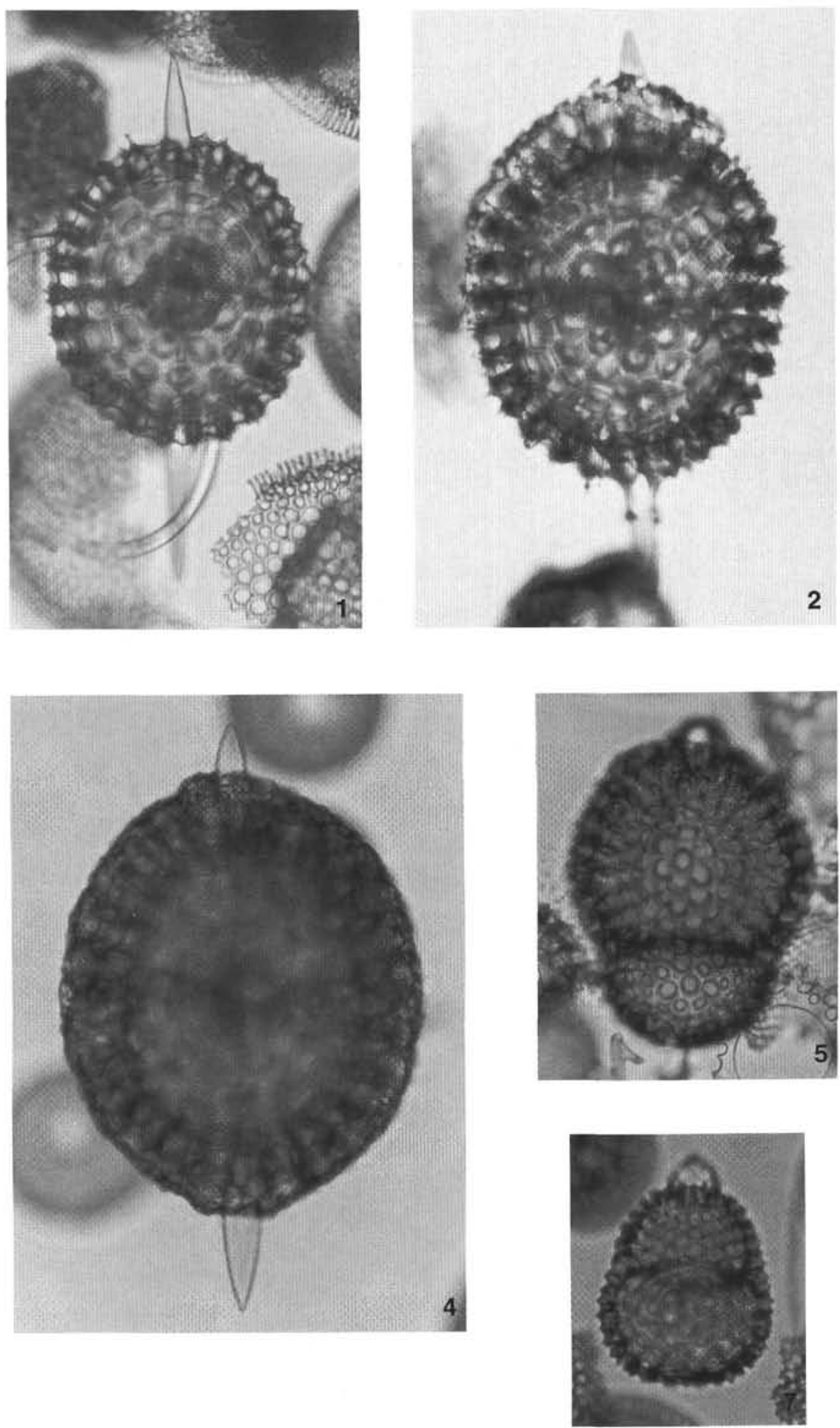

$100 \mu \mathrm{m}$
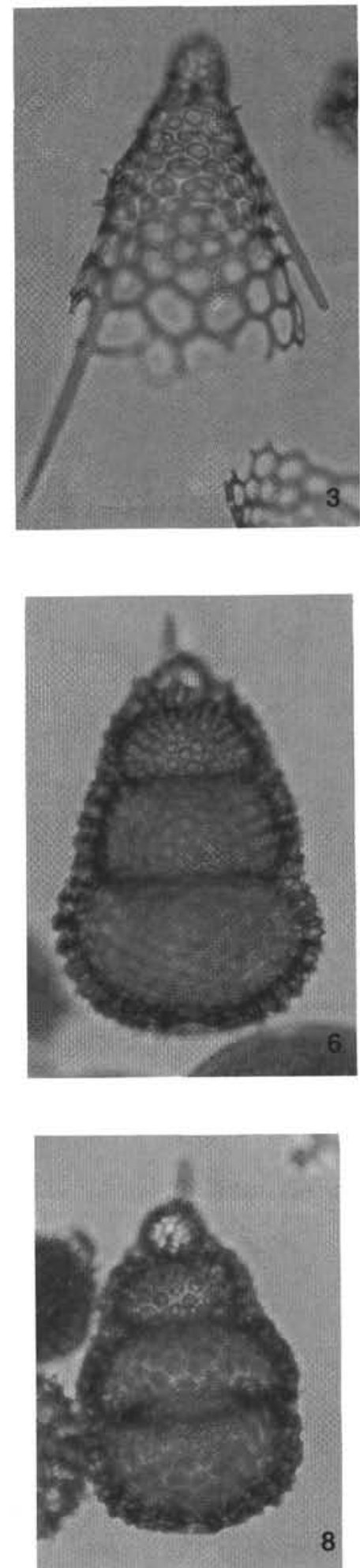

Plate 3. 1-2. Stylacontarium acquilonium; (1) Sample 145-885A-5H-5, 115-116 cm, R14/2; (2) with start of thickening of cortical shell, Sample 145-881C-6H4, 143-144 cm, Q30/0. 3. Anthocyrtella (?) callopisma, Sample 145-885A-2H-1, 115-116 cm, S12/0. 4. Stylacontarium acquilonium, with complete thickening of cortical shell, Sample 145-884B-8H-5, 135-136 cm, O6/2. 5. Lithopera renzae, Sample 145-887C-27H-3, 55-56 cm, O52/2. 6. Cyrtocapsella tetrapera, Sample 145-884B-63X-5, 135-136 cm, S30/3. 7. Cyrtocapsella japonica, Sample 145-887A-25H-3, 54-55 cm, S9/1. 8. Cyrtocapsella cornuta, Sample 145887A-28H-3, 54-55 cm, N40/0. 

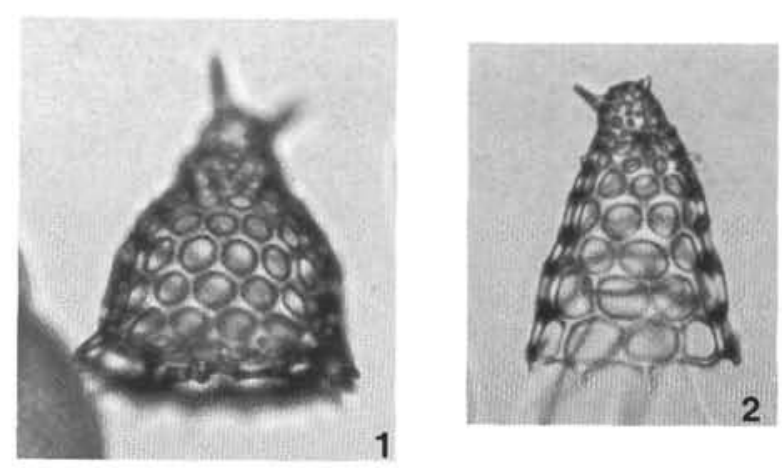

1
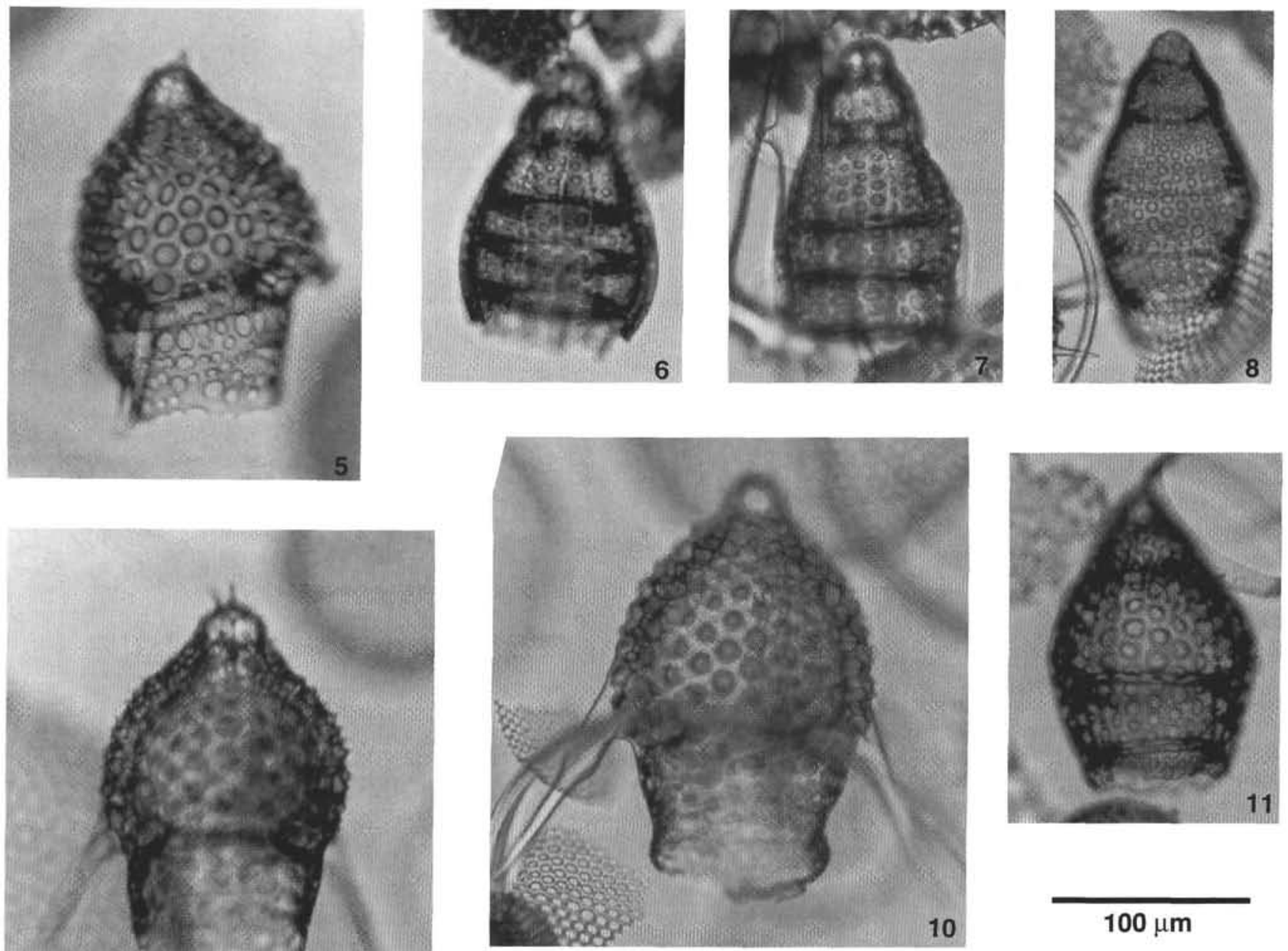

$100 \mu \mathrm{m}$

Plate 4. 1. Cycladophora pliocenica, Sample 145-887A-2H-3, 133-134 cm, M35/4. 2. Cycladophora cosma cosma, Sample 145-881B-6H-5, 111-112 cm, D57/ 2. 3-4. Cycladophora davisiana davisiana; (3) Sample 145-887A-7H-3, 54-56 cm, R41/3; (4) with beginnings of spongy mantle over upper portion of abdomen, Sample 145-887A-10H-6, 54-55 cm, O17/2. 5. Dictyophimus bullatus, Sample 145-885A-3H-CC, R9/0. 6-7. Eucyrtidium asanoi; (6) truncate conical form, Sample 145-884B-60X-CC, G46/0; (7) roughly cylindrical form, Sample 145-887A-28H-6, 55-56 cm, S10/0. 8. Eucyrtidium calvertense, Sample 145885A-3H-CC, Y34/3. 9-10. Dictyophimus bullatus; (9) holotype, Sample 145-885A-3H-CC, Q10/2; (10) Sample 145-886C-4H-CC, M34/3. 11. Eucyrtidium inflatum, Sample 145-884B-58X-5, 135-136 cm, E22/0. 

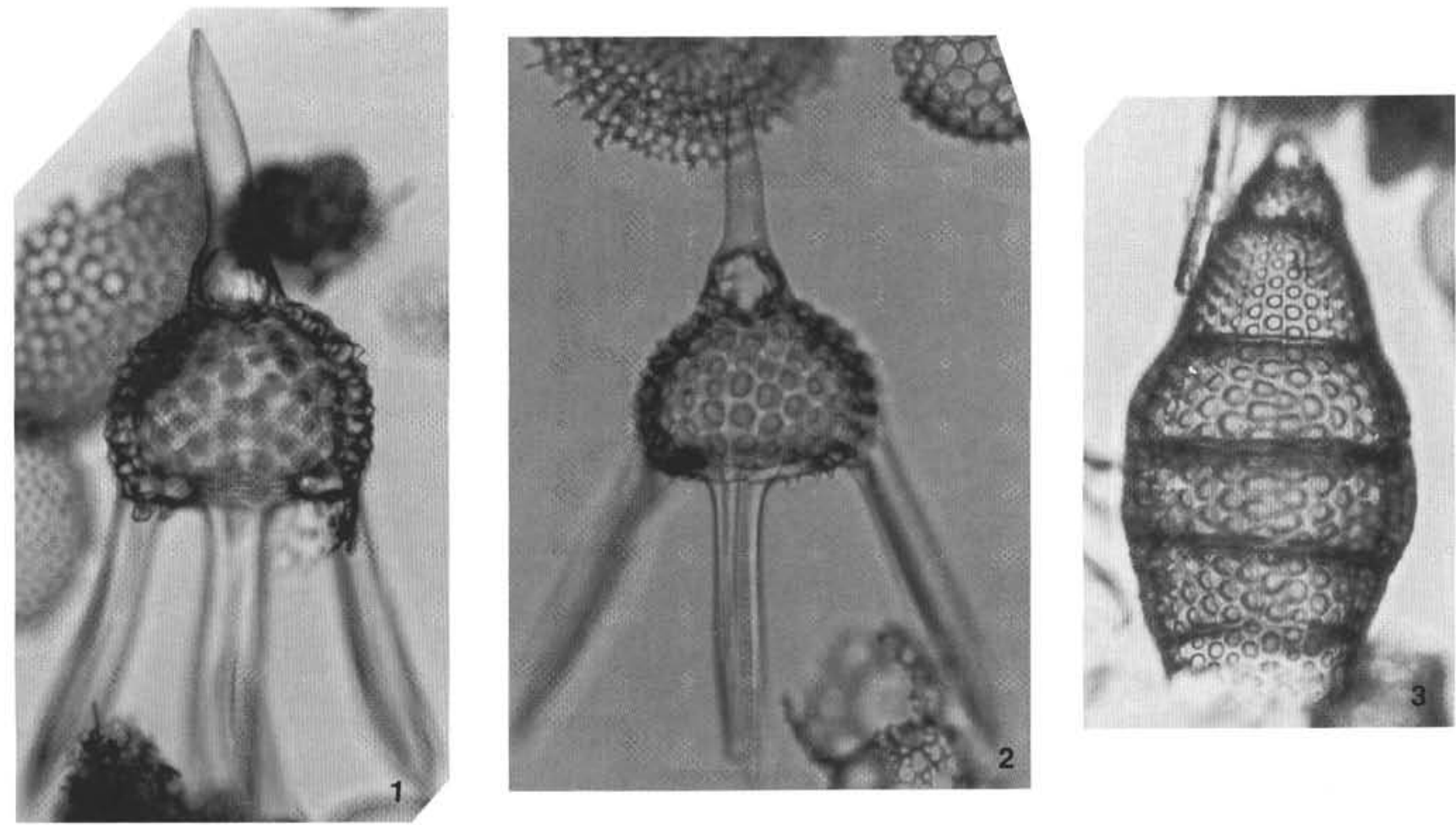

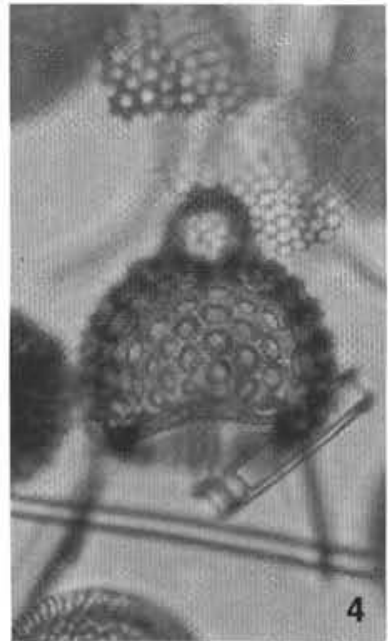

$100 \mu \mathrm{m}$
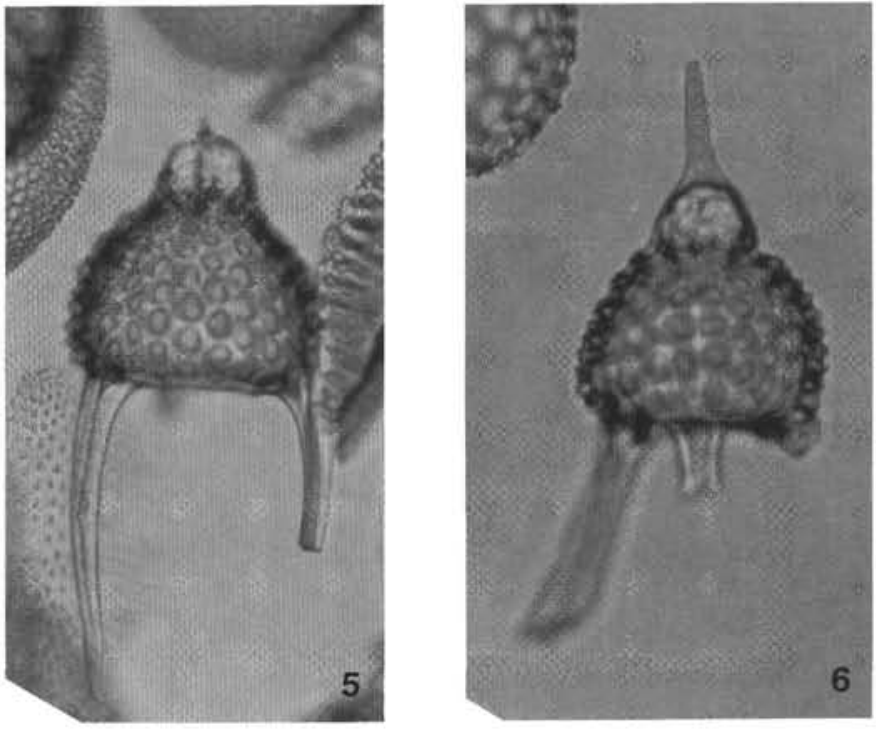

Plate 5. 1-2. Lychnocanoma nipponica magnacornuta; (1) Sample 145-883B-53X-CC, N39/0; (2)Sample 145-886C-6H-CC, K39/1. 3. Eucyrtidium matuyamai, Sample 145-887A-7H-6, 54-56 cm, P28/1. 4-5. Lychnocanoma nipponica nipponica; (4) Sample 145-884B-54X-5, 135-136 cm, T50/1; (5) Sample 145$886 \mathrm{C}-6 \mathrm{H}-5,114-115 \mathrm{~cm}, \mathrm{C} 8 / 0.6$. Intermediate form between $L$. nipponica nipponica and $L$. nipponica magnacornuta, Sample 145-886C-6H-CC, N39/0. 

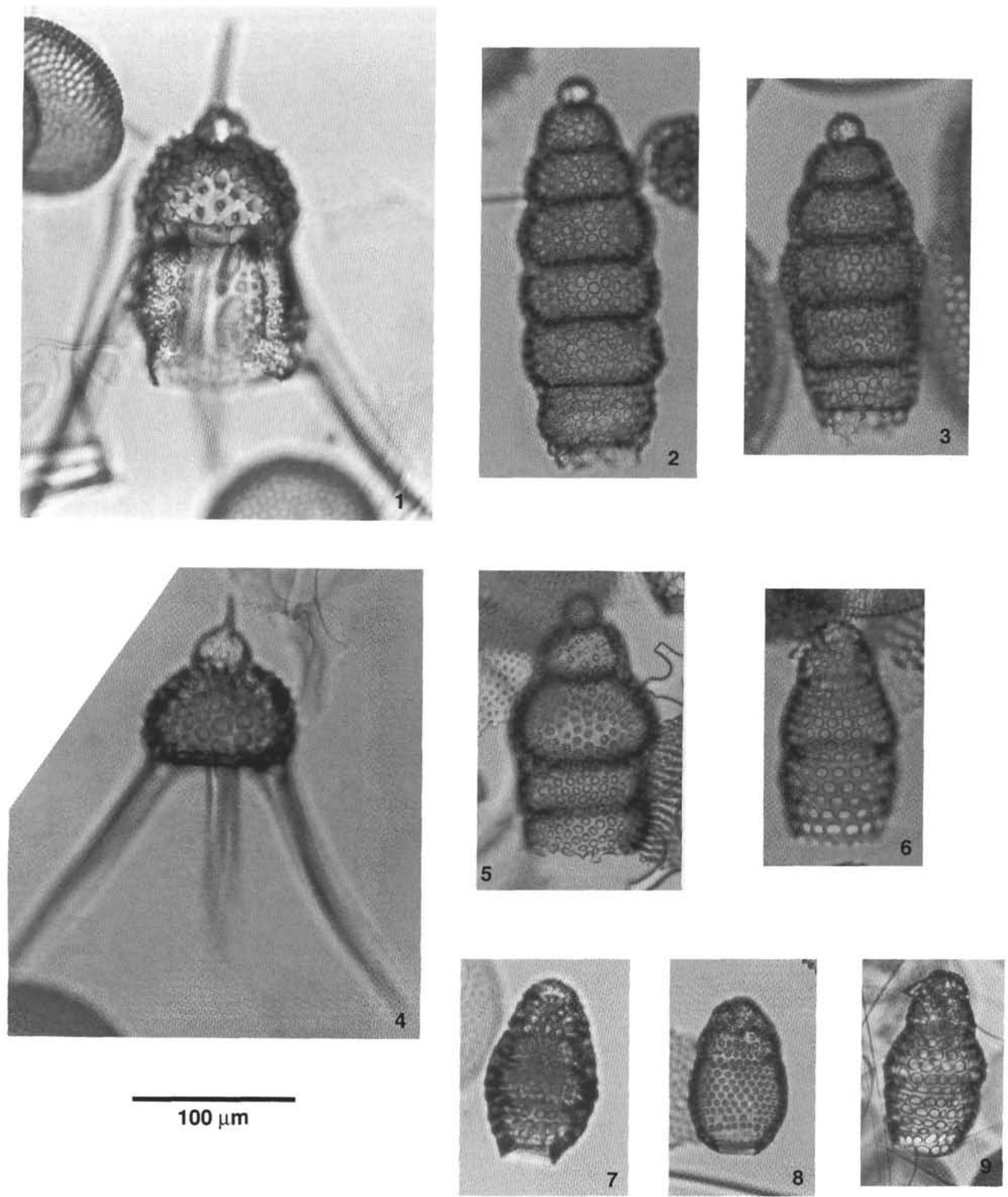

Plate 6. 1. Lychnocanoma nipponica sakaii, Sample 145-887A-2H-1, 12-13 cm, P44/0. 2-3. Stichocorys peregrina; (2) Sample 145-886C-5H-3, 98-99 cm, D30/4; (3) Sample 145-885A-5H-4, 115-116 cm, K13/2. 4. Lychnocanoma nipponica sakaii, holotype, Sample 145-881C-1H-CC, M19/3. 5. Stichocorys delmontensis, Sample 145-886C-6H-5, 114-115 cm, K30/0. 6. Phormostichoartus fistula, Sample 145-886C-6H-3, 112-113 cm, Q52/0. 7. Botryostrobus aquilonaris, Sample 145-887A-1H-1, 12-13 cm, L37/0. 8. Phormostichoartus crustula, Sample 145-885A-3H-CC, K11/3. 9. Phormostichoartus pitomorphus, Sample 145-887A-6H-6, 54-55 cm, H11/4. 

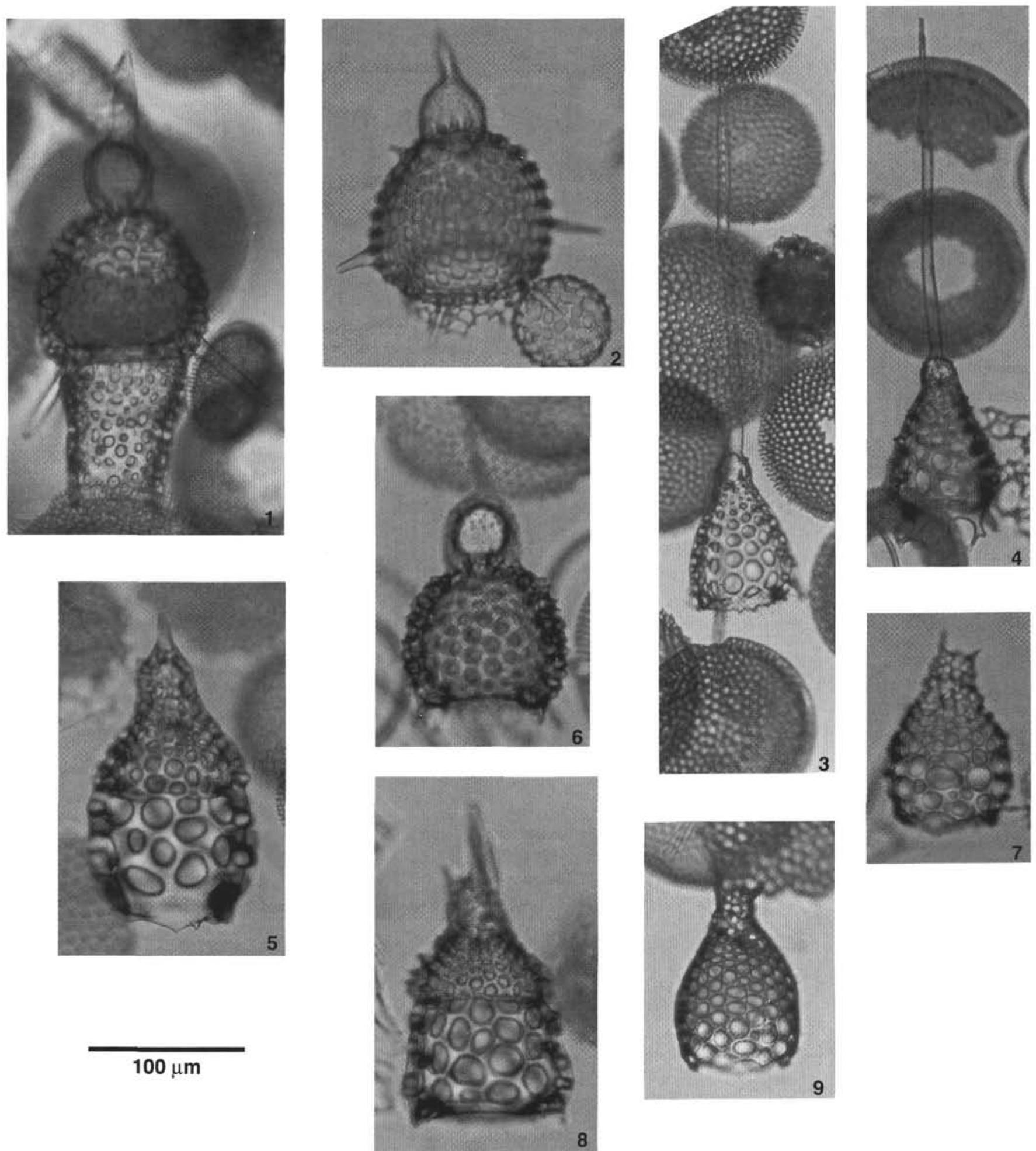

$100 \mu \mathrm{m}$

Plate 7. 1-2. Theocorys redondoensis; (1) Sample 145-884B-48X-5, 135-136 cm, L9/0; (2) Sample 145-886C-6H-CC, Y32/2. 3-4. Dictyophimus splendens; (3) Sample 145-884B-52X-5, 135-136 cm, L40/1; (4) Sample 145-884B-54X-5, 135-136 cm, S28/1. 5. Lamprocyrtis heteroporos, Sample 145-886C-3H-3, 114-115 cm, J9/1. 6. Theocorys redondoensis, Sample 145-886C-6H-2, 114-115 cm, U24/4. 7. Lamprocyrtis neoheteroporos, Sample 145-885A-2H-1, 115$116 \mathrm{~cm}, \mathrm{H} 41 / 4$. 8. Lamprocyrtis heteroporos, Sample 145-881C-18X-3, 50-51 cm, S49/2. 9. Lamprocyrtis nigriniae, Sample 145-886C-1H-3, 114-115 cm, P51/0. 